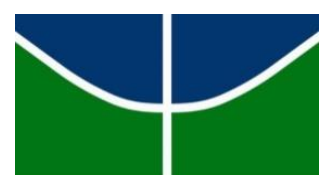

UNIVERSIDADE DE BRASÍLIA

FACULDADE DE TECNOLOGIA

DEPARTAMENTO DE ENGENHARIA FLORESTAL

PROGRAMA DE PÓS-GRADUAÇÃO EM CIÊNCIAS FLORESTAIS

\title{
ANÁLISE DOS MÉTODOS DE SENSIBILIZAÇÃO DOS PROGRAMAS DE EDUCAÇÃO AMBIENTAL DE TRÊS UNIDADES DE CONSERVAÇÃO DO DISTRITO FEDERAL
}

\section{MAYARA PARDI DE OLIVEIRA}

Orientadora: Dra. Rosana de Carvalho Cristo Martins

DISSERTAÇÃO DE MESTRADO EM CIÊNCIAS FLORESTAIS

Brasília-DF: FEVEREIRO/2016 


\section{ANÁLISE DOS MÉTODOS DE SENSIBILIZAÇÃO DOS PROGRAMAS DE EDUCAÇÃO AMBIENTAL DE TRÊS UNIDADES DE CONSERVAÇÃO DO DISTRITO} FEDERAL

\section{MAYARA PARDI DE OLIVEIRA}

DISSERTAÇÃO DE MESTRADO SUBMETIDA AO DEPARTAMENTO DE ENGENHARIA FLORESTAL DA FACULDADE DE TECNOLOGIA DA UNIVERSIDADE DE BRASÍLIA, COMO PARTE DOS REQUISITOS NECESSÁRIOS PARA OBTENÇÃO DO GRAU DE MESTRE.

APROVADA POR:

Dra. Rosana de Carvalho Cristo Martins (Departamento de Engenharia Florestal, UnB) (Orientadora)

Dra. Juliana Martins de Mesquita Matos (Faculdade de Agronomia e Veterinária, UnB) (Examinadora)

Dra. Iona’i Ossami de Moura (Ministério do Meio Ambiente)

(Examinadora) 


\section{FICHA CARTOGRÁFICA}

OLIVEIRA, MAYARA PARDI

Análise dos métodos de sensibilização dos programas de educação ambiental de três unidades de conservação do Distrito Federal [Distrito Federal] 2016.

xiii, 99p. (EFL/FT/UnB, Mestre, Dissertação de Mestrado - Universidade de Brasília. Faculdade de Tecnologia.).

Departamento de Engenharia Florestal
1. Área protegida
2. Questionário estruturado

3. Diferentes públicos-alvo

$\begin{array}{ll}\text { I. EFL/FT/UnB II. Título } & \text { In }\end{array}$

\section{REFERÊNCIA BIBLIOGRÁFICA}

Oliveira, M.P. (2016). Análise dos métodos de sensibilização dos programas de educação ambiental de três unidades de conservação do Distrito Federal. Dissertação de Mestrado em Engenharia Florestal, Publicação PPG EFL.DM-269/2016, Departamento de Engenharia Florestal, Universidade de Brasília, Brasília, DF, 99 p.

\section{CESSÃO DE DIREITOS}

AUTOR: Mayara Pardi de Oliveira.

TÍTULO: Análise dos métodos de sensibilização dos programas de educação ambiental de três unidades de conservação do Distrito Federal

GRAU: Mestre

ANO: 2016

É concedida à Universidade de Brasília permissão para reproduzir cópias desta dissertação de mestrado e para emprestar ou vender tais cópias somente para propósitos acadêmicos e científicos. A autora reserva outros direitos de publicação. Nenhuma parte dessa dissertação de mestrado pode ser reproduzida sem autorização por escrito da autora.

Mayara Pardi de Oliveira

SCLRN $709 \mathrm{Bl} \mathrm{F} \mathrm{apt}{ }^{\circ} 202$

70.750-516 Brasília - DF - Brasil. 
“A utopia está lá no horizonte. Me aproximo dois passos, ela se afasta dois passos. Caminho dez passos e o horizonte corre dez passos. Por mais que eu caminhe, jamais alcançarei. Para que serve a utopia? Serve para isso: para que eu não deixe de caminhar."

(Fernando Birri)

"Ninguém pode persuadir outra pessoa a se modificar. Cada um de nós toma conta da porta da mudança que só pode ser aberta pelo lado de dentro."

(Marilyn Ferguson)

“A educação é o ponto em que decidimos se amamos $o$ mundo $o$ bastante para assumirmos a responsabilidade por ele.”

(Hannah Arendt) 


\section{AGRADECIMENTOS}

Em primeiro lugar agradeço a Deus, por estar sempre ao meu lado me inspirando positivamente e reconfortando nos momentos de angústia, mostrando o caminho certo a seguir e qual o meu papel no mundo, que é junto a natureza, trabalhando e lutando por ela.

A minha maior gratidão às equipes de educação ambiental do Jardim Botânico de Brasília, da Estação Ecológica de Águas Emendadas e do Parque Nacional de Brasília, bem como aos seus gestores por abrirem as portas destas unidades de conservação para esta pesquisa e me receberem de uma forma tão proativa, permitindo que eu me integrasse às atividades e experimentasse vivências lindas de formas variadas com as quais pretendo dar continuidade e preencher a minha vida.

Agradeço a minha família por ajudar a me tornar o que eu sou e que, mesmo longe, sempre foi parte fundamental da minha vida e aos amigos por acreditarem nas minhas escolhas, se fazerem presente nos momentos importantes e também contribuírem no meu processo de aperfeiçoamento pessoal.

Como não agradecer a minha orientadora, Rosana de Carvalho Cristo Martins, por aceitar de pronto minhas ideias e me receber a cada encontro sorridente e disposta a ajudar, com a certeza de que tudo daria certo.

Também não poderia deixar de falar do Departamento de Engenharia Florestal, com todos professores e funcionários, sem os quais não teria a minha graduação e mestrado e que, com todos os ensinamentos e discordâncias, fizeram de mim uma profissional e hoje mestre.

Por fim um agradecimento especial à minha amiga $\mathrm{Ju}$, que me acompanha desde a graduação, sempre me apoiando e acreditando em mim e sem a qual não conseguiria passar por mais essa fase e ter mais essa conquista. 


\title{
ANÁLISE DOS MÉTODOS DE SENSIBILIZAÇÃO DOS PROGRAMAS DE EDUCAÇÃO AMBIENTAL DE TRÊS UNIDADES DE CONSERVAÇÃO DO DISTRITO FEDERAL
}

\author{
Autora: Mayara Pardi de Oliveira \\ Orientadora: Rosana de Carvalho Cristo Martins \\ Programa de Pós-graduação em Ciências Florestais \\ Brasília, Fevereiro, 2016
}

\section{RESUMO}

A presente pesquisa foi realizada em três unidades de conservação do Distrito Federal: Estação Ecológica de Águas Emendadas, Parque Nacional de Brasília e Jardim Botânico de Brasília. A metodologia consistiu em acompanhar e descrever os programas de educação ambiental destas três unidades, além da aplicação de três tipos diferentes de questionário estruturado de acordo com o público-alvo: alunos, professores e equipe de trabalho. A finalidade dos questionários foi identificar qual a visão que se tem à cerca da educação ambiental, como acontece a relação com o meio ambiente, quais as dificuldades enfrentadas, as expectativas, quão conscientes estão quanto a utilização de recursos naturais e conhecimentos sobre o Cerrado. Foi evidenciada a importância do preparo dos professores para a orientação dos alunos no caso do trabalho com crianças, a capacitação das equipes de educação ambiental de todas as unidades de conservação, o conhecimento superficial das crianças e a postura passiva em relação à questão ambiental, demonstrado por meio de gráficos e descrição do que foi acompanhado.

Palavras-chave: Área protegida, questionário estruturado, diferentes públicos-alvo. 


\title{
ANALYSIS OF THE METHODOLOGY OF SENSIBILIZE OF ENVIRONMENTAL PROGRAMS OF THREE PROTECTED AREAS IN FEDERAL DISTRICT
}

\author{
Author: Mayara Pardi de Oliveira \\ Supervisor: Rosana de Carvalho Cristo Martins \\ Programa de Pós-graduação em Ciências Florestais \\ Brasília, February of 2016
}

\begin{abstract}
This research was made in three protected área of the Federal District: Ecological Station of Águas Emendadas, National Park of Brasília and Botanic Garden of Brasília. The methodology consisted of to follow and describe the environmental education program of the three areas plus the application of three differents types of questionnaire: students, teachers and workers. The purpose of the questionnaire as to identify how the environmental education is seen, how is the interaction with it, the issues, expectations, how aware they are about the use of natural resources and knowledge about Cerrado. It is clear how important is to prepare teachers to guide the students, how capacitated are the workers of the three protected areas, the shallow knowledge of the children and the passive posture about environment shown by shown by graphs and the description of what was followed.
\end{abstract}

Keywords: Protected area, structured questionnaires, different audience. 


\section{ÍNDICE DE FIGURAS}

Capítulo I: Análise dos métodos de sensibilização dos programas de educação ambiental aplicados no Parque Nacional de Brasília

Figura Erro! Nenhum texto com o estilo especificado foi encontrado no documento.1: Mapa dos limites do Parque Nacional de Brasília 25

Figura 2: Aula expositiva com Instrutor da Polícia Ambiental

Figura 3: Vista do Lixão da estrutural observada pelos apenados 34

Capítulo II: Análise dos métodos de sensibilização dos programas de educação ambiental aplicados no Estação Ecológica de Águas Emendadas

Figura 1: Mapa dos polígonos da ESECAE 43

Figura 2: Abertura do Curso Reeditor Ambiental no Centro de Informação da ESECAE 47

Figura 3: Prática de automassagem do Curso Reeditor Ambiental na ESECAE 50

Figura 4: Trilha da Lagoa Bonita realizada com os alunos participantes do curso Reeditor Ambiental na ESECAE 51

Figura 5: Percentual de respostas a primeira questão do questionário: " Para você o ESECAE é"

Figura 6: Percentual de respostas à segunda questão do questionário: "A ESECAE existe porque"

Figura 7: Percentual de respostas à terceira questão do questionário: "você visita a ESECAE para"

Figura 8: Percentual de respostas à quarta questão do questionário: "quais animais podem ser vistos no Cerrado"

Figura 9: Percentual de respostas à quinta questão do questionário: "são frutos do Cerrado" 58

Figura 10: Percentual de respostas à sexta questão do questionário: "como proteger a natureza"

Figura 11: Percentual de respostas à sétima questão do questionário: "porque é importante conservar a floresta" 60

Figura 12: Percentual de respostas à oitava questão do questionário: "educação ambiental é" 
Figura 13: Percentual de respostas à nona questão do questionário: "são recursos da natureza que usamos"

Figura 14: Percentual de respostas à décima questão do questionário: "já conhecia a ESECAE" 63

Figura 15: Percentual de respostas à décima primeira questão do questionário: "já visitou outra UC/parque" 64

Figura 16: Resposta à questão: "Quais as dificuldades encontradas para aplicação da EA na sua escola?"

Figura 17: Resposta à questão: "Qual a sua expectativa em relação ao curso?" 66

Figura 18: Resposta à questão: "Como pretende desenvolver a EA no espaço da ESECAE?"

\section{Capítulo III: Análise dos métodos de sensibilização dos programas de educação ambiental aplicados no Jardim Botânico de Brasília}

Figura 1: Mapa da localização do Jardim Botânico de Brasília no Distrito Federal ..... 74

Figura 2: Automassagem no ninho do pássaro do Jardim Botânico de Brasília ........... 77

Figura 3: Apresentação de vídeo informativo no Jardim Botânico de Brasília ............. 77

Figura 4: Caminhada pela área do Jardim Botânico de Brasília ................................... 78

Figura 5: Percentual de respostas à primeira questão do questionário: "Para você o JBB é"

Figura 6: Percentual de respostas à segunda questão do questionário: "O JBB existe

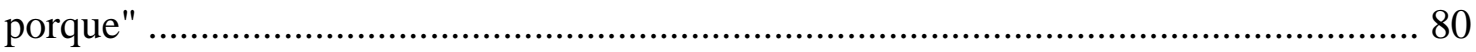

Figura 7: Percentual de respostas à terceira questão do questionário: "Visita o JBB para"

Figura 8: Percentual de respostas à quarta questão do questionário: "Quais animais podem ser vistos no Cerrado?"

Figura 9: Percentual de respostas à quinta questão do questionário: "São frutos do Cerrado"

Figura 10: Percentual de respostas à sexta questão do questionário: "Como proteger a natureza?"

Figura 11: Percentual de respostas à sétima questão do questionário: "Por que é importante conservar as florestas?" 
Figura 12: Percentual de respostas à oitava questão do questionário: "Educação

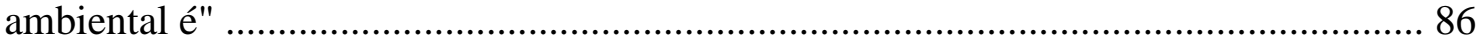

Figura 13: Percentual de respostas à nona questão do questionário: "São recursos da natureza que usamos" 87

Figura 14: Percentual de respostas à décima questão do questionário: "Já conhecia o JBB?" 88

Figura 15: Percentual de respostas à décima primeira questão do questionário: "Já visitou outra UC/parque?" 


\section{ÍNDICE GERAL}

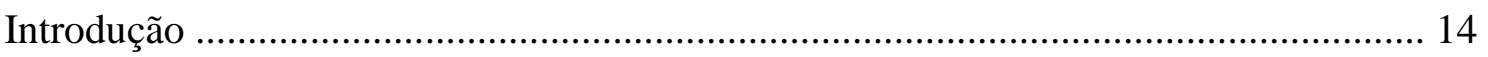

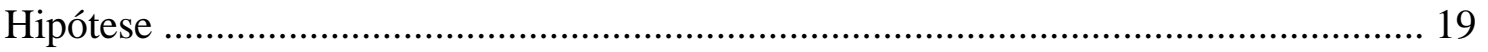

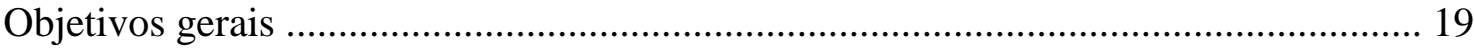

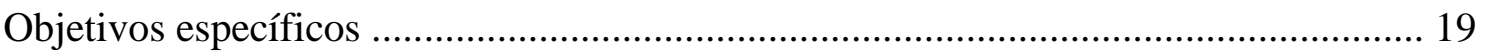

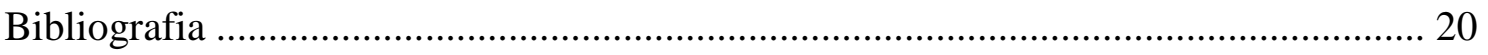

Capítulo I: Análise dos métodos de sensibilização dos programas de educação ambiental aplicados no Parque Nacional de Brasília............................................. 22

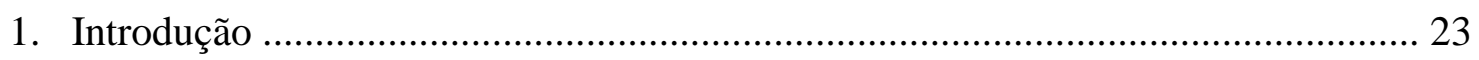

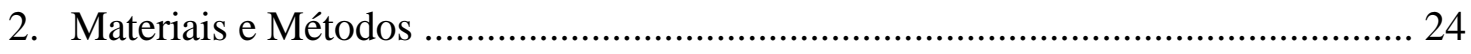

2.1.Caracterização da área de estudo ................................................................... 24

2.2.Caracterização do programa de educação ambiental ........................................ 25

2.2.1. Acompanhamento das atividades ........................................................ 25

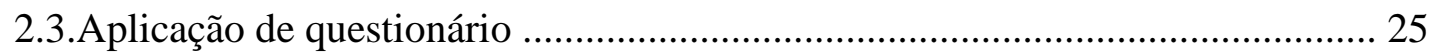

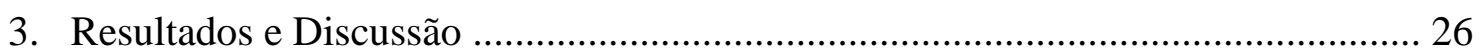

3.1.Caracterização do Programa de Educação Ambiental do PNB.......................... 26

3.2.Programa de Educação Ambiental do PNB ..................................................... 26

3.2.1. Curso de Educação Ambiental aos Educadores/Reeditores ..................... 26

3.2.2.Curso de Formação Socioambiental para Ilícitos Ambientais e Urbanísticos 27

3.2.3.Projeto Leitura e Percepção Ambiental Pelas Trilhas do Parque ............. 28

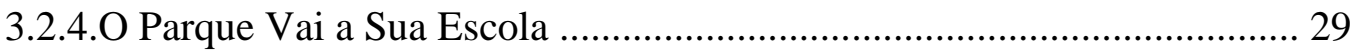

3.2.5.Educação Ambiental Como Instrumento de Prevenção aos Incêndios Florestais e Técnicas Alternativas ao Uso do Fogo para o entorno da UC ....... 29

3.2.6.Educação Ambiental aos Usuários do Parque ........................................... 30

3.2.7.Atendimento às escolas e visitantes ao CEA ............................................ 30

3.2.8.Projeto Pesquisa-ação e Elaboração de Materiais Educativos .................. 30

3.2.9. Revitalização do Centro de Educação Ambiental (CEA) do NEA/PNB

3.2.10.Projeto voluntário/estagiários ......................................................... 32 
3.2.11.Projeto de Identificação de Espécies Arbóreas Nativas na Área de Visitação 32

3.3. Dados extraídos a partir do questionário estruturado aplicado à equipe de

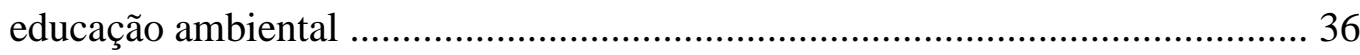

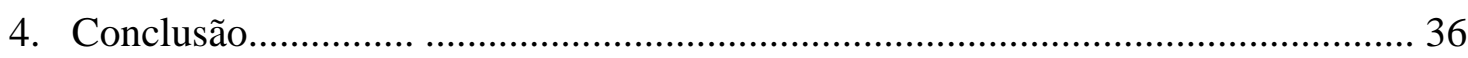

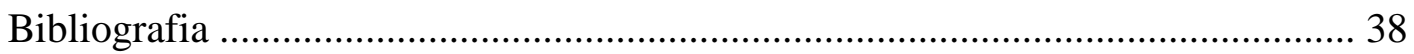

Capítulo II: Análise dos métodos de sensibilização dos programas de educação ambiental aplicados na Estação Ecológica de Águas Emendadas 40

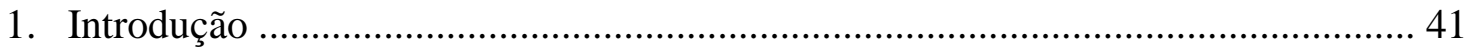

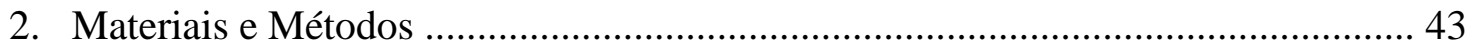

2.1. Caracterização da área de estudo .................................................................. 43

2.2. Caracterização do programa de educação ambiental da ESECAE ................. 44

2.2.1. Aplicação de questionário ................................................................ 44

2.2.1.1. Participantes ............................................................. 44

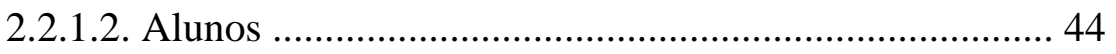

2.2.1.3. Equipe de educação ambiental ................................... 45

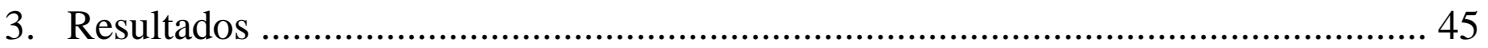

3.1. Nossa Escola Pesquisa Sua Opinião - NEPSO ............................................ 45

3.2. Programa Reeditor Ambiental ..................................................................... 46

3.2.1. Dança Circular ............................................................................ 49

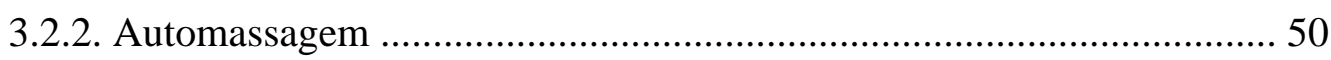

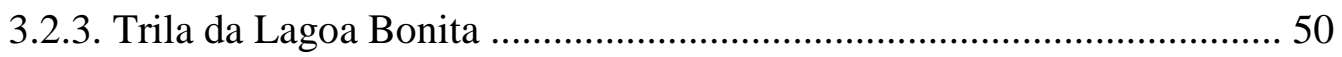

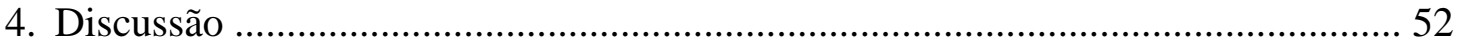

4.1. Descrição do programa Reeditor Ambiental ............................................... 52

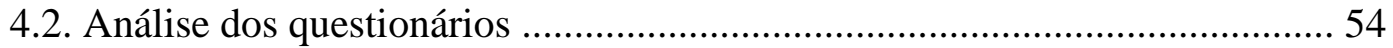

4.2.1. Questionários aplicados aos Alunos ................................................... 54

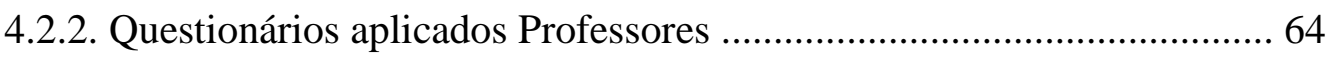

4.2.3. Dados extraídos a partir do questionário estruturado aplicado à equipe de

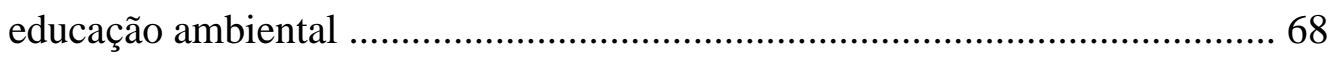

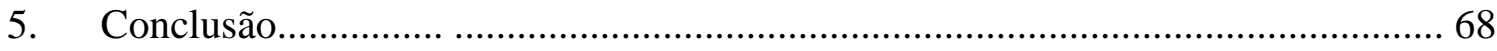

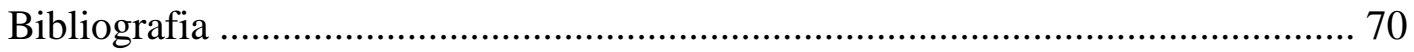


Capítulo III: Análise dos métodos de sensibilização dos programas de educação ambiental aplicados no Jardim Botânico de Brasília 72

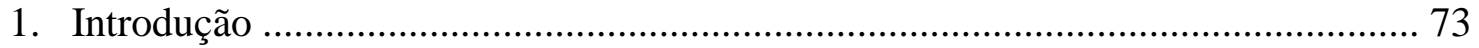

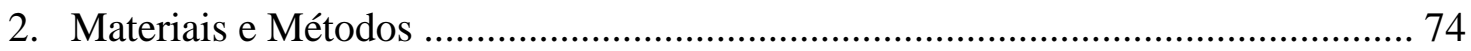

2.1. Caracterização da área de estudo ............................................................ 74

2.2. Caracterização do programa de educação ambiental do JBB ....................... 75

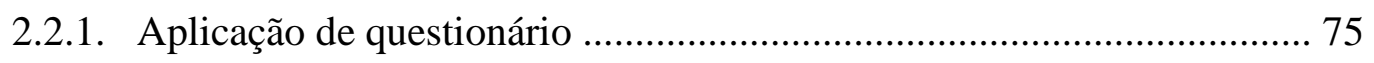

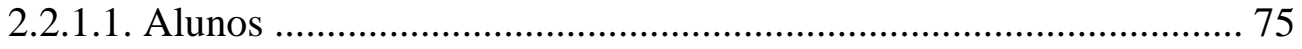

2.2.1.2. Equipe de educação ambiental ...................................................... 76

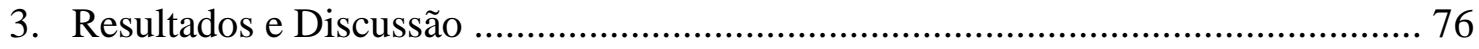

3.1. Descrição do programa de educação ambiental ........................................... 76

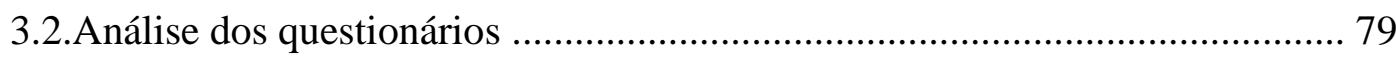

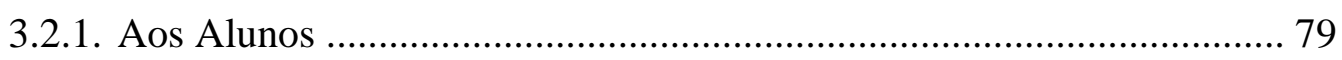

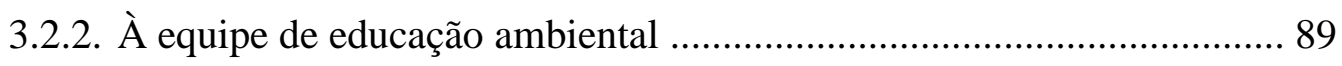

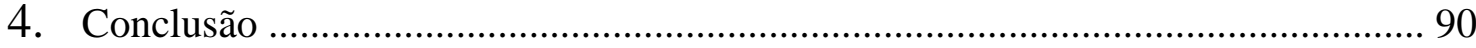

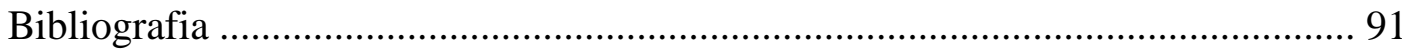

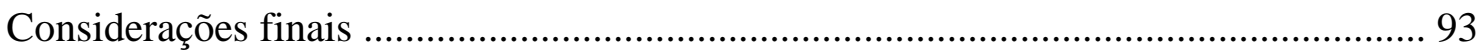

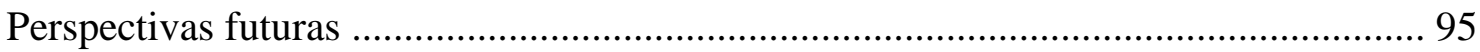

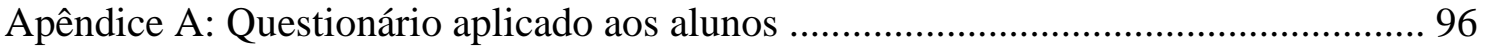

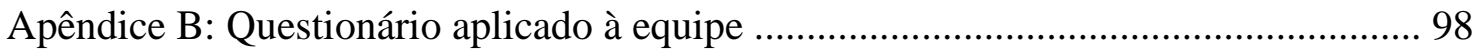

Apêndice C: Questionário aplicado aos professores .................................................. 99 


\section{INTRODUÇÃO}

Ainda que o termo educação ambiental (EA) tenha sido mencionado pela primeira vez, segundo a literatura, na década de 1960, apenas no ano de 1975 que ela foi reconhecida como estratégia de formação de sociedades sustentáveis pelo Programa Internacional de Educação Ambiental (PIEA). Este Progeama, que surgiu como parte dos primeiros resultados à Recomendação 96 da Conferência de Estocolmo, ocorrida em 1972 e responsável pela inserção da EA na agenda mundial (ProNEA, 2003).

A consolidação do PIEA veio dois anos mais tarde, em 1977, com a Conferência Intergovernamental sobre Educação Ambiental, mais conhecida como Conferência de Tbilisi que estabeleceu as finalidades, objetivos, princípios orientadores e as estratégias de promoção da educação ambiental. (ProNEA, 2003).

Em relação ao Brasil, a EA surge de forma informal e difusa, manifestando-se por meio de artigos, movimento conservacionista e até mesmo uma legislação conservacionista no século XIX, início do século XX. A sua institucionalização veio, oportunamente, com a criação, no Poder Executivo, da Secretaria Especial do Meio Ambiente (SEMA), em 1973, atrelada ao Ministério do Interior (ProNEA, 2003). Apesar de estar ligada a um ministério desenvolvimentista, a SEMA definiu como sua responsabilidade "o esclarecimento e a educação do povo brasileiro para o uso adequado dos recursos naturais, tendo em vista a conservação do meio ambiente" (ProNEA, 2003).

No Poder Legislativo foi criada no ano de 1981, a Política Nacional de Meio Ambiente (PNMA), Lei n ${ }^{\circ}$ 6.938/81, objetivando além da preservação e recuperação da qualidade ambiental, garantir o necessário ao desenvolvimento socioeconômico. Ela aponta como necessária a inclusão da educação ambiental em todos os níveis de ensino, ensejando a capilaridade desta prática educativa. Também foi a responsável por constituir o Sistema Nacional do Meio Ambiente (SISNAMA) e o Cadastro de Defesa Ambiental (BRASIL, 1981).

Estes objetivos foram fortalecido pela Constituição Federal de 1988, que estabeleceu em seu artigo 225, inciso VI, a necessidade de "promover a educação ambiental em todos os níveis de ensino e a conscientização pública para a preservação do meio ambiente". Os recursos para esta finalidade passaram a ser repassados pelo Fundo Nacional do Meio Ambiente (FNMA) a partir de 1989, com a criação da Lei $n^{\circ}$ 7.797 (ProNEA, 2003). 
Outro marco foi a realização da Conferência Rio-92, onde a sua comissão organizadora considerou a EA como sendo um dos instrumentos da política brasileira. No Fórum, foi estabelecido o Tratado de Educação Ambiental para Sociedades Sustentáveis e Responsabilidade Global, se tornando um marco mundial. Ainda no mesmo evento foi escrita a Carta Brasileira para Educação Ambiental, que reconhece esta como sendo um instrumento fundamental para viabilizar a sobrevivência do planeta (ProNEA, 2003).

Ainda neste ano foi criado o Ministério do Meio Ambiente (MMA) e instituídos os Núcleos de EA em todas as superintendências regionais do IBAMA (ProNEA, 2003).

Outros eventos significativos ao tema foram: a execução do Programa Nacional de Educação Ambiental (PRONEA) em 1994, os Parâmetros Curriculares Nacionais em 1997 e finalmente a instituição da Política Nacional de Educação Ambiental (PNEA), Lei n⿳⺈ 9.795/99. Importante ressaltar que neste ano de 1999 foi lançado um outro Programa de Educação Ambiental cuja sigla é ProNEA (ProNEA, 2003).

A PNEA foi regulamentada pelo Decreto $n^{\circ} 4.281 / 02$ e entende a educação ambiental como sendo "os processos por meio dos quais o indivíduo e a coletividade constroem valores sociais, conhecimentos, habilidades, atitudes e competências voltadas para a conservação do meio ambiente, bem de uso comum do povo, essencial à sadia qualidade de vida e sua sustentabilidade”, reforça que deve estar presente em todos os níveis de ensino de maneira formal e não-formal e o mais importante, transforma a EA em um direito de todos os cidadãos (portal.mec.gov, 2015).

Por ensino não-formal pode-se entender um ensino que não é praticado em sala de aula, no entanto é necessário um ambiente adequado e profissionais preparados para sua prática. Pode ocorrer, por exemplo, em unidades de conservação (UC) que constam entre seus objetivos, segundo o Sistema Nacional das Unidades de Conservação da Natureza (SNUC) em seu artigo $4^{\circ}$ inciso XII "favorecer condições e promover a educação e interpretação ambiental, a recreação em contato com a natureza e o turismo ecológico" (SNUC, 2003).

Desta forma, além do atendimento à sociedade em geral, é de fundamental importância a integração com os agentes atuantes nas unidades ou nos entornos. A EA é uma ferramenta que auxilia no compartilhamento de informações qualificadas e atuais de forma participativa, expandindo a janela de diálogo e favorecendo uma ação conjunta, compromissada com a missão da unidade de conservação (IBASE, 2006). 
Ainda segundo o Ibase (2006), é preciso relacionar as práticas educacionais em UC ao desenvolvimento social de um modo geral, particularmente a acalorada discussão entre proteção da biodiversidade e a integração com comunidades do entorno. É preciso considerar também o contexto mundial de disputa pelos recursos de forma desigual resultando em um quadro de pobreza e degradação ambiental.

Segundo Loureiro e Cunha (2008) unidades de conservação são, por definição, áreas de conflitos, por isso é essencial haver um espaço democrático para participação e controle social, apontando a educação ambiental crítica e emancipatória como um caminho possível na gestão de áreas protegidas (LOUREIRO e CUNHA, 2008).

Sendo a EA muito diversa, é interessante ter como ponto de partida qual a ideia que educadores e educandos possuem sobre educação e meio ambiente, para então entender seu processo. No entanto, as dificuldades de cada nação não hão de ser solucionados apenas por meio da educação, apesar de não poderem ser resolvidos sem ela (IBASE, 2006).

Sendo assim pode-se enxergar a educação ambiental como sendo uma prática socioeducativa integrada, contínua e permanente cujo objetivo é informar, sensibilizar e comprometer a sociedade e gestores quanto a realidade ambiental, de forma que, em conjunto com a gestão ambiental se transformam em instrumentos fundamentais na manutenção do equilíbrio entre ambiente e sociedade (ALCÂNTARA, 2012). Para este autor:

[...] a Educação Ambiental deve ser vista, acima de tudo, como uma mudança de atitudes e, ser colocada como um ato político voltado para a transformação social, considerando a necessidade da sustentabilidade ecológica, social e econômica, buscada através de intervenções integradoras e coordenadas (ALCÂNTARA, 2012).

O autor Zitzke (2002) aponta a importância da educação ambiental afirmando que esta viabiliza o entendimento entre a relação humana com todo o ambiente, fomentando uma ética ambiental que desperta um anseio de construção da cidadania (ZITZKE, 2002).

Um grande estudioso do tema, Mauro Guimarães, aponta para as diversidades de práticas pedagógicas relacionas a EA, mas ressalta principalmente o papel sociopolítico de suas duas vertentes principais: crítica e conservadora. Ele defende que a transformação da sociedade decorre da transformação de cada indivíduo e afirma que, apesar de já se encontrar estabelecida nas escolas em geral, a educação ambiental 
praticada se apresenta fragilizada e contraditória entre discurso e prática, "realizando atividades pontuais descontextualizadas da realidade socioambiental" (GUIMARÃES, 2004).

Essencialmente político, o conceito de educação ambiental vem sendo modificado com o tempo, afastando-se da visão naturalista que enfoca os processos físicos e biológicos ambientais e se aproximando de uma visão socioambiental, enfocando a relação entre a vida humana e a biológica (CARVALHO, 2006).

Segundo Jacobi (2003) a postura de dependência e falta de responsabilidade ambiental da população decorre principalmente da desinformação, da falta de consciência ambiental e de um déficit de práticas comunitárias baseadas na participação e no envolvimento dos cidadãos, que proponham uma nova cultura de direitos com base na motivação e na participação da gestão ambiental. O chamado desenvolvimento sustentável acontece nesse processo de corresponsabilidade individual, objetivo principal da educação ambiental (JACOBI, 2003).

No entanto, Sauvè (2005) define a predominância da ideologia do desenvolvimento como sendo o maior entrave atual, reduzindo a educação a instrumento de conservação a um longo prazo, encarando o ambiente como reservatório de recursos que garantirá o crescimento. Essa interpretação demonstra que o tripé do desenvolvimento sustentável funciona de forma que a economia determina a relação humana com o meio ambiente (SAUVÈ, 2005).

O Ministério do Meio Ambiente (MMA) afirma estar havendo uma mudança, tanto individual quanto coletiva, "nos modos de ser, viver, produzir e consumir" e que esta deve ser fortalecida, tornando estratégica a Política Nacional de Educação Ambiental (MMA, 2003). Para garantir as condições necessárias à gestão desta política foi criado o Programa Nacional de Educação Ambiental (ProNEA), encarregado de articular ações educativas voltadas à proteção, assim como "potencializar a função da educação para as mudanças culturais e sociais" (ProNEA, 2005).

O MMA atribui à educação ambiental a tarefa de construir o que foi chamado de "utopia possível", com padrões de consumo e produção adequados, recuperação da degradação com causa antrópica, sem miséria, sinergia de saberes acadêmicos e tradicionais dentre outros (MMA, 2009).

Para tanto são necessário trabalhos de EA, cujo sucesso é medido pela transformação na rotina diária de seus envolvidos, com consequente diminuição dos 
impactos ambientais devido à alteração dos hábitos de vida das pessoas que participam direta ou indiretamente desse projeto (VEIGA \& COSSÍO 2005).

"A educação ambiental acompanha e sustenta de início o surgimento e a concretização de um projeto de melhora da relação de cada um com o mundo, cujo significado ela ajuda a construir, em função das características de cada contexto em que intervém" (SAUVÉ, 2005).

Considerado superado o momento de questionamento e fundamentação quanto à relevância da questão ambiental seja para a sociedade, para o cotidiano dos cidadãos, para o planejamento urbano ou para a academia, é necessário buscar um amadurecimento das questões teórico-metodológicas das pesquisas relacionadas a EA, promovendo uma reflexão qualificada (PEDRINI e SAITO, 2014).

Ruscheinsky e Bortolozzi, em uma obra publicada por vários autores, recomendam que o pesquisador parta de uma ação, uma prática de cidadania, para refletir sobre o que vê ao invés de uma teorização prévia que pode não corresponder à realidade, para então retornar com sugestões (RUSCHEINSKY e BORTOLOZZI in: PEDRINI e SAITO, 2014).

Em concordância com esta ideia, a proposta deste trabalho é partir das respostas dadas aos questionários aplicados para se conhecer a visão dos usuários das unidades de conservação investigadas (Jardim Botânico de Brasília, da Estação Ecológica de Águas Emendadas e do Parque Nacional de Brasília), da formação dos profissionais atuantes e do tipo de trabalho desenvolvido; podendo, por fim, descrever o processo de transferência de conhecimento, dando as contribuições possíveis, de acordo com os limites desta pesquisa. 


\section{HIPÓTESE}

As unidades de conservação do Jardim Botânico de Brasília, da Estação Ecológica de Águas Emendadas e do Parque Nacional de Brasília sistematizam a educação ambiental como instrumento de gestão para atender aos seus objetivos de conservação.

\section{OBJETIVOS}

\section{OBJETIVO GERAL}

Avaliar a sistemática adotada por três unidades de conservação do Distrito Federal (Estação Ecológica Águas Emendadas (ESECAM), Parque Nacional de Brasília (PNB) e Jardim Botânico de Brasília (JBB)) na transferência do conhecimento e na sensibilização ambiental junto aos visitantes e usuários das mesmas.

\section{OBJETIVOS ESPECÍFICOS}

$\checkmark$ Descrever o processo de sensibilização ambiental para o público infantil do Jardim Botânico de Brasília (JBB), do Curso de Formação Socioambiental do Parque Nacional (PN) e do Programa Reeditor Ambiental da Estação Ecológica de Águas Emendadas (ESECAE).

$\checkmark$ Identificar qual a percepção dos usuários destas unidades em relação ao Cerrado, a sua conservação e quanto a importância da aplicação da educação ambiental.

$\checkmark$ Verificar como a educação ambiental é utilizada como ferramenta de gestão nas unidades de conservação.

$\checkmark$ Contribuir com o enriquecimento dos programas estudados fornecendo os dados obtidos como subsídio. 


\section{BIBLIOGRAFIA}

ALCÂNTARA et al., v(5), nº 5, p. 734 - 740, 2012. Revista Eletrônica em Gestão, Educação e Tecnologia Ambiental REGET/UFSM (e-ISSN: 2236-1170).

BRASIL, Ministério do Meio Ambiente e Ministério da Educação. Programa Nacional de Educação Ambiental. Brasília, DF: MMA e MEC, $3^{\circ}$ Edição. 2005. 112p.

BRASIL, Ministério do Meio Ambiente. Os Diferentes Matizes da Educação Ambiental no Brasil: 1997-2007. Série Desafios da Educação Ambiental. Brasília, DF: MMA, 2009. 290p.

BRASIL. Lei $n^{0}$ 6.938/81. Política Nacional do Meio Ambiente. Diário Oficial [República Federativa do Brasil], Brasília, DF, 02 set 1981. Seção I, Página 16509.

BRASIL. Lei $\mathrm{n}^{0}$ 9.394, de 20 de dezembro de 1996. Estabelece as diretrizes e bases da educação nacional. Diário Oficial [da República Federativa do Brasil], Brasília, DF, v. 134, n. 248, 23 dez. 1996. Seção I, p. 27834-27841.

BRASIL. Lei no 9.795, de 27 de abril de 1999. Dispõe sobre a educação ambiental, institui a Política Nacional de Educação Ambiental e dá outras providências. Diário Oficial [da República Federativa do Brasil], Brasília, DF, n. 79, 28 abril 1999, (Publicação Original). Seção I.

CARVALHO, Isabel de Moura. A formação do sujeito ecológico. 2 ed. São Paulo: Cortez, 2006.

Educação Ambiental em Unidade de Conservação. Instituto Brasileiro de Análises Sociais e Econômicas (Ibase). Rio de Janeiro: Ibase, 2006.

GUIMARÃES, Mauro. A formação de educadores ambientais. Campinas, SP: Papirus, 2004. - (Coleção Papirus Educação)

JACOBI, P. Educação ambiental, cidadania e sustentabilidade. Cadernos de Pesquisa, n. 118, p. 189-205, março, 2003.

LOUREIRO, C. F. B. CUNHA, C. C. Educação ambiental e gestão participativa de unidades de conservação: elementos para se pensar a sustentabilidade democrática. Ambiente \& Sociedade. v. XI, n. 2 p. 237-253. Campinas: jul-dez/ 2008.

Padua S.M. e TABANEZ M.F. (orgs.). Educação Ambiental: Caminhos Trilhados no Brasil. Brasília: IPE - Instituto de Pesquisas Ecológicas, 1997. p. 119-131.

PEDRINI. A. G. SAITO, C.H. (Org.). Paradigmas metodológicos em educação ambiental. Petrópolis, RJ: Vozes, 2014.

Plano de Manejo do Parque Nacional de Brasília. Convênio IBAMA - FUNATURA. Sem data.

Programa nacional de educação ambiental - ProNEA/Ministério do Meio Ambiente, Diretoria de Educação Ambiental; Ministério da Educação. Coordenação Geral de 
Educação Ambiental. - $3^{\circ}$ ed - Brasília: Ministério do Meio Ambiente, 2005. 102 p.: il. $21 \mathrm{~cm}$.

SAUVÉ, Lucie. Educação ambiental: possibilidades e limitações. Educação e Pesquisa, São Paulo, v. 31, n. 2, p. 317-322, maio/ago. 2005

Sistema Nacional de Unidades de Conservação da Natureza - SNUC: Lei ํㅜ 9.985, de 18 de julho de 2000; decreto n⿳⺈-4.340, de 22 de agosto de 2002. 3 ed. Aum. Brasília: MMA/SBF, 2003. 52p.

VEIGA, Alinne; AMORIM, Érica Pereira; BLANCO COSSÍO, Mauricio. Um retrato da presença da educação ambiental no ensino fundamental brasileiro: o percurso de um processo acelerado de expansão. Brasília: INEP, 2005.

ZITZKE, V. A. Educação Ambiental e Ecodesenvolvimento. Revista Eletrônica do Mestrado em Educação Ambiental. v. 9, 2002. Disponível em: $<$ http://www.fisica.furg.br/mea/remea/vol9/a13art16.pdf $>$. Acesso em: 22 jul de 2011.

ICMBio. Unidades de Conservação. Parque Nacional de Brasília. Disponível em: <http://www.icmbio.gov.br/portal/biodiversidade/unidades-de-conservacao/biomasbrasileiros/cerrado/unidades-de-conservacao-cerrado/2095-parna-de-brasilia.html>. Acesso em: 28 maio de 2015. 


\title{
CAPÍTULO I: ANÁLISE DOS MÉTODOS DE SENSIBILIZAÇÃO DOS PROGRAMAS DE EDUCAÇÃO AMBIENTAL APLICADOS NO PARQUE NACIONAL DE BRASÍLIA
}

\section{Resumo}

O Parque Nacional de Brasília conta com o Núcleo de Educação Ambiental, que tem por missão desenvolver as ações do programa de educação ambiental. A gestão atual do Parque tem firmado um convênio com o Ministério Público e recebe grupos de apenados por ilícitos ambientais para serem sensibilizados ambientalmente e esclarecidos quanto à legislação pertinente, como parte das medidas socioeducativas determinadas em juízo. O objetivo deste capítulo foi verificar as metodologias e abordagens aplicadas a este grupo para promoção da educação ambiental. Foram acompanhadas as técnicas aplicadas pelos instrutores: trilha interpretativa no parque, aula expositiva e visita técnica ao Lixão da Estrutural. As metodologias despertaram nos educandos a percepção de pertencimento ao meio ambiente e, somada as aulas de legislação, foi possível identificar uma mudança de postura em relação ao meio ambiente, a utilização dos recursos e a produção de lixo, tendo sempre em mente as experiências do curso.

Palavras-chave: Crime ambiental, meio ambiente, lei.

\begin{abstract}
The Brasília National Parque has an Environmental Education Center which has the mission to develop the environmental education program. The current management of the Park has an agreement with the Prosecution Service to receive groups of environment transgressor to attend an environmental sensibilization and the relevant legislation as educational measures. The aim of this study was to evaluate the methodologies and approaches applied to this group to promote environmental education. The methodologies used by the instructors were followed: interpretive trail in the Park, lecture and technical visit to the Estrutural Dump. The methodologies aroused in participants a sense of belonging to the environment and along with the law classes was possible to identify a change of attitude toward the environment, resource use and waste production, having in mind the course experiences.
\end{abstract}

Keywords: Environmental crime, environment, law. 


\section{INTRODUÇÃO}

$\mathrm{O}$ crescimento populacional implica no atendimento às necessidades dessa população, o que significa aumento na produção alimentar, infraestrutura, produção de energia, baseados em um sistema político e econômico de acúmulo de riquezas e consumismo exagerado, explorando desenfreadamente os recursos naturais. Então o que o homem precisa é ser educado para respeitar o ambiente (MARCONDES e SOARES, 1991).

Este aumento generalizado implica no aumento da produção de lixo, cujo descarte costuma ser sempre problemático, optando-se, na maioria das vezes, por depósitos a céu aberto, formando os lixões, que devem ser afastados de áreas residenciais, agrícolas e reservatórios hídricos (MARCONDES e SOARES, 1991).

A problemática ambiental surge a partir da crise no processo de modernização, orientado pelo raciocínio econômico, com uma visão utilitarista dos recursos naturais (LEFF, 2001).

Visando a conservação destes recursos foram criadas áreas chamadas unidades de conservação (UC), organizadas no Sistema Nacional de Unidades de Conservação (SNUC), sendo classificadas em doze categorias de proteção integral e de uso sustentável (SNUC, 2006). A categoria Parque Nacional (proteção integral) é de domínio público, podendo ser criado na estância federal, estadual e municipal, sendo regido pelo seu plano de manejo que estabelece as normas de visitação pública, pesquisas científicas, atividades de educação e interpretação ambiental entre outras visando a preservação de ecossistemas naturais relevantes e de beleza cênica (SNUC, 2006).

Segundo o IBAMA-PAE/Horowitz (1995), citados por IBAMA e FUNATURA s/d, as piscinas da Água Mineral recebem mais de oitocentas mil pessoas por ano que desconhecem tudo sobre o resto do Parque. Como solução a este problema conta-se com um programa de educação ambiental (EA) voltado principalmente para a visitação de escolas, sendo executado pelo centro de visitantes (CV) (IBAMA e FUNATURA, s/d).

Toledo (2002) se propôs a debater as atividades de EA desenvolvidas em unidades de conservação (UCs). Essa autora investigou os subprogramas de EA de Parques Estaduais do Estado de São Paulo, segundo a qual justificava-se pelo aumento do número de visitantes, o que indica "crescente interesse da sociedade por questões ligadas ao meio ambiente". A autora constatou existir poucos estudos sobre atividades que permitem um maior contato com a natureza, seja para fins de contemplação, lazer 
ou educação e afirma que estas têm aumentado e se diversificado, inclusive por meio de programas de EA em UCs. No entanto, considerando as preocupações ligadas às garantias de proteção e conservação dessas áreas, é fundamental que o programa de EA seja planejado e implementado em conformidade com esse propósito.

Guimarães (1995) afirma que a educação ambiental tem dado uma contribuição significativa, no entanto de forma lenta e silenciosa e explica Martins (2013) que a efetividade da mesma se encontra na consciência individual de cada um.

Segundo o Ministério do Meio Ambiente a educação ambiental é encarregada do que foi chamada de utopia possível onde os padrões de produção e consumo são adequados, atuando em um cenário hipercomplexo desenvolvendo teorias e práticas para ser crítica, transformadora e emancipatória, preparando as pessoas para uma conduta ativa (MMA, 2009).

Baseado nesta orientação da educação ambiental este trabalho teve por objetivo descrever o programa de educação ambiental do Parque Nacional de Brasília, com um estudo de caso do Curso de Formação Socioambiental para Ilícitos Ambientais e Urbanísticos, com foco principal na aplicação das metodologias utilizadas na tentativa de sensibilização dos ilícitos ambientais e as respostas observadas nos educandos durante o processo. Assim como caracterizar a equipe responsável.

\section{MATERIAIS E MÉTODOS}

\subsection{Caracterização da área de estudo}

O Parque Nacional de Brasília está localizado na região noroeste do Distrito Federal, a aproximadamente $10 \mathrm{~km}$ do centro de Brasília, abrangendo também as regiões administrativas de Sobradinho-DF, Brazlândia e Padre Bernardo, município de Goiás, contando com uma área de 42.389,01 hectares (Figura 1).

Os limites do PNB são:

- Limite Norte: Estrada Parque do Contorno - EPCT (DF-001)

- Limite Nordeste: Estr. Parque do Contorno - EPCT (DF-001)

- Limite Leste: Estr. Parque Indústria e Abastecimento - EPIA (DF-003)

- Limite Oeste: Estrada Parque do Contorno - EPCT (DF-001)

- Limite Sul: Córrego Acampamento

- Limite Sudoeste: (DF-097) 


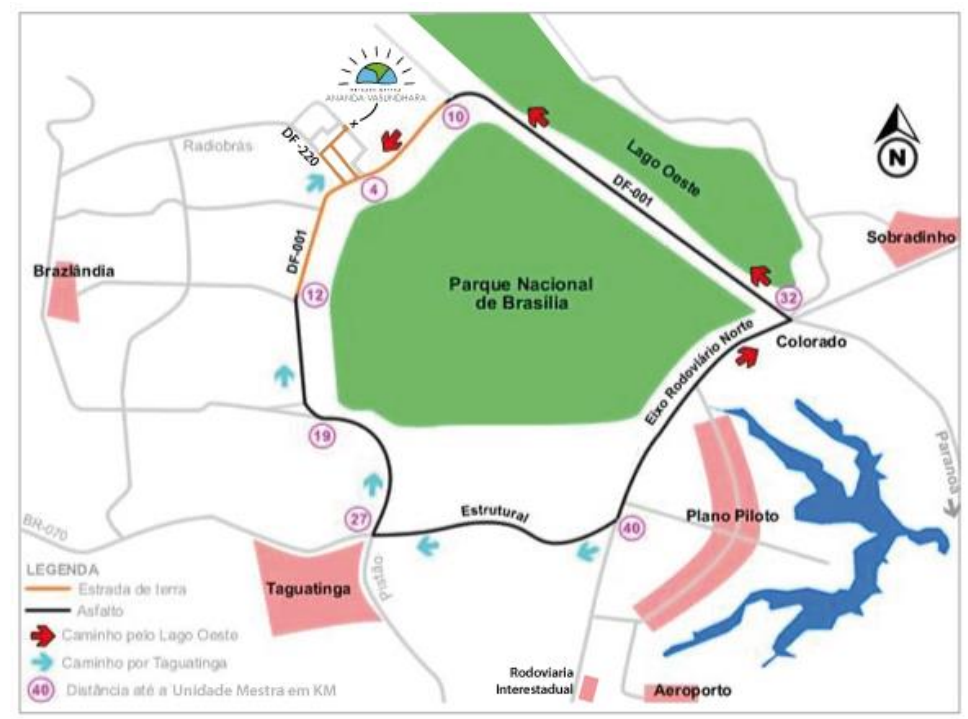

I - Figura 1. Mapa dos limites do Parque Nacional de Brasília. Fonte: ICMBio-MMA.

Dentro de sua área estão protegidas formações de campo úmido, cerrado sensu stricto, campo rupestre, mata de galeria pantanosa e não pantanosa, campo de murunduns, veredas, campo sujo e campo limpo. Além da flora, também se encontram espécies de fauna ameaças de extinção e típicas do Cerrado.

O clima seco é classificado por Köppen no tipo Cwhl, clima temperado e úmido de altitude, com uma variação média de temperatura entre $18^{\circ} \mathrm{C}$ no inverno e $22^{\circ} \mathrm{C}$ no verão (IBAMA e FUNATURA, s/d).

\subsection{Caracterização do programa de educação ambiental}

Baseada na metodologia aplicada por Martins (2013) no Parque Nacional de Brasília, a coleta de dados desta pesquisa consistiu-se em duas etapas: I) acompanhar as atividades desenvolvidas pela equipe de educação ambiental e II) aplicação de questionário.

\subsubsection{Acompanhamento das atividades}

Acompanhar as atividades desenvolvidas pela equipe de educação ambiental do Parque Nacional de Brasília quando no momento do Curso de Formação Socioambiental, não tendo sido acompanhada as atividades administrativas.

\subsection{Aplicação de questionário}

O questionário foi elaborado baseado na metodologia de Martins (2013), com o intuito de caracterizar a equipe de trabalho e conhecer suas dificuldades.

Para identificar o perfil da equipe responsável pelo Programa de EA foram desenvolvidas quatro perguntas subjetivas referentes a formação de cada integrante, o 
tempo de trabalho dentro da unidade de conservação, qual a atuação dentro do Programa e quanto ao treinamento para ministrar as atividades (Apêndice B). Um questionário desta natureza permite a inclusão de outros dados por parte dos respondentes caso desejem.

\section{RESULTADOS E DISCUSSÃO}

\subsection{Caracterização do Programa de Educação Ambiental do PNB}

O Parque Nacional de Brasília (PNB) conta com um dos Núcleos de Educação Ambiental instaurados pelo IBAMA bem antes da sua divisão. É deste núcleo a responsabilidade de promover o programa de educação ambiental do PNB, cuja missão se resume em auxiliar na concepção de uma consciência socioambiental de forma ética. Para tanto é desenvolvido um planejamento anual que funciona no Centro de Educação Ambiental (CEA) da unidade, sendo também o Centro de Visitantes (CV).

A importância deste programa não está apenas no cumprimento do Plano de Manejo do Parque, mas também é uma das ferramentas pela qual se busca a sua sustentabilidade, sensibilizando seus usuários e se compatibilizando com a realidade socioambiental que está inserido.

O PNB conta com onze projetos e ações de educação ambiental, no entanto infelizmente não foi possível acompanhar a todos eles, principalmente pela maioria estar voltada às escolas, portanto estão sujeitos a procura pelas mesmas; em 2015, as greves de professores e servidores prejudicaram a procura por este programa.

O projeto que foi acompanhado para esta pesquisa é intitulado Curso de Formação Socioambiental para Ilícitos Ambientais e Urbanísticos; no entanto, todos os demais são descritos a seguir. Também é apresentado o resultado da aplicação do questionário estruturado aos responsáveis pelo programa.

\subsection{Programa de Educação Ambiental do PNB}

\subsubsection{Curso de Educação Ambiental aos Educadores/Reeditores}

Este projeto é destinado aos educadores, monitores e agentes ambientais das escolas da Secretaria de Educação do DF - SEEDF; COSES da Secretaria de Ação Social do DF - SEDEST e outras entidades.

Funciona como um espaço aberto ao debate e planejamento de atividades voltadas a estudantes objetivando a parceria com os professores para a formação de uma consciência socioambiental. 
A questão fundamental deste curso é ampliar os horizontes dos educadores. Quando se trata de projetos de educação ambiental em escolas o primeiro pensamento é sempre trabalhar com hortas, coleta seletiva e aproveitamento de sucata, o que de fato tem seu valor e gera resultados muito positivos, no entanto os trabalhos são resumidos à essas práticas.

Uma vez entendido que a EA não está circunscrita em uma matéria e sim abrange práticas e conteúdos interdisciplinares, as possibilidades são infinitas, o que é tão positivo quanto negativo quando não se tem objetivos bem definidos e orientação adequada.

Martins (2013) afirma ser grande a diferença entre as vivências pessoais dos professores e as práticas de educação ambiental, enfatizando que a educação formal não pode ser dissociada da vivência ambiental. No mesmo trabalho é relatado que a falta de capacitação na temática ambiental é a mesma falta de incentivo para que ela ocorra.

A referida autora, ao indagar professores na sua pesquisa a respeito do que é uma unidade de conservação, revela que a maioria de 34,96\% afirma ser um local para conservar; no entanto, as outras opções: proteger a natureza $(22,76 \%)$, conservar fauna e flora $(26,02 \%)$ e preservar recursos naturais $(16,26 \%)$, idealizam praticamente a mesma coisa; sendo assim, o que faz com que se escolha uma opção e não a outra? A falta de visão sistêmica, a não compreensão da inter-relação de tudo desses professores indicam uma visão mais básica, fragmentada da natureza.

Esse laço é explicado por Gadotti (2000) quando afirma que o amor pela Terra não é aprendido em livros e sim com a experiência individual no convívio com a natureza, afinal o gosto decorre do conhecimento e este requer uma relação próxima com o que se deseja valorizar.

\subsubsection{Projeto Leitura e Percepção Ambiental Pelas Trilhas do Parque}

Este projeto está vinculado ao Curso de EA aos educadores, de forma que estes professores, após a realização do curso, retornam ao Parque com seus alunos para o trabalho de percepção socioambiental nas trilhas e piscinas.

Algumas das dificuldades deste projeto é angariar fundos para o transporte e lanche das crianças (as escolas não podem arcar com estas despesas) e incentivar a participação dos jovens do entorno da área do Parque tanto nas trilhas como em eventos ambientais. Para isso são estabelecidas parcerias. 
A importância das trilhas interpretativas consiste em revelar o que passa desapercebido pela nossa percepção. Ao passarmos por um área verde sem atenção ou com a cabeça ocupada, não reparamos na riqueza daquele local. Quando nos inserimos neste ambiente com o propósito de conhecê-lo passamos a escutar e quem sabe até ver os animais que ali se encontram, as características únicas e diferenças entre as árvores, o bem estar gerado, o barulho da água, vento, é possível identificar os elementos do local.

Segundo Vasconcellos (1997), a interpretação ambiental é um mecanismo de tradução da linguagem natural para a linguagem humana. Este processo gera o encantamento necessário para criar uma ligação entre as pessoas e o espaço, fazendo com que este passe a compor o mundo dessas pessoas e seja procurado quando desejado, ou seja, inicia-se o processo de pertencimento àquele local, que desencadeia a preocupação com o mesmo e a pré-disposição ao conhecimento. Este tipo de prática é considerado por Peralta (2002) como sendo o mais eficiente estímulo individual à conexão ambiental.

A dificuldade quanto ao trabalho com a percepção está no fato dela acontecer individual e internamente. Ou seja, as sensações de cada indivíduo (captadas pelos cinco sentidos: visão, olfato, audição, paladar e tato) irão definir ou nortear os valores e ações quanto ao meio, formando a compreensão do mundo ao redor do indivíduo permeado pelo seu contexto social, ético, cultural e econômico (MELAZO, 2005).

Outro fator importante é a informação passar primeiro pelos professores, que então irão conduzir seus alunos pela trilha, repassando as informações recebidas no curso dos educadores, de forma compatível ao nível de compreensão desses alunos.

\subsubsection{O Parque Vai a Sua Escola}

Visando minimizar os conflitos entre esta UC e seu entorno, que é comum às áreas protegidas de uma forma geral, o NEA do PNB promove ações de aproximação entre escola/parque/comunidade pretendendo a sensibilização e divulgação da causa ambiental são discutidos temas como: o funcionamento de unidades de conservação, caça, pesca, acúmulo de lixo, invasão antrópica e animal.

Aqui a EA é claramente utilizada como instrumento de gestão, sendo escolhida esta ferramenta para gerenciar uma questão prejudicial à unidade, com consequências sérias e diversas que evitam o bom relacionamento do Parque com seu entorno e o cumprimento de seus objetivos. 
Evidentemente é muito difícil resolver todos os problemas apenas com a educação, ainda mais considerando que alguns fatores estão fora do alcance da gestão do parque, como por exemplo: a ocupação da sua zona de amortecimento, apesar de ser plenamente descrita no SNUC. Deste fato, pode-se inferir o descaso com o que as unidades de conservação são tratadas pelo Estado, que não cumpre com suas próprias determinações; no entanto espera que funcione.

\subsubsection{Educação Ambiental Como Instrumento de Prevenção aos Incêndios}

Florestais e Técnicas Alternativas ao Uso do Fogo para o entorno da UC

O fogo é sempre uma questão de preocupação quando se trata de Cerrado, principalmente em áreas de conflito como unidades de conservação. Portanto foi desenvolvido este trabalho com escolas, produtores rurais, entidades e comunidades ao redor do Parque. A ação é orientada no sentido de esclarecer quanto aos danos ocasionados pelo fogo, utilizado em práticas externas, que pode invadir a área protegida e causar desequilíbrio. São promovidos minicursos, oficinas, ciclos de palestras para este esclarecimento e apresentação de técnicas alternativas.

A principal atuação se concentra no Loteamento Boa Esperança, Lago Oeste, Cidade Estrutural, Vila Basevi e Área Nova do Parque. Novamente se faz fundamental a atuação de parcerias e colaboradores para a realização desse projeto; e, mais uma vez, a educação ambiental é utilizada como mecanismo de gestão desta unidade de conservação, visando minimizar os impactos gerados pelo conflito de interesses e atividades no seu entorno.

\subsubsection{Educação Ambiental aos Usuários do Parque}

Os usuários do Parque muitas vezes não tem a consciência do local que estão fazendo uso e nem das consequências de seus atos, como afirma Martins (2013); as pessoas não conhecem o valor ecológico deste espaço. Com o intuito de informar estes usuários, são mantidos pontos de apoio em forma de quiosque na área das piscinas que realizam campanhas educativas sobre os serviços ambientais prestados pelo PNB, o trato dos animais que possam fazer contato (principalmente macacos), a destinação dos resíduos sólidos e a interpretação das trilhas, quando demonstrado interesse.

É importante aproveitar a oportunidade da visitação para incutir nos usuários que o Parque representa mais que uma área de lazer, existindo uma justificativa maior para a sua existência e um benefício social; sendo necessários cuidados simples por parte deles para a manutenção e continuidade da área. 
No entanto, enfrenta-se dificuldade em produzir material para este projeto, precisase de um servidor capacitado para orientar estagiários e voluntários nesse processo de sensibilização, dificultado pela tradicional falta de recursos.

\subsubsection{Atendimento às escolas e visitantes ao CEA}

As escolas que se interessarem podem agendar uma visita ao Centro de Educação Ambiental, assim como visitantes comuns. Eles são conduzidos pelas trilhas interpretativas para a atividade de percepção ambiental.

Este serviço oferecido depende principalmente do interesse do público externo para que funcione e, este ano em particular (2015), foi muito prejudicado pelas greves nas escolas. Em geral, há problemas como a falta de conhecimento deste projeto e o fato de ainda não se ter a cultura de fazer uso dos espaços públicos como extensão do ambiente escolar, no caso. É preciso que se entenda e valorize a utilização das unidades de conservação como ambientes educativos que, além de ser um de seus objetivos, ainda podem suprir a necessidade de espaço e vivências que a escola não pode oferecer.

\subsubsection{Projeto Pesquisa-ação e Elaboração de Materiais Educativos}

Este é um projeto voltado para produção de material educativo e de divulgação das atividades desenvolvidas pelo PNB. Não apenas material para uso dentro na unidade como banners, folders, livretos, vídeos e outros, mas também pesquisas mais aprofundadas como monografias, cursos e relatórios, destacando a importância do trabalho do CEA.

Este projeto demonstra a preocupação do PNB em manter as suas ações, produzindo sempre que possível material para ser utilizado e abrindo suas portas para pesquisas que gerem conhecimento a seu respeito. É importante ressaltar que estas pesquisas devem gerar um retorno para o Parque, seja na forma de reformulação de atividades, estruturação de projetos, sugestões de atendimento ao público, técnicas a serem utilizadas nos cursos, confecção de material, divulgando o trabalho, entre outros.

\subsubsection{Revitalização do Centro de Educação Ambiental (CEA) do NEA/PNB}

Esta é uma ação para manutenção física do espaço do CEA/CV, assim como do material utilizado em suas atividades e mão-de-obra de todos os tipos necessários para o funcionamento do espaço. Além do atendimento às escolas e usuários, o CEA/CV também é procurado para receber eventos de cunho ambiental promovido por entidades governamentais como o ICMBio e o Ministério Público. 
Mais recentemente (2013-2014) foram realizadas as seguintes melhorias:

- Construção/Revitalização do Espaço Verde na área externa do CEA

- Construção de labirinto

- Revitalização da área de exposições

- Manutenção de exposições temática cerrado

- Pintura da maquete PNB com apoio de voluntários

- Plantio de espécies nativas no Bosque dos Visitantes no entorno do CEA e Bosque com parceiras das escolas

- Trilhas adaptadas para simulação perceptiva à baixa visão

- Trilhas ligando a área do Riachinho à Lagoa realizada com parceria

- Revitalização área do Riachinho e Ponte da Ilha da meditação

- Identificação de espécies nativas do cerrado na área do CEA por meio de placas - apoio de voluntários

- Aquisição de equipamentos do espaço interno do CEA

Esta não é uma atividade voltada ao público, no entanto, garante o espaço onde acontecem todos os outros projetos e é feita com extrema dificuldade, sendo relatada pelos funcionários uma grande escassez de recursos financeiros para viabilizar as atividades em questão.

\subsubsection{Projeto voluntário/estagiários}

O objetivo é capacitar voluntários e estagiários para auxiliarem nas atividades desenvolvidas pelo Parque anteriormente descritas, sempre no sentido de construir uma conscientização que garanta a sua sustentabilidade. As funções dos voluntários e estagiários consistem em:

- Apoiar ações educativas na área das piscinas

- Apoiar na organização do banco de dados do NEA

- Apoiar na elaboração de projetos para a racionalização dos espaços interno do CEA, com vista a inclusão e acessibilidade

- Apoiar nas atividades educativas no entorno do PNB

- Apoia no atendimento às escolas no CEA, trilhas do Parque

- Apoiar na produção de materiais didáticos 
A equipe de educação ambiental é muito reduzida, sendo necessário mais mão-deobra tanto no NEA quanto na unidade; sendo assim é fundamental o trabalho de estagiários e voluntários para a continuidade dos projetos.

\subsubsection{Projeto de Identificação de Espécies Arbóreas Nativas na Área de Visitação}

Este projeto consiste na identificação das árvores que se encontram ao redor das áreas de maior uso e visitação do Parque, inclusive as trilhas, sendo afixada nelas uma placa com seu nome científico e popular, além de outras informações gerais para que seus usuários e visitantes conheçam um pouco as árvores presentes no PNB. Esta é uma demanda solicitada pelos professores que utilizam o espaço do parque para atividades educativas com seus alunos.

Informações a respeito das árvores sempre foi uma porta aberta para o encantamento do público em geral. Mesmo que seja a título de curiosidade, sempre é demonstrada admiração por este conhecimento. Estas não são informações de difícil acesso, e é uma atividade que pode ser praticada em qualquer escola, tanto com alunos quanto com professores; promovendo o despertamento para o interesse ambiental e podendo ser trabalhado de forma transversal no currículo escolar.

\subsubsection{Curso de Formação Socioambiental para Ilícitos Ambientais e Urbanísticos}

O público alvo deste projeto são infratores ambientais e urbanísticos encaminhados pelo Ministério Público do Distrito Federal e Territórios - MPDFT.

Aqui o intuito é a sensibilização dos infratores quanto à proteção do meio natural para manutenção da vida, saúde e qualidade de vida, relacionando a natureza com sociedade e cultura. Os resultados deste projeto tem se mostrado bastante positivos, não indicando reincidência e gerando a procura por outras instituições ao longo de seus dez anos de funcionamento, segundo informado pelo NEA.

Estão compreendidas aqui infrações que vão desde pichação pública a caça de animais silvestres, sendo atendidas $16 \mathrm{~h}$ do seguinte conteúdo:

- Conceitos básicos de educação ambiental (sustentabilidade e pegada ecológica);

- Introdução Bioma Cerrado;

- Introdução à legislação ambiental;

- Descritivo do PNB;

- Prevenção dos incêndios florestais; 
- Principais problemas ambientais (Filme Aquecimento Global 8' e Ecopercepção temática fogo);

- Conhecimento e interpretação de sensopercepção (trilha Capivara e visita a área de uso público);

- Atividade de campo conhecimento do uso e ocupação do solo em torno do PNB;

O conteúdo referente à legislação ambiental foi ministrado por um policial militar do batalhão da Polícia Militar Ambiental (BPMA) da Candangolândia-DF, que abordou o tema de forma bem didática, deixando espaço para participações do grupo (Figura 2).

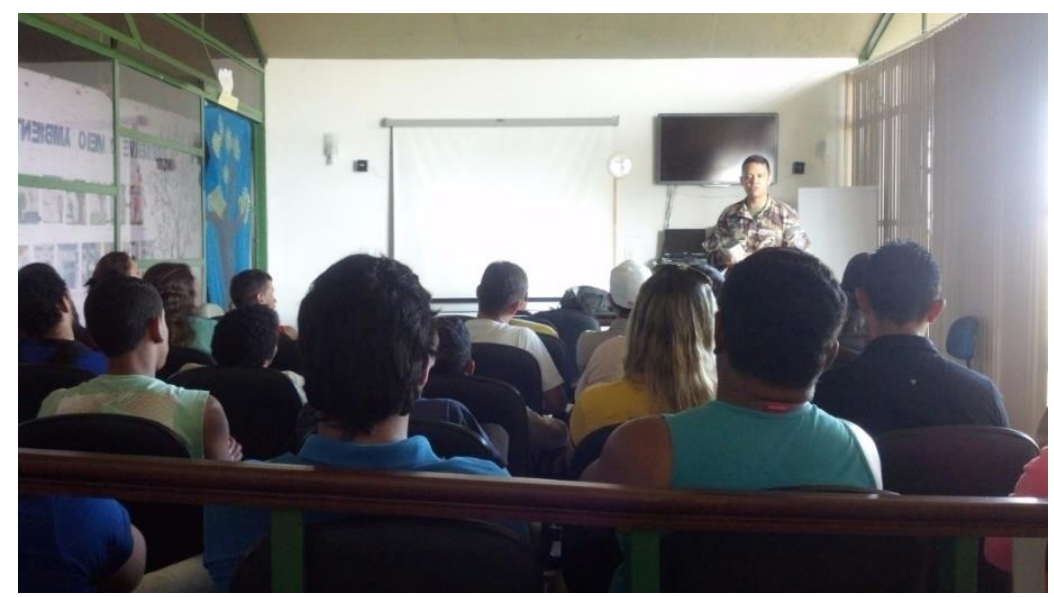

I - Figura 2. Aula expositiva com Instrutor da Polícia Ambiental. Fonte: Arquivo pessoal da autora.

Martins (2013) realizou um estudo sobre este curso e apontou a revolta de seus participantes ao afirmarem estarem sendo punidos por ações que não julgavam ser ilícitas, alegando o desconhecimento da lei. No entanto, no Brasil, a legislação está disponível para o conhecimento de todos e é um dever de todo cidadão o seu conhecimento. Seria interessante para o Estado tornar a legislação mais próxima da população, favorecendo a informação, trabalhando de forma preventiva e não punitiva, como vem sendo trabalhado, afirma Wollf (2000); de forma que o Estado define atos e fatos lesivos e apresenta as punições.

As atividades práticas do curso consistiram em percorrer de forma interpretativa a trilha da Capivara e uma visita ao lixão da Estrutural. A dinâmica da trilha interpretativa consiste em revelar o que se encontra adormecido pela insensibilidade dos cinco sentidos, acostumados ao meio urbano. A sua importância consiste na ressignificação não apenas do espaço da trilha ou do Parque e sim do ambiente natural como um todo, expondo a dinâmica encadeada de funcionamento dos elementos presentes. 
É visível a expressão de surpresa, em diferentes níveis, nas pessoas que fazem o percurso; no entanto, essa experiência funciona como uma etapa inicial, sendo necessárias atividades complementares.

Quanto a visita ao popularmente chamado lixão da Estrutural (Figura 3), localizado em uma cidade assentamento de mesmo nome, dentro do ônibus foram dadas as explicações pertinentes: as pessoas daquele local estão em situação de vulnerabilidade, não gostam de serem fotografadas e, caso alguém não queira descer do ônibus não será obrigado. Até a chagada ao lixão da Estrutural, todos estavam bem falantes, ao entrar na cidade os olhares já começaram a ficar mais curiosos e surpresos, se perguntando como as pessoas moram em um local como aquele, sujo e desorganizado.

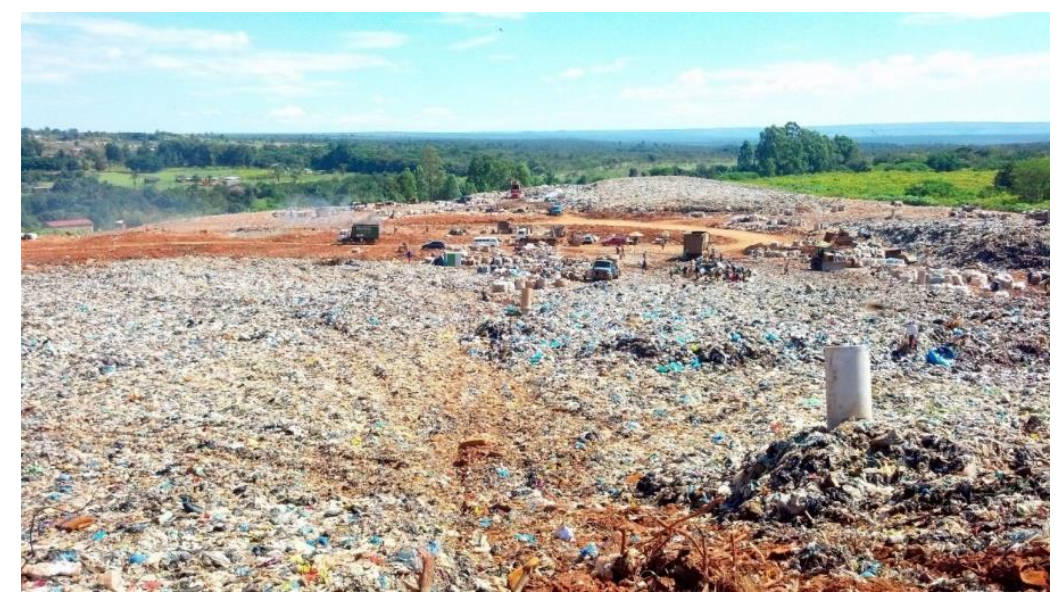

I - Figura 3. Vista do Lixão da Estrutural observada pelos apenados. Fonte: Arquivo pessoal da autora.

Já no lixão da Estrutural, a visita foi guiada por um funcionário local (com experiência de 29 anos de lixão), que apresentou o local, o tipo de lixo que é encaminhado para lá, a quantidade de lixo doméstico (entre 2.000 e 2.700 ton/dia) e a seleção que é feita. Após a separação do lixo para aproveitar o que for possível (como plástico e alumínio), o restante é enterrado, formando uma pilha de 40 metros de altura, atualmente. São instaladas anilhas para liberação e queima dos gases produzidos que, além de ser uma fonte de energia desperdiçada, funcionam como uma bomba relógio; e a quantidade de lixo é cada vez maior.

Este lixão se encontra em um dos limites do PNB, sendo circundado também por áreas de agricultura e nascentes, de forma que a decomposição do material contamina estes locais. Além deste problema é possível avistar uma quantidade muito grande de urubus e carcarás se alimentando dos rejeitos, o que é extremamente prejudicial ao equilíbrio ecológico do parque, pois estes animais deixam de cumprir suas funções 
ecológicas na área preservada, como por exemplo o controle biológico de roedores e carcaças.

O retorno à sede do Parque aconteceu de forma mais silenciosa, pensativa, demonstrando comoção pelas pessoas que vivem naquela situação. Foi aberto um espaço para aqueles que desejaram dividir a sua experiência com o grupo e foram demonstrados sentimento de revolta por serem obrigados a visitar o lixão da Estrutural e também um sentimento de compreensão à prática. A maioria concordou que foi uma vivência importante para a sensibilização e de muito aprendizado. No entanto, ao serem indagados se haveria alguma mudança de comportamento a partir de agora, foram poucos os que se manifestaram, ficando clara uma postura de passividade, uma mudança atrelada a uma condição "se" (se fossem vendidas sacolas coloridas no mercado para separação de lixo, por exemplo). Foi ressaltado, ainda, que é preciso sair da zona de conforto.

Evidentemente, ainda há muito que ser trabalhado neste grupo. Não foi demonstrado uma postura ativa quanto à questão ambiental e à compreensão do processo em cadeia de nossas ações; no entanto, o objetivo de sensibilização, que trata especificamente de ilícitos ambientais, parece ter sido atingido pela aceitação do conteúdo e práticas demonstrada pelo público, além de não ser mais possível alegar o desconhecimento da lei.

É sempre complicado intervir na relação de um indivíduo com seu meio. Sobre isso Turene (2006) diz que para a análise dessa interação é necessário conhecer como acontece o processo de conhecimento, a linha de raciocínio (cognição), o tipo de sensações e emoções envolvidas (afetividade); e finalmente como se deu a conexão com o meio por meio da cognição e afetividade. Concordando com esta afirmação, Ribeiro (2003) coloca que o pensamento e comportamento de cada um são modificados a medida que se modificam os laços que o ligam ao seu contexto. Sendo assim a prática de interpretação ambiental se torna uma ferramenta fundamental na ressignificação do ambiente e na transformação dos laços já existentes com o meio.

Para Vasconcellos (1997), o processo de responsabilização dos atos praticados em experiências como esta acontecem por meio de uma linguagem e abordagem dinâmicas relacionadas às atividades e ao contexto de cada indivíduo. Apesar de não constar na Lei de Crimes Ambientais (Lei ${ }^{\circ}$ 9.605/98) a EA tem sido utilizada como alternativa na sensibilização de infratores e como ferramenta de prevenção. 


\subsection{Dados extraídos a partir do questionário estruturado aplicado à equipe de educação ambiental}

Importante ressaltar que o conteúdo desse tópico tem como fonte os funcionários da unidade de conservação estudada. Todos responderam a um questionário de quatro perguntas subjetivas que, apesar de buscar respostas específicas, permitiam a discussão de tópicos julgados convenientes por parte dos mesmos.

É um consenso entre os Técnicos que compõe este grupo de trabalho que a educação é um processo contínuo, podendo estar presente em qualquer atividade, seja ela formal ou informal, acarretando um efeito em cadeia de reflexão crítica, autonomia e emancipação com vistas à mitigação dos impactos antrópicos ao meio ambiente, sociedade e economia principalmente.

Somada à falta de recursos humanos (apenas três funcionários, dos quais um é voluntário) para ministrar os cursos, realizar o atendimento nas piscinas, receber os visitantes, existe uma séria falta de recursos financeiros para confecção de materiais, estruturar os projetos entre outros, obrigando os funcionários a, algumas vezes, investir do próprio bolso no trabalho que acreditam e a dependerem de doações.

Para o desenvolvimento das atividades os responsáveis recebem um treinamento em São Paulo, capital, na Academia de Biodiversidade (AcadeBio), exceto a funcionária com função administrativa.

Um ponto de extrema relevância observado foi a desconexão da gestão ambiental pública nos diferentes órgãos, uma vez que não se comunicam entre eles; e o fato dos cargos serem ocupados por pessoas de diferentes formações acadêmicas/técnicas, somada a rotatividade dos cargos, prejudicando a continuidade das parcerias formadas, sem contar não haver uma verba destinada especificamente para este fim.

Foi apresentada uma visão pessimista da Legislação Ambiental que, apesar de aparentemente ser considerada importante não é construída com participação efetiva dos diferentes núcleos da população, quando "o que acontece de fato são representações, faltando à sociedade o autêntico exercício da cidadania. É afirmado, ainda, que o País apenas se desenvolverá quando passar a responder por si mesmo, tendo na educação, em todas as suas formas, a ferramenta para esta emancipação”.

\section{CONCLUSÃO}

Apesar do estudo de caso ter sido aplicado a apenas uma das atividades desenvolvidas, pode-se afirmar que o programa de EA atinge como um todo seu 
público. Todo trabalho do NEA foi descrito e é aplicado a um público muito variado, abrangendo como um todo o público do PNB.

As metodologias de sensibilização utilizadas no Curso de Formação Socioambiental para Ilícitos Ambientais consistiram n apresentação do conteúdo teórico, incluindo a Lei de Crimes Ambientais, e duas atividades práticas, trilha interpretativa e a visita ao Lixão da Estrutural.

A prática da percepção ambiental, presente de alguma forma em todas as atividades realizadas, se mostra fundamental para despertar o sentimento de pertencimento à natureza, para incluir o ambiente do Parque no mundo dos participantes do programa, esclarecendo quanto às finalidades e seu real propósito. Além da ressignificação deste e outros espaços também possibilita a modificação dos laços que ligam os infratores ao ambiente. Ou seja, o que antes não parecia ter importância ou gerar consequências agora pode passar a ter um valor suficiente para que seja preservado.

A procura pelo programa de EA, não é pouca; no entanto, a divulgação desse trabalho e o incentivo à sua participação seriam de grande valia, seja para os participantes que fazem parte da vivência, seja para o PNB que tem a oportunidade de sensibilizar um número maior de pessoas e o próprio Estado.

A formação de parcerias é destaque na viabilidade do programa, principalmente considerando a falta de recursos tanto humano quanto financeiros.

Apesar do PNB estar completando cinquenta anos ainda existem conflitos no seu entorno que acarretam em prejuízo para o seu funcionamento e manutenção de sua biodiversidade, como o uso do fogo, a caça, invasão de animais domésticos, descarte de lixo, agricultura, a presença do lixão da Estrutural em um de seus limites e outros fatores diversos.

O grupo de trabalho do NEA, composto pelo coordenados, uma agente administrativa e um voluntário de outra área do Parque, se mostra capacitado para desenvolver este programa de educação ambiental, superando todas as dificuldades e se desdobrando para garantir o funcionamento de todos os projetos. $\mathrm{O}$ entendimento de educação ambiental desta equipe consiste em seu conceito atual, contextualizado socioambientalmente, buscando um processo contínuo de raciocínio e aprendizagem que levem o indivíduo a conquistar a sua emancipação e a atuar positivamente em seu contexto.

Um demonstração desta capacidade é o cumprimento do objetivo de sensibilização ambiental dos ilícitos encaminhados pelo Ministério Público do Distrito Federal. Esta 
afirmação é feita, com base na observação dos participantes e das respostas dadas ao final do curso na sua avaliação. Foi demonstrada, de uma forma geral, uma compreensão das práticas realizadas, a importância de ter passado por aquelas experiências e o que mudou a partir delas.

\section{BIBLIOGRAFIA}

BRASIL. Lei no 9.605, de 12 de fevereiro de 1998. Dispõe sobre as sanções penais e administrativas derivadas de condutas e atividades lesivas ao meio ambiente, e dá outras providências. Diário Oficial da União [da República Federativa do Brasil], Brasília, DF - 13 de fevereiro de 1998, Página 1 (Publicação Original). Seção I.

BRASIL. Lei no 9.795, de 27 de abril de 1999. Dispõe sobre a educação ambiental, institui a Política Nacional de Educação Ambiental e dá outras providências. Diário Oficial [da República Federativa do Brasil], Brasília, DF, n. 79, 28 abril 1999, (Publicação Original). Seção I.

BRASIL, Ministério do Meio Ambiente. Secretaria de Articulação Institucional e Cidadania Ambiental. Departamento de Educação Ambiental. Os diferentes matizes da educação ambiental no Brasil: 1997-2007. Brasília, DF: MMA, 2009. (Série Desafios da Educação Ambiental). 290 p.; 21 cm.

GADOTTI, Moacir. Pedagogia da Terra. São Paulo: Pirenópolis, 2000.

GUIMARÃES, Mauro. A dimensão ambiental na educação. Campinas, SP: Papirus, 1995 (coleção Magistério: Formação e Trabalho Pedagógico).

LEFF, E. Saber ambiental: sustentabilidade, racionalidade, complexidade, poder. $6^{\mathrm{a}}$ ed. 494 p. Petrópolis: Vozes, 2001.

MARCONDES, A. C. SOARES, P. A. de T. Curso básico de educação ambiental. Ed. Scipione, São Paulo. 1991.

MARTINS, A. P. Avaliação de metodologias de sensibilização ambiental como instrumento para a formação de multiplicadores ambientais no Parque Nacional de Brasília. Dissertação (mestrado) - Universidade de Brasília, Faculdade de Tecnologia, Programa de Pós-Graduação em Ciências Florestais. Brasília, 2013.

MELLAZO, G.C. A percepção ambiental e educação ambiental: uma reflexão sobre as relações interpessoais e ambientais no espaço urbano. Olhares \& Trilhas. Uberlândia, Ano VI, n. 6, p. 45-51, 2005.

PERALTA, C. H. G. Experimentos educacionais: eventos heurísticos transdisciplinares em Educação Ambiental. In: RUSCHEINSKY, Aloísio. (Org.). Educação ambiental: abordagens múltiplas. Porto alegre: Artmed, 2002. (p. 105-125). 
Plano de Manejo - Parque Nacional de Brasília. Convênio IBAMA - FUNATURA. Sem data.

RIBEIRO, L. M. O papel das representações sociais na educação ambiental. Dissertação de Mestrado, pela Pontifícia Universidade Católica. Departamento de Educação. Programa de Pós-Graduação em Educação. Rio de Janeiro, 2003.

TURENE, A. Crítica da modernidade. 6ª ed., Petrópolis: Vozes, 1999.

VASCONCELlOS, H. S. R. A pesquisa-ação em projetos de Educação Ambiental. In: PEDRINI, A. G. (org). Educação Ambiental: reflexões e práticas contemporâneas. Petrópolis, Vozes, 1997.

Sistema Nacional de Unidades de Conservação da Natureza - SNUC: Lei no 9.985 , de 18 de julho de 2000; decreto $n^{\circ} 4.340$, de 22 de agosto de 2002. $6^{\circ}$ ed. Aum. Brasília: MMA/SBF, 2006. 56p.

TOLEDO, R. F. Educação ambiental em Unidades de Conservação do Estado de São Paulo. 2002. 169 p. Dissertação (Mestrado em Saúde Pública) - Universidade de São Paulo, São Paulo, 2002.

WOLFF, S. Legislação ambiental brasileira: grau de adequação à Convenção sobre Diversidade Biológica. Brasília: MMA, 2000. 88p. (Biodiversidade, 3). 


\title{
CAPÍTULO II: ANÁLISE DOS MÉTODOS DE SENSIBILIZAÇÃO DOS PROGRAMAS DE EDUCAÇÃO AMBIENTAL APLICADOS NA ESTAÇÃO ECOLÓGICA DE ÁGUAS EMENDADAS
}

\section{Resumo}

A Estação Ecológica de Águas Emendadas é um tipo de unidade de conservação de proteção integral em que a visitação é permitida mediante a participação no seu programa de educação ambiental ou de pesquisa. A equipe de educação ambiental desenvolve o curso Reeditor Ambiental voltado para professores e alunos da rede pública, que participam do processo de construção do saber ambiental por meio de atividades diversas, tanto práticas quanto teóricas, baseadas na metodologia NEPSO. Foram aplicados questionários estruturados aos professores e alunos participantes, assim como também aos profissionais responsáveis, a fim de entender as expectativas, dificuldades, entendimento sobre educação ambiental e meio ambiente, entre outros. Ao final, demonstrou-se a importância do preparo dos professores, o preparo da equipe e a forma como as crianças se relacionam e entendem o meio ambiente.

Palavra-chave: Escola, área protegida, capacitação.

\begin{abstract}
The Ecological Station Águas Emendadas is a protected area which can only be visited through its environmental program or research. The area has an environmental education team who promotes the Reeditor Ambiental Course facing teachers and students of the public school system. Who participates of the process to develop an environmental knowledge through different activities both practical and theoretical based on NEPSO methodology. It was applied questionnaires for the teachers, students and the workers to identify which was the expectation, issues, how they see environmental education and others. At the end it was possible to say how important is to prepare the teachers, the capacity of the workers and how children understand and interact with the environment.
\end{abstract}

Keywords: School, protected area, capacitation. 


\section{INTRODUÇÃO}

Desde a criação da primeira área protegida, o Parque de Yellowstone, em 1872, nos Estados Unidos, foi acrescido ao longo do tempo ao propósito de preservar a paisagem a necessidade de proteção por razões científicas, além da criação de outras categorias de áreas protegidas. A criação da União Internacional para a Conservação da Natureza IUCN, em 1948, veio acrescentar ao conceito destas áreas o valor do bem-estar econômico e social da humanidade (FERREIRA, 2008).

No Brasil, as unidades de conservação (UC) são organizadas pelo Sistema Nacional de Unidades de Conservação - SNUC, sendo divididas em dois conjuntos: de uso sustentável e de proteção integral. Dentre as áreas de proteção integral, a criação da categoria Estação Ecológica representou um marco ao ser a primeira a permitir e ter em seus objetivos a realização de estudos ambientais, a participação de órgãos financiadores e de pesquisa na implementação de tais unidades, e trouxe a preocupação com o uso das áreas vizinhas (FERREIRA, 2008).

No Distrito Federal, foi criada, em 1968, a Reserva Biológica de Águas Emendadas, sendo a primeira desta categoria no país. Após quase vinte anos de conflitos fundiários, a reserva passou a ser uma Estação Ecológica (ESEC), prevendo um centro de pesquisas ecológicas com fins educacionais e de pesquisa, contando com 10.547 ha (FERREIRA, 2008). Somada a sua característica quase única de divisor de águas de duas grandes bacias hidrográficas (Tocantins/Araguaia e Platina), a Estação Ecológica de Águas Emendadas (ESECAE) compõe o que se chama de hotspot (área de elevada biodiversidade sob grande ameaça), devido a relevância de sua grande biodiversidade, sendo cenário de diversas pesquisas (FERREIRA, 2008).

Segundo o Artigo $9^{\circ}$ do SNUC, um dos objetivos das Estações Ecológicas é proteger a natureza e realizar estudos científicos, sendo proibida a visitação pública, excetuando-se visitas de cunho educacional obedecendo as especificações do plano de manejo da unidade (SNUC, 2006). A ESECAE está localizada na região administrativa VI, Planaltina-DF, o que gera uma pressão crescente devido ao aumento de loteamentos urbanos, e áreas agrícolas que fazem uso de aditivos nocivos ao ambiente. Esta pressão afeta diretamente a função de corredor de ligação de flora e fauna entre as bacias citadas, além de comprometer a qualidade da água das nascentes que são utilizadas para o abastecimento urbano (FERREIRA, 2008).

A questão hídrica sempre apresentou forte relação com o Cerrado não apenas pelo seu papel de distribuidor deste recurso pelo território sul-americano, mas também por 
abrigar as nascentes de rios de grande importância, o que torna fundamental ações que garantam a preservação deste ambiente. Fica, assim, evidente a relevância desta estação ecológica (FERREIRA, 2008).

O entorno da estação apresenta-se totalmente ocupado por uma mancha urbana crescente, grandes culturas agrícolas e por propriedades rurais, tornando indispensável o monitoramento da região, estudos, pesquisas e envolvimento da sociedade, a fim de evitar danos irreversíveis. Justamente com este intuito, foi construído, em 1996, o Centro de Informação Luís Eduardo Alves de Carvalho, tendo seus trabalhos iniciados no ano seguinte com o curso de multiplicadores ambientais voltados para professores e estudantes do Distrito Federal. Além da introdução à temática ambiental eram realizadas trilhas na área da Estação Ecológica e, com o passar do tempo, acrescentou-se práticas de autopercepção e orientação espacial (FERREIRA, 2008).

Sentindo a necessidade de contextualizar melhor a atividade para a realidade da UC, em 2000, alterou-se o nome do curso para Reeditor Ambiental, conceito que remete a empoderar-se da ação (FERREIRA, 2008). Portanto, contrariando o pensamento que unidades de proteção integral são pouco permissivas quanto a educação e o envolvimento da comunidade próxima, o curso Reeditor Ambiental tem sensibilizado anualmente professores e alunos acerca da proteção do meio ambiente, unidades de conservação e o papel exercido pela ESECAE (ESECAE/IBRAM, 2010).

O diferencial deste curso (Reeditor Ambiental) é o fato de trabalhar com a capacitação dos professores que, segundo Matos (2015), é um campo que precisa de investimentos para que estes sejam capazes de transferir o conhecimento técnicocientífico de forma viável, fazendo uso das salas de aulas e também de ambientes direcionados à vivência ambiental. Em 2006, foi atribuído a este centro de informação o papel de núcleo difusor da pesquisa de opinião (metodologia NEPSO) nas escolas públicas do DF, conferido pelo Instituto Paulo Montenegro e WWF-Brasil.

Fonseca (2008) afirma que as unidades de conservação são ambientes privilegiados à educação ambiental, mantendo sempre em pauta as discussões socioambientais relacionadas. Este capítulo trata da descrição e análise do trabalho de educação ambiental desenvolvido por meio do curso Reeditor Ambiental, promovido e executado pela ESECAE, englobando o seu conteúdo teórico e suas atividades práticas, preocupando-se não apenas com os participantes do curso, mas também com os alunos orientados por estes participantes e a sua equipe responsável. Foi escolhido este curso 
por se tratar de um programa já estruturado, com resultados positivos e abertura para a realização desta pesquisa.

\section{MATERIAIS E MÉTODOS}

\subsection{Caracterização da área de estudo}

A ESECAE localiza-se na cidade de Planaltina, Região Administrativa VI do Distrito Federal, distando aproximadamente $5 \mathrm{~km}$ de seu centro e $50 \mathrm{~km}$ do centro de Brasília. A unidade é formada por dois polígonos, um pequeno, situado entre as rodovias BR-020, DF-128, DF-131, estrada da Caieira e o Córrego Serandi e um grande (Figura 1), cujos limites são:

Polígono maior:

- Limite sul: cruzamento das Rodovias DF-128 e BR-020 até o trevo da DF-345;

- Limite leste: segue pela Rodovia DF-345 até a DF-205;

- Limite norte: segue pela Rodovia DF- 205 até a DF-128;

- Limite oeste: segue pela Rodovia DF-128 até a BR-020.

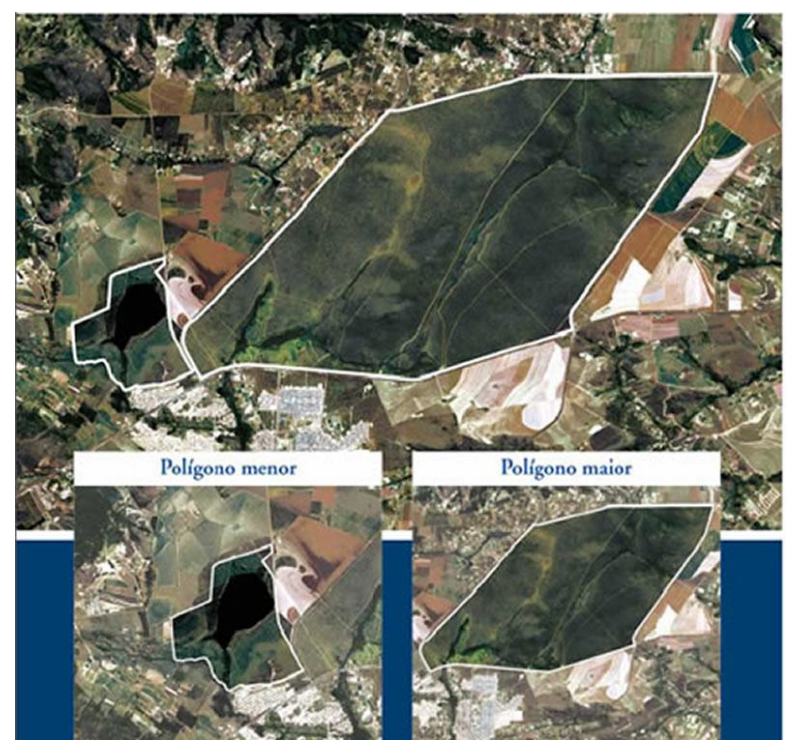

II - Figura 1. Mapa dos polígonos da ESECAE. Fonte: http://www.recursoshidricos.df.gov.br/aguas_emendadas/mapas/003b.jpg

Dentro da estação são encontrados dois tipos climáticos (classificação Köppen) devido a variação de altitude, o Aw: tropical, associado a superfícies dissecadas e Cw: tropical de altitude, associado a altitudes entre 1.000 e 1.200 metros (FERREIRA, 2008). 
Tais características garantem o caráter relevante desta unidade de conservação, sendo uma área de grande interesse para conservação de recursos hídricos, além da flora e fauna do Cerrado que, juntamente com um programa de educação ambiental bem estruturado, fazem da ESECAE o local ideal para aplicação da presente pesquisa.

\subsection{Caracterização do programa de educação ambiental da ESECAE}

Baseada na metodologia aplicada por Martins (2013) no Parque Nacional de Brasília, a coleta de dados desta pesquisa consistiu-se em duas etapas: I) acompanhar as atividades desenvolvidas pela equipe de educação ambiental da Estação Ecológica de Águas Emendadas no programa Reeditor Ambiental e II) aplicação de questionário estruturado para o corpo técnico e os educandos atendidos pelo programa (professores e alunos da rede pública do DF).

Os dados obtidos foram analisados e relacionados com dados levantados a partir de dissertações, artigos, publicações diversas e legislação correlata ao tema de estudo deste trabalho.

\subsubsection{Aplicação de questionário}

Os questionários foram elaborados baseados na metodologia de Martins (2013) e Ferreira (2009), com o intuito de caracterizar os participantes do curso, alunos e equipe de trabalho, conhecer suas expectativas, dificuldades, grau de percepção ambiental e, claro, o seu conceito de educação ambiental.

\subsubsection{Participantes}

Foram elaboradas três perguntas objetivas, simples e diretas para identificar quais as dificuldades encontradas na aplicação da educação ambiental no ambiente de trabalho, quais as expectativas com o curso e como pretende desenvolver seu trabalho no ambiente da ESECAE. O questionário foi aplicado no primeiro dia do curso, tendo sido respondido por 20 professores (Apêndice C).

\subsubsection{Alunos}

Para o trabalho com os alunos dos professores participantes do programa foram feitas onze questões, com o intuito de nortear-se quanto à percepção ambiental das crianças: como elas percebem o ambiente da UC em que estão, a utilização dos recursos naturais, práticas de conservação e da própria educação ambiental entre outros pontos. 
O questionário foi aplicado apenas uma vez, antes da realização da trilha da Lagoa Bonita, justamente para evitar qualquer tipo de influência do conteúdo apresentado e se obter a impressão inicial dos alunos quanto a temática ambiental, apesar deste curso prever atividades também na escola de origem.

Por se tratar de um questionário estruturado, as perguntas eram de múltipla escolha, sendo possível, na maioria delas, a escolha de mais de uma opção de resposta. Ao todo foram respondidos 21 questionários (Apêndice A).

\subsubsection{Equipe de educação ambiental}

Para identificar o perfil da equipe responsável pelo Programa de EA foram desenvolvidas quatro perguntas subjetivas referentes a formação de cada integrante, o tempo de trabalho dentro da unidade de conservação, qual a atuação dentro do Programa e quanto ao treinamento para ministrar as atividades (Apêndice B). Um questionário desta natureza permite a inclusão de outros dados por parte dos respondentes caso desejassem.

\section{RESULTADOS}

Os resultados obtidos consistem na descrição do Programa Reeditor Ambiental em seu conteúdo teórico e na suas atividades práticas como apresentado abaixo. Antes no entanto, é feita a descrição da metodologia NEPSO. Esta metodologia é ensinada aos professores participantes do curso para que estes a apliquem a seus alunos afim de definirem o tema ambiental que será trabalhado por eles ao longo do Curso Reeditor Ambiental.

\subsection{Descrição da metodologia Nossa Escola Pesquisa Sua Opinião - NEPSO}

Este programa é uma iniciativa do Instituto Paulo Montenegro, uma entidade sem fins lucrativos destinada a executar projetos sociais na área educacional. O instituto foi criado no ano 2000 como resultado do engajamento do IBOPE em programas sociais. Seu objetivo é não apenas desenvolver mas também difundir práticas educativas inovadoras, visando principalmente reconstruir o papel de formação da escola pública dentro do seu contexto (Nossa escola pesquisa sua opinião: manual do professor, 2010) (Figura 2).

Para tanto, foi desenvolvido, em conjunto com a organização não governamental Ação Educativa o programa NEPSO, cujo objetivo é tornar a pesquisa de opinião em estratégia pedagógica em escolas da rede pública, apresentando uma possível inovação 
nesta prática envolvendo tanto alunos quanto professores, ultrapassando um modelo cansado que se mostra cada vez mais inadequado.

O manual do programa (Nossa escola pesquisa sua opinião: manual do professor, 2010) aponta como eixo curricular as seguintes premissas indicadas pela UNESCO:

- Aprender a conhecer

- Aprender a fazer
- Aprender a viver

- Aprender a ser

Uma de suas preocupações é em conhecer as pessoas que participam da escola, mas também o que elas pensam e o motivo para pensarem assim, dados que podem ser utilizados como subsídio na construção de novos conhecimentos. Acredita-se que, sendo parte do processo, os alunos aceitam as informações de uma forma mais motivada, comparando a sua opinião com outras e entendendo o processo de formação das diferentes visões de mundo construídas coletivamente com seus conflitos e negociações.

O mesmo manual afirma que a pesquisa de opinião pode ser aplicada em diversos momentos:

- No planejamento da gestão escolar

- No planejamento do processo ensino-aprendizagem
- $\mathrm{Na}$ integração de diversas disciplinas

- Na integração da escola comunidade

- Na contextualização dos conteúdos das disciplinas

Para que haja movimentação do conhecimento adquirido, os envolvidos comunicam-se por meio do site www.ipm.org.br e também são realizados encontros locais, estaduais e internacionais.

\subsection{Descrição do Programa Reeditor Ambiental}




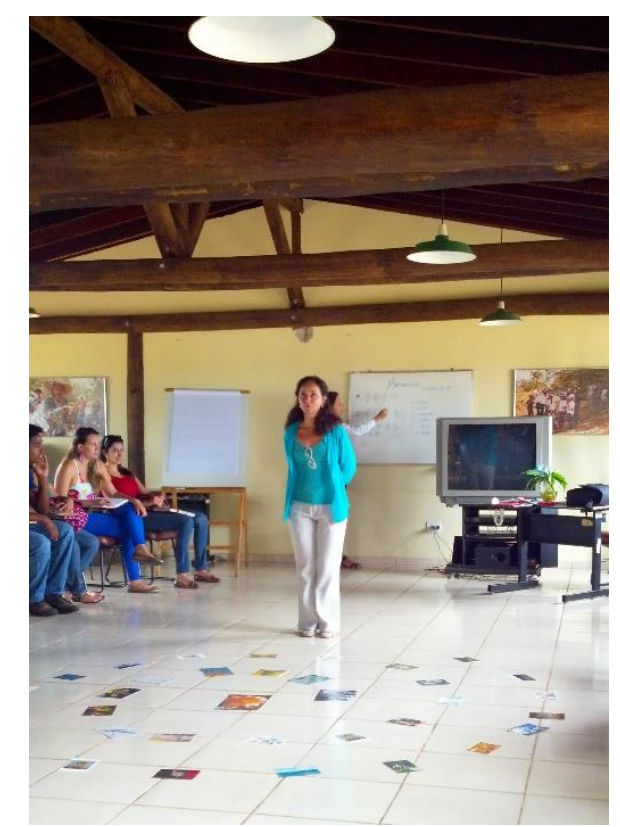

II - Figura 2. Abertura do Curso Reeditor Ambiental no Centro de Informação da ESECAE. Fonte: Arquivo pessoal da autora.

Este tópico tem como fonte a observação e descrição do Programa Reeditor Ambiental, ou seja, o acompanhamento das atividades desenvolvidas.

A Estação Ecológica de Águas Emendadas, segue duas linhas de atuação quanto à prática da educação ambiental: a vertente da educação formal por meio do curso Reeditor Ambiental e a vertente não formal que consiste na educação das comunidades do entorno, sendo fundamental a formação de parcerias para a sua realização.

São realizadas trilhas monitoradas dentro da área da Estação, cujo objetivo parte do pressuposto que perceber e conhecer o espaço em que se está inserido desperta a relação de pertencimento e gera uma ligação emocional com o lugar. As trilhas são realizadas tanto com professores e os alunos destes professores participantes do curso, tendo sido atendidos 4.300 estudantes, quanto com instituições públicas, privadas e ONGs, tendo sido atendidos aproximadamente 7.850 pessoas desde a sua criação (informações cedidas pela própria unidade de conservação).

O curso em questão é voltado prioritariamente para os professores da rede pública de ensino do Distrito Federal, no entanto suas portas estão abertas a todos os que procuram. Seu propósito maior é fortalecer o educador ambiental, formar grupos de trabalho nas escolas e aprimorar os projetos e a qualificação dos docentes.

O curso Reeditor Ambiental existe desde 1998, tendo realizado entre 2004 e 2013 84 projetos NEPSO, formado 202 professores reeditores de escolas da rede pública do DF, contando com a participação de 03 escolas particulares, além de outras instituições 
de pesquisa, ensino, órgão público e outros. Juntamente com o trabalho de formação também foram publicadas cinco revistas de educação ambiental da ESECAE, com a participação dos professores do curso relatando a sua experiência e outros dezenove pesquisadores e professores parceiros da UC (informações cedidas pela própria unidade de conservação).

Importante salientar que a metodologia NEPSO é utilizada dentro do Curso Reeditor Ambiental como forma de identificar os interesses dos alunos participantes e, a partir disso, definir qual o tema central do trabalho desenvolvido ao longo do Curso.

Segundo consta no programa do curso na edição de 2015 o objetivo geral deste é: “Aprimorar a atuação do educador no espaço escolar, incentivando-o e qualificando-o a realizar projetos de educação ambiental que visem à conscientização e preservação do meio ambiente, com vista a ações concretas de intervenções socioambientais". Visa promover o protagonismo juvenil nos cuidados com o meio ambiente, sendo assim, todos os cursistas, até mesmo os professores que não estão em regência, devem eleger uma turma, para que, juntos, trabalhem a metodologia NEPSO.

Os temas abordados no curso são:

- Ecologia Social

- Bioma Cerrado

- Questões ambientais

- Consumo consciente

- Horta como prática pedagógica
- O lixo como vetor de doenças

- Mudanças climáticas

- Saúde integral

- Pesquisa de opinião (como fazer pesquisa na escola)

- Recursos didático pedagógicos

Apesar dos temas já estarem definidos, há espaço para que sejam discutidos temas de interesse dos professores participantes. Ao todo são 180 horas/aula, das quais 75 horas são presenciais na UC e o restante é desenvolvido pelos professores em sua escola de origem com uma turma de alunos selecionados.

São três os conceitos que orientam o curso, seguindo o pensamento de que influenciamos e somos influenciados pelos outros e pelo meio sem existir uma ordem hierárquica entre os conceitos, pelos quais se busca um desenvolvimento integral do indivíduo e da coletividade seguindo uma linha construtivista:

1. Autoformação: se trata da relação do indivíduo com ele mesmo;

2. Heteroformação: se trata da relação do indivíduo, inserido em um contexto, com o outro; 
3. Ecoformação: se trata da relação do indivíduo com o meio físico em que está inserido.

Já a ecologia social é utilizada para orientação do grupo no processo de construção do conhecimento, de forma que sejam criadas situações de ensino-aprendizagem, havendo uma ressignificação dos papéis de educando e educador. É estimulada a participação criativa dos professores, sendo alternadas atividades individuais e em grupo, atividades corporais, artísticas e intelectuais por meio de técnicas de concentração e desconcentração, interiorização e expansão.

Os participantes do curso são orientados a utilizarem a natureza com um espaço pedagógico, fazendo da ESECAE uma extensão da sala de aula, e também a promoverem intervenções artísticas com a temática ambiental no espaço físico das escolas, a revigorar seus espaços verdes.

Ao final do curso é realizado um congresso local chamado Congresso Reeditor Ambiental, onde as crianças apresentam uma peça teatral com o tema ambiental escolhido e trabalhado por eles na escola durante todo o curso. Hoje o congresso se encontra na sua $12^{\circ}$ edição. Além da apresentação, ao longo do curso cada professor desenvolve paralelamente em sua escola, com a turma de alunos selecionados, a produção de um portfólio com todo o tipo de informação referente a um tema de interesse daquela turma baseado no contexto da escola.

Apesar da beleza do projeto a UC enfrenta muitas dificuldades, entre as quais podese citar a necessidade de ampliação da equipe de EA, consolidar a rede de parcerias, reforma das instalações e a aquisição de transporte para os grupos de visita. Outro ponto que vale ser citado é o fato das educadoras que ministram o curso, apesar de serem pedagogas e trabalharem diretamente com educação, não recebem a mesma gratificação que os professores do ensino formal em sala de aula, pois o MEC não considera essa prática como ensino, de acordo com as facilitadoras.

Ambas são professoras concursadas da Secretaria de Estado de Educação do Distrito Federal e, por meio de um convênio com o Instituto Brasília Ambiental (IBRAM), o órgão gestor, desenvolvem o trabalho na unidade de conservação.

\section{Atividades práticas}

\subsubsection{Dança Circular}

Neste tipo de dança existe a figura do focalizador, responsável por conduzir a dança com o intuito de promover a integração entre as pessoas do grupo movimentando-se de 
forma circular em uma grande roda. São ensinados os passos a serem seguidos juntamente com o significado da música e coreografia. Um objeto é colocado no centro da roda para que os participantes se foquem nele enquanto dançam, concentrando-se nos movimentos.

O objetivo desta atividade é a integração do grupo. É uma das primeiras atividades a serem realizadas justamente para que os indivíduos comecem o curso tendo algum tipo de contato com o grupo.

\subsubsection{Automassagem}

Para a realização desta técnica as responsáveis pelo trabalho de educação ambiental receberam um treinamento junto a Secretaria de Saúde do Distrito Federal (Figura 3).

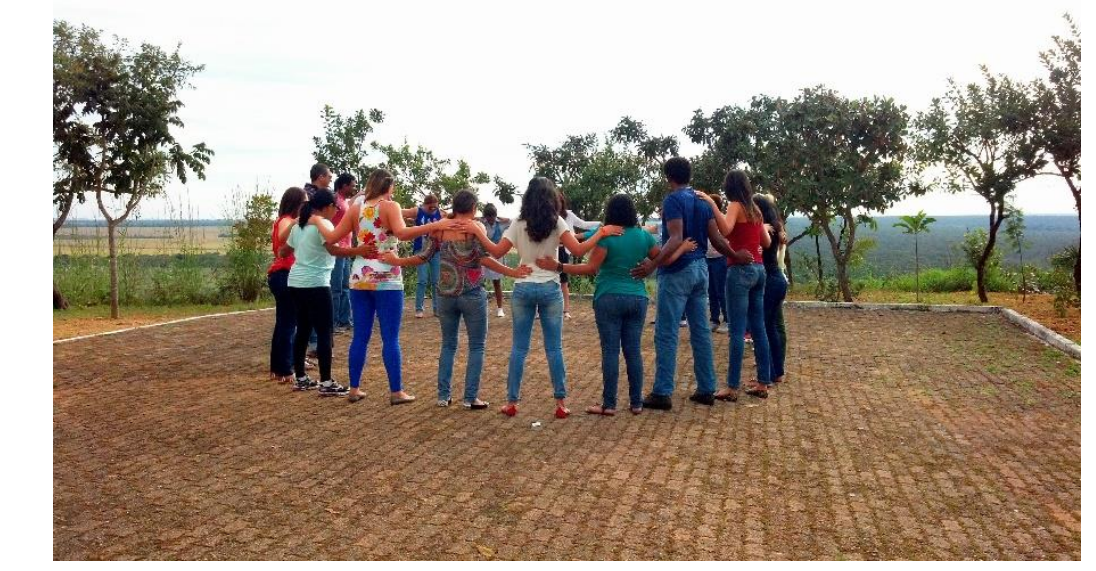

II - Figura 3. Prática de automassagem do Curso Reeditor Ambiental na ESECAE. Fonte: Arquivo pessoal da autora.

Buscou-se esta prática por acreditarem promover o despertar do corpo, aumentando a consciência corporal dos participantes e aguçando a sua autopercepção e, por conseguinte, a percepção externa do meio em que se encontram. A automassagem é realizada tanto com os professores do curso Reeditor quanto com os alunos destes professores antes do início das atividades previstas na ESECAE.

\subsubsection{Trila da Lagoa Bonita}

Esta atividade é iniciada com uma roda do lado de fora do Centro de Informação com práticas de respiração e automassagem, pois acredita-se que a percepção do próprio corpo é o início do contato com o ambiente em volta, aguça os sentidos (Figura 4). Em seguida, é feito um exercício de orientação pelo sol, identificando norte, sul, leste e oeste, observando o que se encontra em cada direção, as estradas, os relevo (iniciando a fala sobre a responsabilidade hídrica inerente a ESECAE), a cidade de Planaltina-DF. 


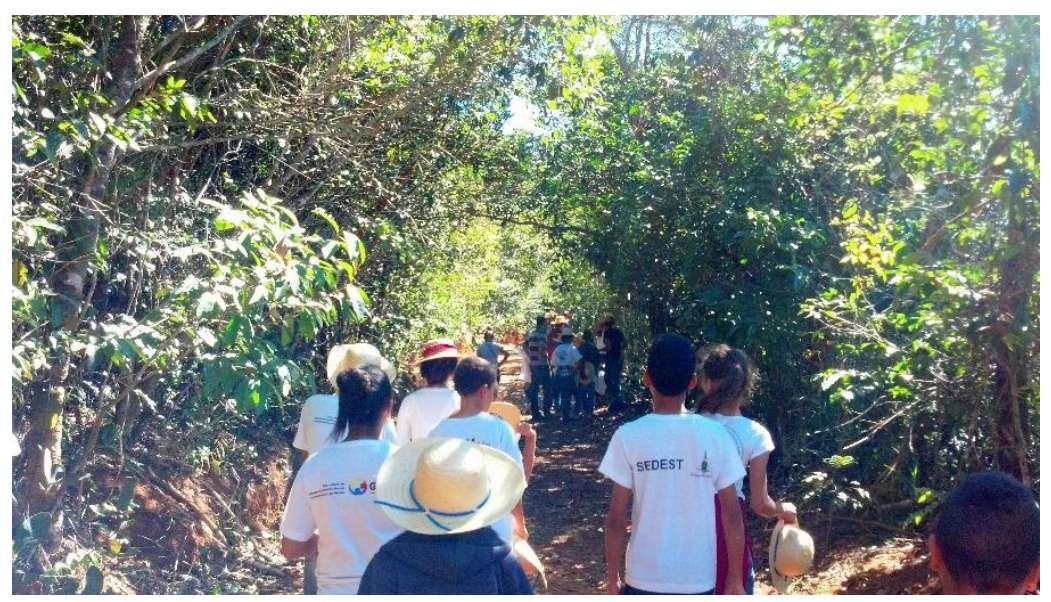

II - Figura 4. Foto da trilha da Lagoa Bonita realizada com os alunos participantes do curso Reeditor Ambiental na ESECAE. Fonte: Arquivo pessoal da autora.

Finalizado o exercício os alunos são encaminhados para o salão do Centro de Informação onde analisam o mapa da UC e região, buscando identificar os pontos referenciados na atividade anterior, introduzindo a discussão sobre o entorno, já todo modificado por áreas rurais e urbanas localizadas na zona de amortecimento da Estação, prejudicando o seu funcionamento e, consequentemente as pessoas.

A segunda parte da experiência é feita na margem da Lagoa Bonita, os alunos são transportados por uma van e divididos em grupos de onze para melhor aproveitamento, sendo designado um guia para cada um. Antes do início da trilha as crianças são orientadas a não jogarem lixo no chão, a falarem baixo e o mínimo possível, a não arrancarem nenhuma planta e que estão entrando na casa dos bichos, portanto estes devem ser respeitados.

Cada guia tem a sua característica pessoal de conduzir a trilha, no entanto é sempre pontuada a inserção no bioma Cerrado e citados os outros existentes, além da explanação acerca das diversas fitofisionomias do Cerrado, sendo demonstradas ao longo da trilha as presentes no percurso e a diferença de funcionamento e adaptação entre elas, mudança do solo, temperatura.

Atenta-se para a grande biodiversidade do local, que são estudadas e conhecidas muitas espécies enquanto outras ainda não se conhece e já são ameaçadas por espécies invasoras, como a braquiária. São apontadas algumas plantas medicinais, a fartura e beleza que perdura por todo ano neste bioma, é demonstrada a estrutura de uma flor completa, comentando-se sobre adaptação e evolução.

Apesar das plantas serem de mais fácil acesso, apresentarem diferentes cores, texturas, utilidades, o maior interesse demonstrado pelos alunos foi na possibilidade de 
encontrar animais no caminho, pensando primeiramente em mamíferos ou animais de grande porte.

Segundo Nelson (2012) a interpretação ambiental é uma ferramenta que contribui para otimizar a experiência que os visitantes podem ter nas UCs, fazendo com que eles tenham uma vivência mais rica e agradável. Ainda segundo esse autor durante a visita, o aprendizado se dá não somente sobre a unidade, mas também sobre o papel da conservação no mundo, o que pode influenciar nas mudanças de atitudes e valores, assim como é uma ferramenta de manejo e pode ajudar o gestor da UC.

Importante esclarecer que todas as atividades, dança circular, automassagem e a trila são realizadas tanto com os professores quanto com os grupos de alunos.

\section{DISCUSSÃO}

\subsection{Programa Reeditor Ambiental}

Guimarães (1995) aponta a individualização como sendo o cerne da problemática ambiental existente, levando a uma desconecção do homem com o meio natural. A partir desta afirmação é possível dizer que esta falta de sintonia impede que as pessoas relacionem seus atos com as suas consequências, perdendo a compreensão do todo e se desresponsabilizando de suas atitudes.

$\mathrm{Na}$ contramão da individualização estão as atividades em grupo praticadas pela ESECAE, que visam a integração de seus componentes, ativando a preocupação com o outro e desenvolvendo o raciocínio sistêmico do desencadear das ações individuais no grupo, esperando-se uma mudança de comportamento dos mesmos.

Quanto à mudança de comportamento, Layrargues (1999), afirma que caso a transformação não ocorra a nível mental, ou seja, uma alteração raciocinada, define-se apenas como um adestramento, não apresentando nenhum resultado efetivo. A partir daí, começa-se a perceber a importância de se investir na capacitação dos educadores, pois estes são os modelos responsáveis pela orientação dos então educandos que, à medida que crescem, ganham mais autonomia e poder de atuação, e devem contar com a questão ambiental não apenas como um conteúdo de escola, mas sim como um estilo de vida.

No entanto, muitas são as dificuldades enfrentadas. A clássica falta de recursos financeiros e humano para custear e desenvolver as atividades do programa, o que acarretou na suspensão da publicação da revista Educação Ambiental, da própria unidade. A manutenção e continuidade do projeto está vinculada à formalização de 
parcerias público privada, mas esbarra na burocracia da formalização das mesmas, além da falta de interesse neste tipo de investimento, acredita-se. Há escassez de recursos não apenas para este campo, mas também na manutenção da estrutura da unidade e material de trabalho.

Associada a essa questão, o não reconhecimento pelo MEC das atividades de ensino das educadoras que realizam o curso, visto que não estariam em ambiente educacional formal (segundo relato das educadoras), acarreta numa perda salarial para as mesmas, o que torna desmotivante a adesão de novos professores pela falta de reconhecimento da carreira.

Fato interessante que merece atenção especial, pois, segundo consta na Lei $\mathrm{n}^{\circ}$ 9.795/99 - Política Nacional de Educação Ambiental, o ensino não-formal está previsto como demonstrado nos Artigos $2^{\circ}$ e $13^{\circ}$, que também demonstram a conformidade do trabalho desenvolvido:

“Art. $2^{\circ}$ A educação ambiental é um componente essencial e permanente da educação nacional, devendo estar presente, de forma articulada, em todos os níveis e modalidades do processo educativo, em caráter formal e não-formal."

"Art. $13^{\circ}$ Entendem-se por educação ambiental não-formal as ações e práticas educativas voltadas à sensibilização da coletividade sobre as questões ambientais e à sua organização e participação na defesa da qualidade do meio ambiente." (BRASIL, 1999)

Os alunos que compõem o grupo selecionado pelo professor participante do curso Reeditor são diferenciados dos alunos de professore não participantes que visitam a ESECAE, pois são capacitados por meio de projetos simultâneos em suas escolas, como pesquisas, elaboração e execução de peça teatral e produção de um portfólio. Além disso são capazes de compreender e aproveitar melhor a atividade proposta pela Estação, além de demonstrarem interesse pela trilha da Lagoa Bonita e o conteúdo discutido, segundo observado pelas orientadoras do Programa.

Investindo na capacitação dos professores e atuando em conjunto com os alunos, promovendo atividades que interferem e transformam o ambiente escolar fazem deste um programa integrador que tem alcançado resultados continuados, inclusive com a participação recorrente de professores que já haviam feito o curso.

O fato de aplicarem técnicas de intervenção voltadas à questão ambiental no espaço da escola permite que as crianças desenvolvam um projeto próprio, que reflete o que foi assimilado do esforço empregado, funcionando inclusive como uma forma de avaliação 
do programa. Além disso, as crianças estão criando vínculos emocionais com aquele espaço em que interferiram, o que assume-se estreitar os laços dos alunos com a escola e entre si, beneficiando também os outros alunos não participantes e a própria escola.

Araujo (2014) aponta que a educação seguia uma linha desenvolvimentista, com vistas ao desenvolvimento econômico, no entanto esta pode funcionar tanto como um aparelho ideológico de reprodução quanto como de transformação social, tendo na educação ambiental uma forte alternativa ao sistema de ensino formal (CUBA, 2010).

Alinhada a estas afirmações, a linha construtivista de atuação da equipe está em consonância com o atual conceito de educação ambiental, que deixou de considerar apenas a ecologia e passou a integrar o contexto socioambiental com o intuito de promover a mudança de comportamento por meio da construção de um conceito relacionado aos envolvidos de forma participativa e crítica, conforme afirma Carvalho (2006).

Além disso, o projeto está de acordo com o estabelecido na Carta de Belgrado como sendo os seis objetivos de atuação da EA: 1. Conhecimento, 2. Conscientização, 3. Participação, 4. Comportamento, 5. Competência e 6. Capacidade de avaliação (REIGOTA, 1994). Complementando esta recomendação, Sato (1999) diz que a elaboração de um projeto deste tipo deve considerar o contexto em que está inserido. Para auxiliar na contextualização dos projetos a metodologia NEPSO se monstra fundamental, pois como descrito, aplica a pesquisa de opinião nas escolas, identificando qual o interesse dos alunos para desenvolver os trabalhos propostos.

\subsection{Análise dos questionários}

\subsubsection{Alunos}

A turma de alunos em que foi aplicado o questionário foi a selecionada por um professor participante do curso Reeditor Ambiental para desenvolver o programa do curso, contando com crianças de diferentes faixas etárias. Optou-se por proceder antes da realização da trila da Lagoa Bonita para partir do ponto zero, sem a influência da experiência da trilha e das informações que foram apresentadas. Foram analisados 21 questionários cujos gráficos referentes às respostas seguem abaixo.

A primeira questão busca perceber se as crianças tem consciência do que é a Estação Ecológica de Águas Emendadas e demonstrou que 15 das 21 respostas apontaram ser um local para proteger a natureza e 10 identificaram como local voltado à educação, que são dois dos objetivos de uma estação ecológica. As outras duas opções 
não são atividades previstas para uma unidade de conservação de proteção integral como pode ser observado no SNUC e representam ideias equivocadas no imaginário das crianças, mas este é um conceito que possivelmente será modificado ao final do programa (Figura 5).

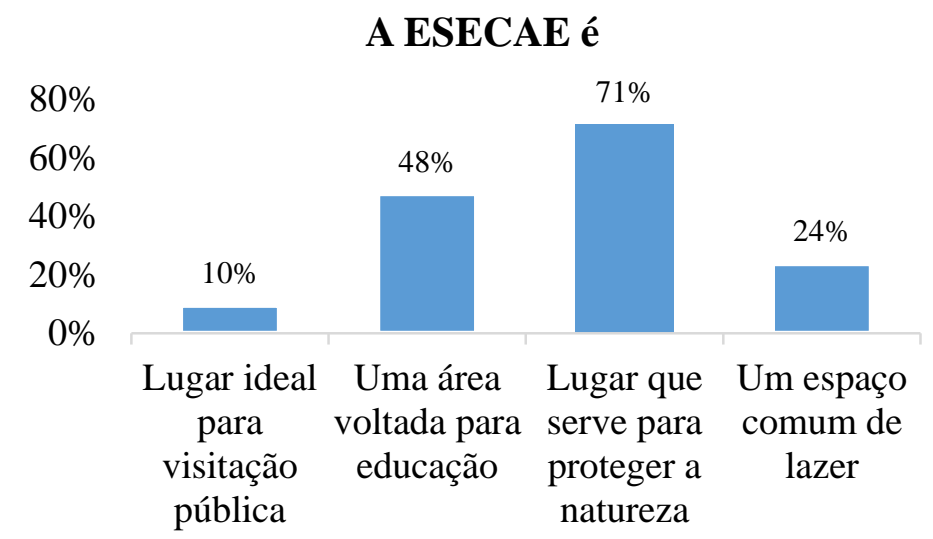

II - Figura 5. Percentual de respostas a primeira questão do questionário: " Para você o ESECAE é".

Complementando o objetivo da primeira pergunta, esta segunda objetiva identificar se as crianças compreendem a razão da existência de um local como a Estação e qual a interpretação para esta existência que, neste caso, ficou a encargo de ser o local que abriga os animais e plantas com 17 respostas, seguida pela manutenção da qualidade de vida com 9, indicando haver a consciência quanto aos serviços ecológicos prestados à sociedade pela ESECAE e que este precisa ser reforçado (Figura 6).

A ESECAE existe porque

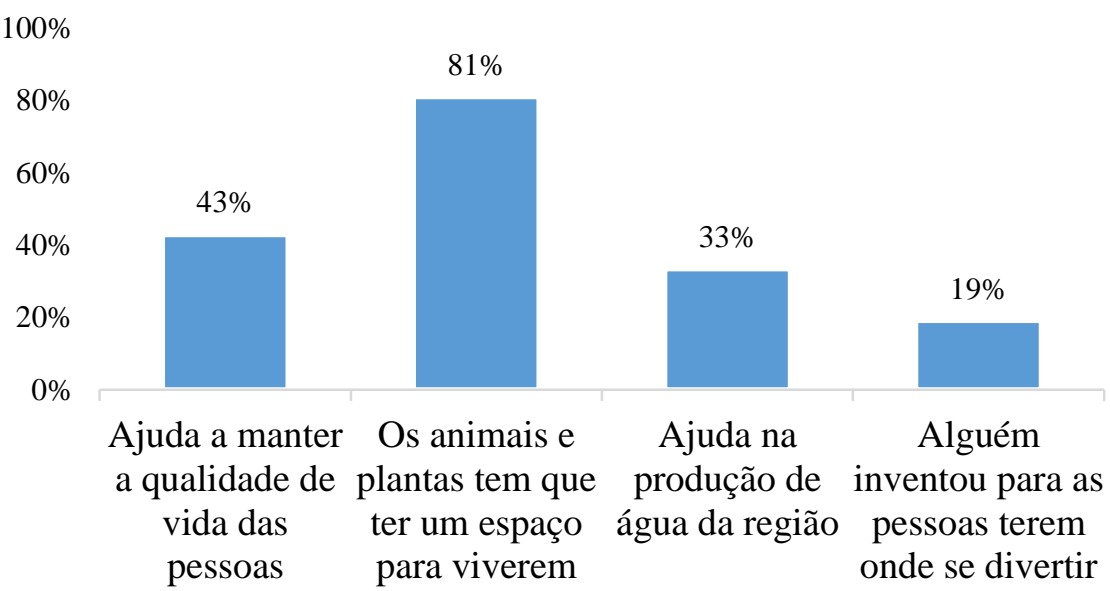

II - Figura 6. Percentual de respostas à segunda questão do questionário: "A ESECAE existe porque"

No entanto, a discrepância percentual entre essas duas alternativas evidencia a percepção que aquele espaço é primeiramente destinado aos animais e plantas, sendo uma consequência os serviços ambientais, o que não é uma interpretação totalmente 
correta visto o caso particular desta estação ecológica, além do fato de não serem questões dissociáveis.

Além do mais, o fato de indicarem ser um lugar específico para os animais e plantas indica haver essa divisão na compreensão das crianças que existe um espaço para as pessoas e outro para os animais e plantas, o que de fato acontece, no entanto é importante se ter a noção que a espécie humana é a mais recente e que para se estabelecer confinou plantas e animais em locais específicos como áreas protegidas, zoológicos, florestas etc.

Apesar de ser a maior justificativa para a existência desta UC, a questão hídrica foi reconhecida por apenas 7 crianças, demonstrando a necessidade do trabalho desenvolvido pela Estação. Quanto aos 4 que disseram ser uma área de lazer, corroboram ainda mais para a importância de ser trabalhar a ESECAE fazendo uso do seu espaço, pois não apenas informa, mas também justifica e internaliza o motivo pelo qual é uma área de proteção e não de uso público.

Novamente tratando da questão do conhecimento à cerca das finalidades desta unidade, esta pergunta informa que, apesar de terem a ciência que a Estação é um local vinculado à proteção da natureza, sendo reconhecida por 17 das respostas, os alunos não entendem o funcionamento da mesma, pois foi observando que apenas 3 estudantes apontaram o seu fim educacional, apesar de estarem na unidade por um atividade escolar. Dado interessante, que demonstra o grau de associação das crianças, deixando evidente que isto não é feito de forma automática, sendo preciso trabalhar o conteúdo de forma simples e clara atentando para a assimilação deste conteúdo (Figura 7).

Visitam a ESECAE para

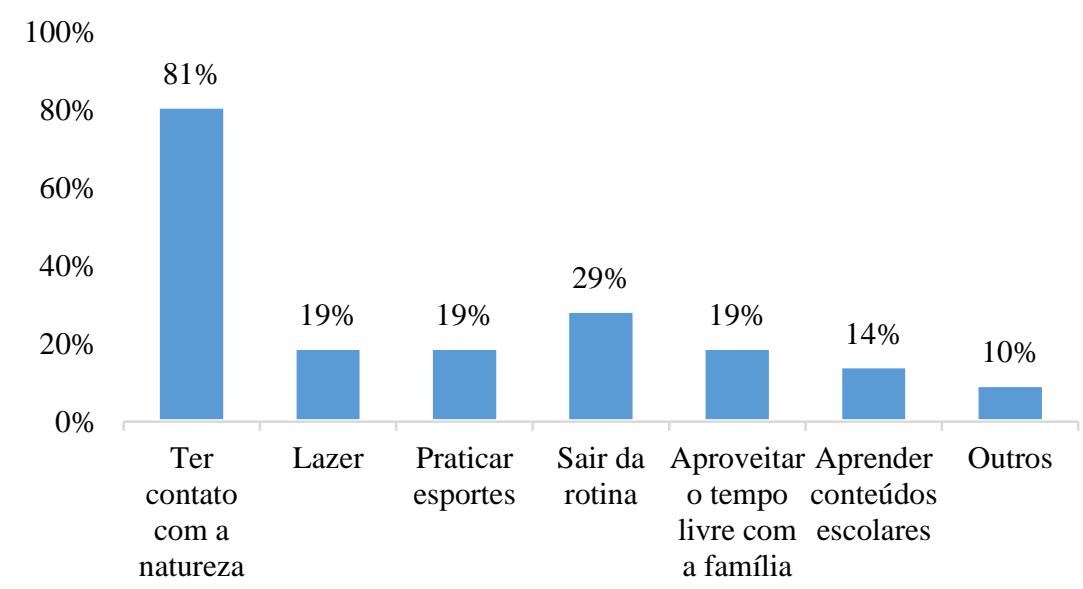

II - Figura 7. Percentual de respostas à terceira questão do questionário: "você visita a ESECAE para" 
Tendo em vista que a ESECAE é uma unidade de conservação de proteção integral e não permite a visitação sem fins educacionais ou de pesquisa, assume-se que as respostas à esta questão foram dadas de acordo com o que as crianças acreditam ser atividades realizáveis na Estação, agregando ao discutido anteriormente sobre a importância de existir um programa de educação ambiental em unidades de conservação.

Os alunos demonstraram grande interesse nos animais, esperando vê-los na trilha da Lagoa Bonita desejando o contato, mostrando que esta pode ser uma porta de acesso ao interesse dessas crianças para a questão ecológica (Figura 8).

\section{Quais animais podem ser visto no Cerrado}

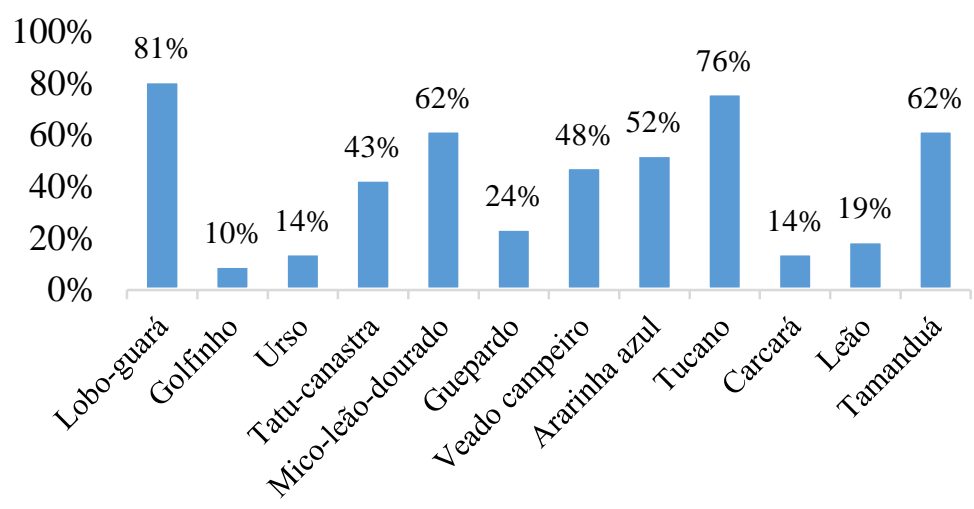

II - Figura 8. Percentual de respostas à quarta questão do questionário: "quais animais podem ser vistos no Cerrado"

As respostas indicaram que o lobo-guará, tucano e o tamanduá foram os três animais naturais do Cerrado mais apontados pelas crianças. Principalmente o lobo e o tamanduá são espécies bandeiras cuja imagem é utilizada na divulgação de projetos e campanhas de conservação da natureza, facilitando a identificação e internalização destes animais pelo público. Já o tucano ainda pode ser avistado mais facilmente em vida livre.

Quanto às outras espécies assinaladas, o golfinho, leão, mico leão dourado também são espécies bandeira que obedecem a mesma lógica, no entanto pertencem a outros ecossistemas, demonstrando que as crianças conhecem os animais, mas não o ambiente ao qual eles pertencem. Fato que evidencia a necessidade e importância de campanhas de conscientização e valorização dos biomas. Apesar das campanhas individuais de conservação de espécies serem fundamentais e de extrema importância, representam uma parte do contexto, gerando este tipo de interpretação de não inserir o animal em seu 
local de origem ou então de se preocupar com a sua proteção apenas e não do seu habitat.

Quanto às frutas do Cerrado os resultados apresentados demonstram serem conhecidas, mas, de forma semelhante ao ocorrido com os animais, conhece-se a fruta, mas não se sabe a origem. As mais comumente encontradas e consumidas, como a goiaba e a banana, são associadas ao Cerrado apenas por serem encontradas no CentroOeste, além da possibilidade de serem encontradas suas respectivas árvores em trilhas pelo Cerrado. Essa informação demonstra mais uma vez a necessidade de se divulgar o Cerrado (Figura 9).

\section{São frutos do Cerrado}

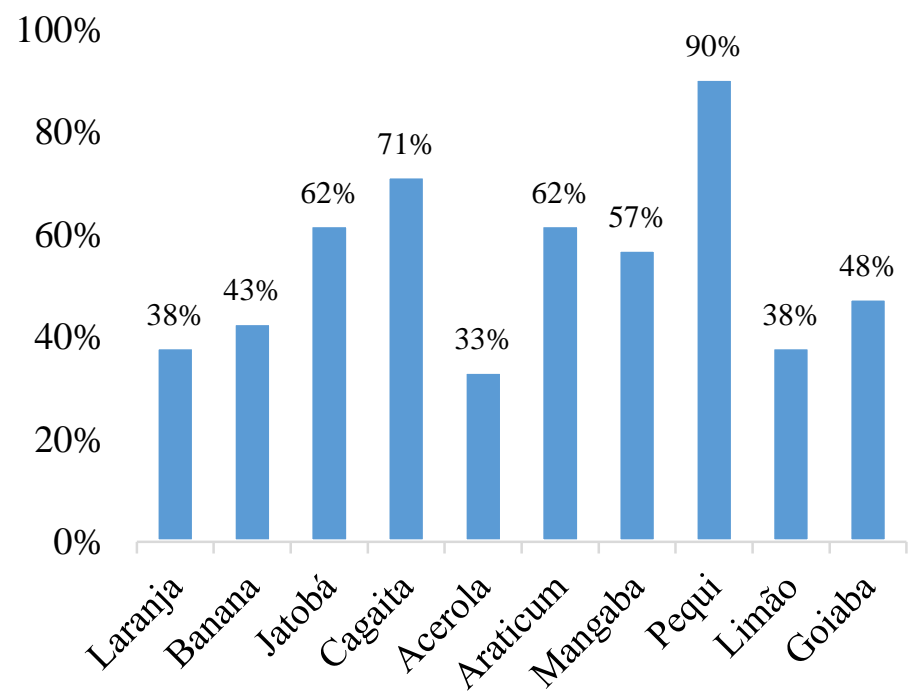

II - Figura 9. Percentual de respostas à quinta questão do questionário: "são frutos do Cerrado"

Para estas duas últimas perguntas, a questão principal é o conhecimento do que é próprio ao Cerrado, por ser o bioma que abriga a região, pois é isto que gera a valorização de seus recursos, buscando-se fazer uso do que é nativo ao invés de preterir o que é externo, ao invés de conservar o que pertence a outros biomas apenas por ignorância do seu próprio hábitat.

Considerando que o maior objetivo da EA é promover uma mudança voluntária de comportamento é importante verificar quais ações as crianças já assumem como ambientalmente corretas para reforça-las e quais conceitos ainda não compõem seu universo para que sejam trabalhados (Figura 10). 


\section{Como proteger a natureza}

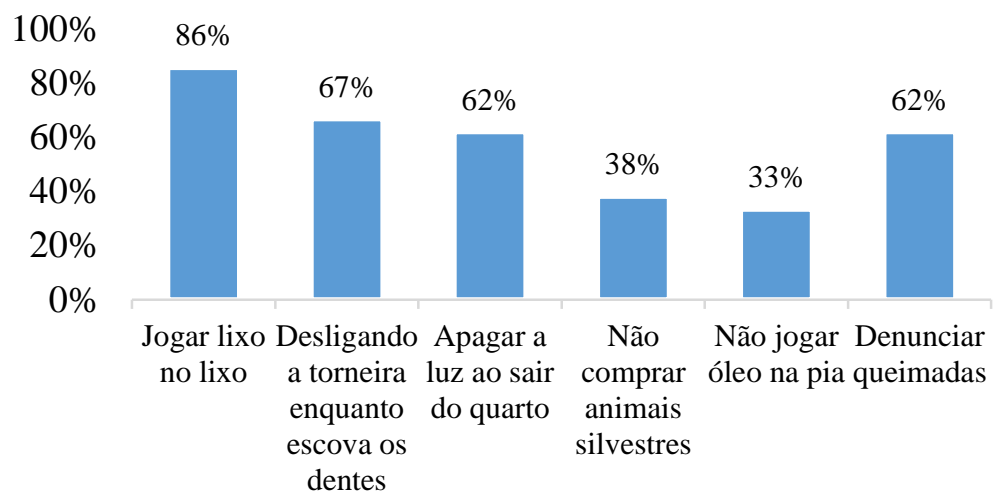

II - Figura 10. Percentual de respostas à sexta questão do questionário: "como proteger a natureza".

Sendo assim, as respostas a esta questão destacaram a ação de jogar lixo no lixo com o maior percentual, 18 respostas, que é o mote da maioria das campanhas vinculadas nos diversos meios de comunicação, escola e dentro de casa. Desligar a torneira ao escovar os dentes (14), apagar a luz ao sair do quarto (13) e denunciar queimadas (13) se apresentaram de forma uniforme, as duas primeiras são atividades cotidianas e de fácil execução, no entanto a percepção do maleficio das queimadas sinaliza o quanto esta está presente na vida destas crianças e como elas já são conscientes quanto a como proceder, o que não implica necessariamente na sua prática.

Quanto a não comprar animais silvestres e não jogar óleo na pia, não é surpresa que tenham apresentado os menores percentuais, uma vez que acredita-se não comporem o universo direto das crianças, com ações educacionais (quando existentes) voltadas para o público adulto. São práticas que extrapolam sua percepção, assim como as suas consequências, apontando uma direção a ser seguida na orientação do trabalho da ESECAE.

Outro ponto relevante quanto nesta discussão é o papel de agentes multiplicadores das crianças, que podem influenciar diretamente os pais passado a compartilhar o que foi aprendido e a cobrar uma mudança de comportamento.

A próxima pergunta buscou identificar qual a visão dos alunos em relação ao meio natural, se é de contemplação (são bonitas), distanciamento, não sendo um local seu (onde mora os animais), relação de uso (itens medicinais), lazer (trilhas) ou então de importância dentro do sistema Terra na manutenção da vida (controle climático) (Figura 11). 


\section{Porque é importante conservar a floresta}

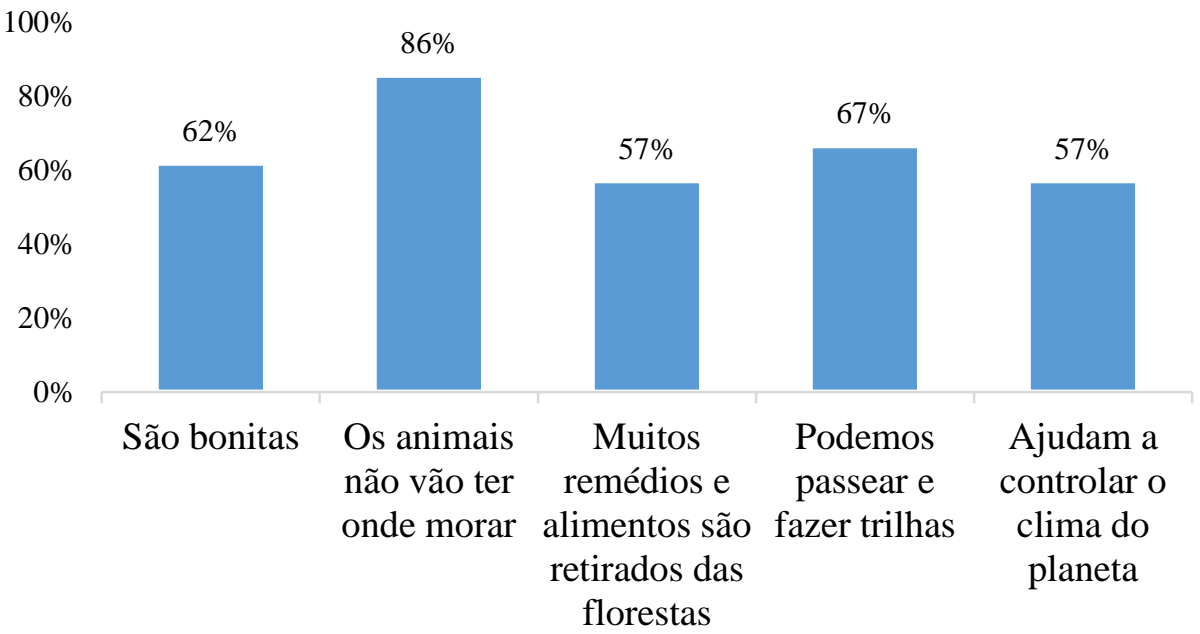

II - Figura 11. Percentual de respostas à sétima questão do questionário: "porque é importante conservar a floresta".

A maioria das crianças, 18, demonstrou certo distanciamento ao colocar o maior motivo para conservação dos animais, o que é de extrema importância, no entanto demonstra a falta do sentimento de pertencimento ao meio natural, a falta de percepção de que o homem, também pertencente ao reino animal, pereceria com a falta das florestas. Lazer e contemplação foram as segundas alternativas mais assinaladas, demonstrando mais uma vez o não pertencimento a este meio, como se fosse uma pintura que se admira em um museu. As duas alternativas que demonstram o sentimento de relação com as florestas foram as que tiveram o menor percentual da questão, 12 crianças, o que não é um número ruim, no entanto evidencia como é necessária experiência de inserção e reconexão com o meio natural.

Em uma pesquisa semelhante, Ferreira (2009), estudando o caso do centro de ensino Polivalente, em Brasília-DF, abordando a mesma questão, demonstrou que as alternativas mais assinaladas foram as referentes ao controle do clima, ao abrigo dos animais e extração de itens medicinais, demonstrando que após a realização da discussão ambiental o conceito sobre floresta sofreu uma mudança, tendo sido acrescido o seu valor de uso pela sociedade e não mais apenas "a casa dos animais", passou a ser um ambiente integrativo às necessidades humanas e não somente a natureza pela natureza.

A oitava pergunta demonstrou que uma das alternativas mais citadas, 15 dos respondentes, foi conhecer as plantas e os animais, o que remete a uma visão antiga da educação ambiental voltada para a vertente ecológica, que se atem aos seus processos 
biológicos. A outra resposta mais citada, com o mesmo percentual, foi perceber que minhas atitudes são importantes para o meio ambiente, o que já está em conformidade com o conceito atual de EA de construir o conhecimento individual para então gerar a mudança de atitude (Figura 12).

\section{Educação ambiental é}

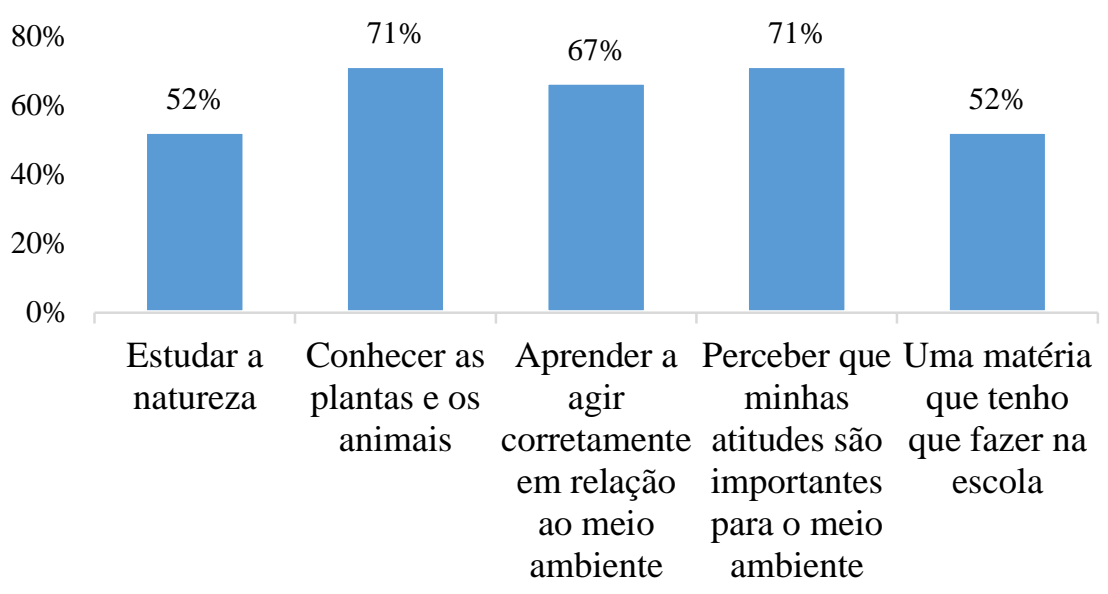

II - Figura 12. Percentual de respostas à oitava questão do questionário: "educação ambiental é".

No entanto, o que torna estes dados interessantes é justamente demonstrar que a visão dos alunos contempla estas duas vertentes que, em realidade, não estão dissociadas. O conhecimento ecológico fornece a base para a experiência ambiental, é onde será inserido o trabalho com o contexto socioambiental.

Importante ressaltar que apesar de muito parecidos, os itens "aprender a agir corretamente em relação ao meio ambiente" e "perceber que minhas atitudes são importantes para o meio ambiente" diferem quando ao conceito de aprender e perceber. O primeiro implica na recepção de informação, que passa a ser conhecida, podendo garantir apenas a ciência do fato e não a mudança de comportamento em decorrência disto, enquanto que perceber implica no reconhecimento da necessidade da mudança após o conhecimento de determinado fato, o que é capaz de gerar a mudança de comportamento pretendida pela educação ambiental e pela proposta do curso.

Por se tratar de uma diferença sutil fica a pergunta se as crianças se deram conta desta diferença. Houve uma pequena diferença entre os percentuais, no entanto não se pode afirmar o que levou a escolha entre um item e outro ou até mesmo de ambos.

As respostas desta questão não apresentaram grande discrepância, e não há resposta errada, portanto, de uma forma geral, o conceito de EA está claro no entendimento dos alunos. 
A nona pergunta trata dos recursos naturais: água, solo, ar, vegetais e animais, que são itens naturalmente associados ao meio natural, de forma que foi demonstrado pelas crianças terem a ciência da origem de tais recursos (Figura 13). No entanto, quando se trata de petróleo e borracha que, apesar de fazerem parte do cotidiano de toda e qualquer pessoa, apresentaram os menores percentuais, 7 e 8 respectivamente em termos absolutos, evidencia-se a falta de conhecimento da cadeia produtiva de ambos e a falta de auto-percepção como usuários diretos destes recursos.

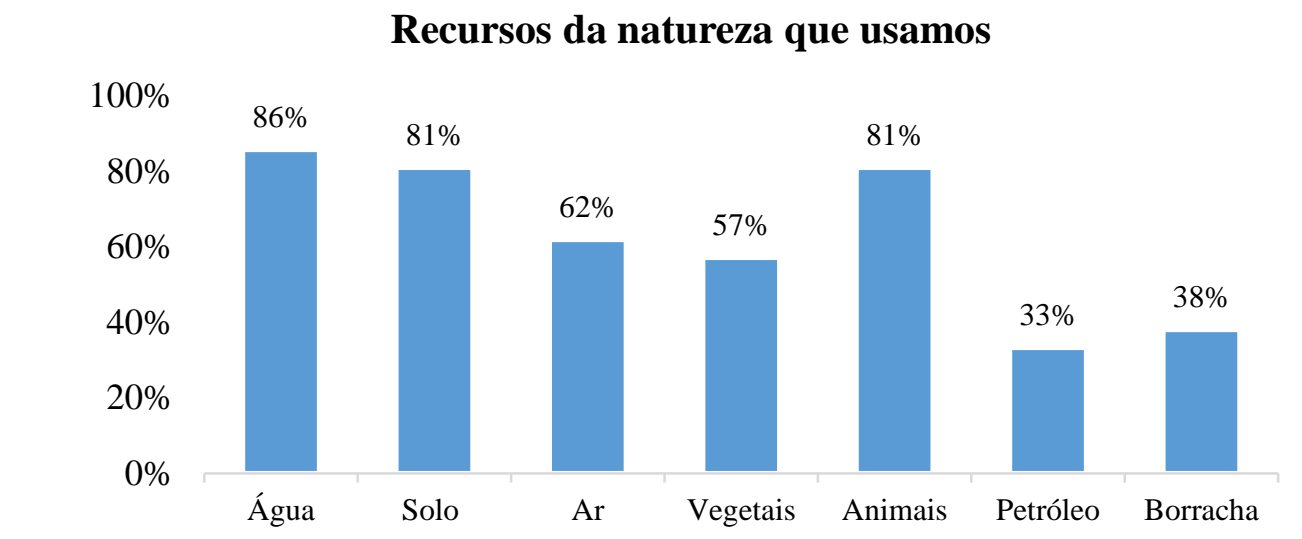

II - Figura 13. Percentual de respostas à nona questão do questionário: "são recursos da natureza que usamos".

O estudo realizado por Ferreira (2009), ao perguntar quais produtos tinham sua matéria prima extraída da natureza constatou que a borracha e a gasolina, assumindo o papel do petróleo, foram assinalados por $81 \%$ e $51 \%$, respectivamente, dos alunos. Diferentemente deste trabalho, o seu questionário foi aplicado após o conteúdo, o que indica, ao menos neste quesito, o cumprimento do objetivo do programa de EA da escola quanto a percepção do uso destes recursos.

Aqui é interessante relembrar a questão da interdisciplinaridade da EA, que rompe com a fragmentação imposta pelo sistema tradicional de aprendizagem, como é discutido por Morin (2000), que coloca a segmentação como um problema por não considerar o contexto do objeto de estudo, criando especialistas nas partes e medíocres no todo, ou ainda conforme afirma Araujo (2014) ao lembrar que o existir humano não é fragmentado. Sendo assim, a importância do caráter interdisciplinar da EA é igualar-se à vida, complexa e inter-relacionada, trabalhando fatos e não teorias (GUIMARÃES, 2007).

A Figura 14 pergunta se os alunos já conheciam a Estação Ecológica antes da ocasião do Curso e a grande maioria, 15, afirmou que não. 


\section{Já conhecia a ESECAE}

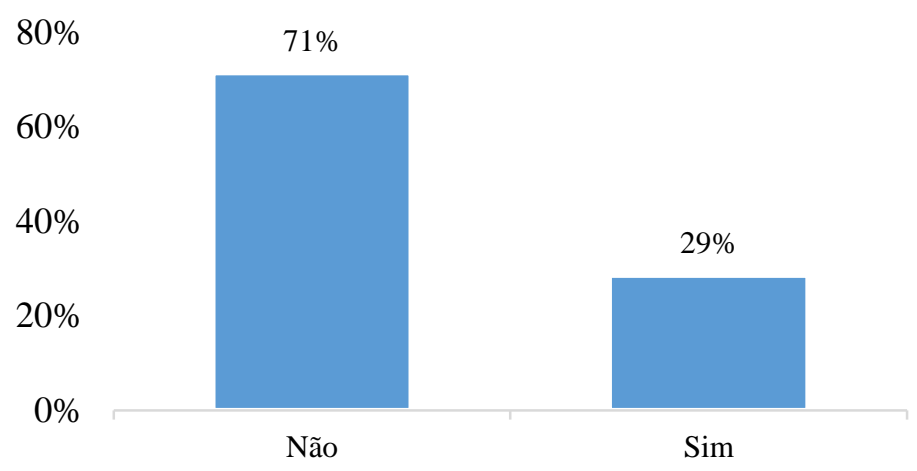

II - Figura 14. Percentual de respostas à décima questão do questionário: "já conhecia a ESECAE".

Considerando que o espaço não é aberto à visitação pode-se inferir que não houve procura por parte das escolas seja para participação no Curso Reeditor ou simplesmente para um trabalho de educação ambiental. Arisca-se dizer que uma dos motivos para isso é a falta de conhecimento sobre o que é oferecido às escolas. (Figura 14).

Seja qual for o motivo, é necessário que seja feita uma maior divulgação sobre o trabalho, tanto da ESECAE quanto das UCs em geral, assim como o incentivo à participação. No próximo item serão discutidos algumas das dificuldades enfrentadas pelos professores.

Fato curioso, que vale a pena ser relatado, é que as pessoas que estão literalmente envolta da unidade não sabem do que se trata aquele espaço, nem ao menos para informar como chegar ao local, não sabem que existe. Apesar de ser uma categoria de unidade de conservação muito restritiva, a boa relação com seu entorno é fundamental para o sucesso na sua gestão e aproveitamento das suas atividades.

Nessa última questão (Figura 15) optou-se por não perguntar apenas se já visitaram outras unidades de conservação por acreditar-se que as crianças não diferenciem estas de áreas comuns, como foi confirmado pelas perguntas efetuadas por elas no momento de preenchimento do questionário. 


\section{Já visitou outra UC/parque}

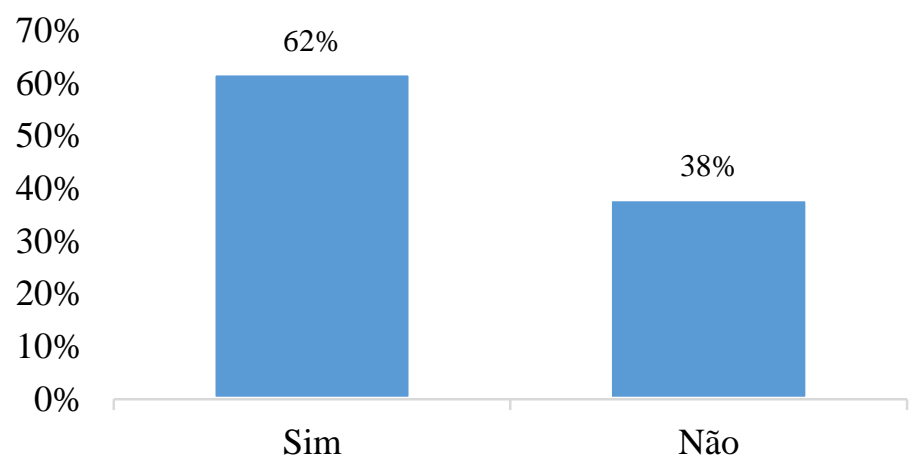

II - Figura 15. Percentual de respostas à décima primeira questão do questionário: "já visitou outra UC/parque".

Apesar da maioria das crianças terem informado conhecer outros parques, um total de 13 alunos, isso representa pouco mais da metade, de forma que poucos são os que buscam estas áreas como atividade de lazer. Os parques mais citados foram o Sucupira, vizinho da ESECAE, sendo de maior proximidade destes alunos, o Jardim Botânico e o parque da cidade.

Aqui fica mais uma vez evidenciado a necessidade de esclarecimento quanto unidades de conservação, suas diferentes categorias, funções e restrições.

O trabalho de educação ambiental voltado para o público infantil é fundamental para criar cidadãos conscientes, poupando o trabalho de reeducar os adultos. Além disso, segundo Branco (2007), as crianças funcionam como agentes multiplicadores e, sendo assim, podem influenciar a família e até mesmo a vizinhança, comunidade ao redor.

\subsubsection{Professores}

Os questionários foram respondidos pelos participantes do curso Reeditor Ambiental edição 2015 que, em sua quase totalidade, se tratavam de professores da rede pública do Distrito Federal, no entanto havia um representante da iniciativa privada, cujas expectativas e intenções com o curso seguem nos gráficos a seguir.

Em todas as perguntas houve a opção “outros" para considerar as particularidades de cada escola, sendo um espaço para que os professores pudessem ser mais específicos, se mostrando uma opção importante para melhor compreensão do quadro, tendo sido utilizada em todas as questões. 
Ao todo eram 20 participantes, sendo este o total de questionários respondidos de forma análoga ao questionário das crianças, ou seja, cada pergunta comportava mais de uma resposta.

A primeira pergunta desse questionário (Figura 16), trata das dificuldades na aplicação da educação ambiental nas escolas.

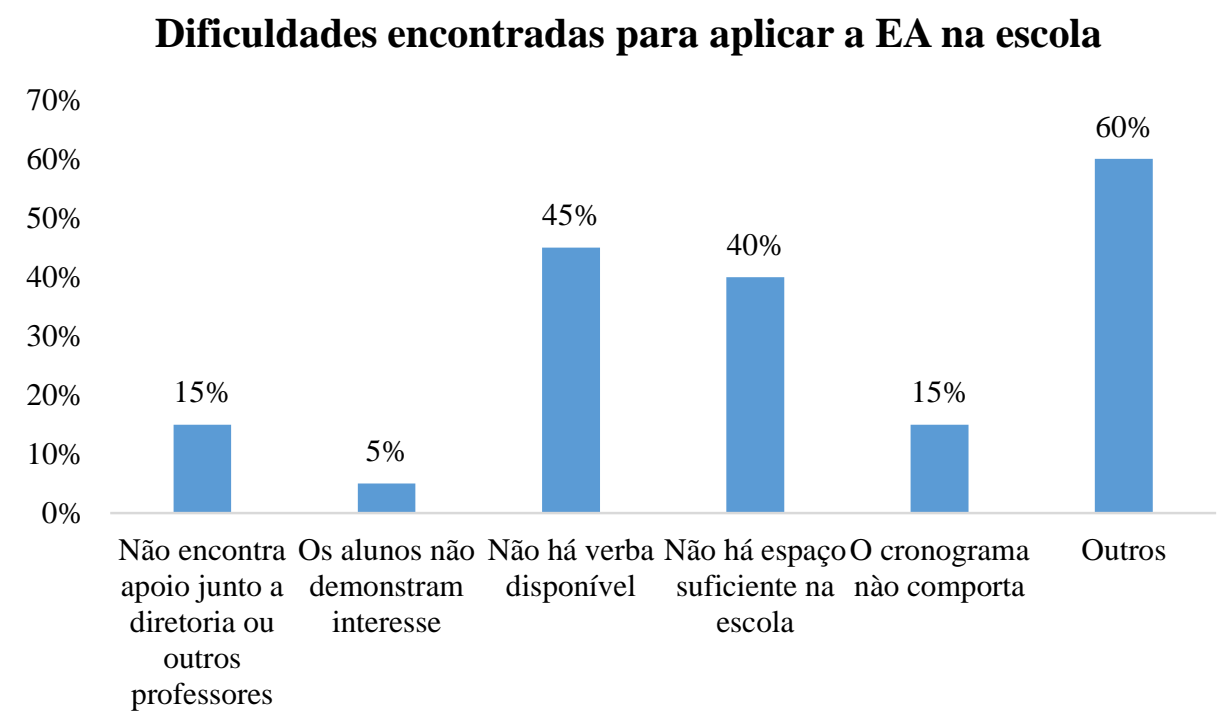

II - Figura 16. Resposta à primeira questão: "Quais as dificuldades encontradas para aplicação da EA na sua escola?"

Falta de verba foi a opção mais comum nesta resposta, 45\%, seguida pela falta de espaço na escola, 40\%, que são fatores limitantes muito comuns mas que não impendem o desenvolvimento de projetos de educação ambiental, salientam a importância de espaços como a ESECAE que fornecem o que a escola necessita.

Os $60 \%$ que assinalaram outros citaram como dificuldades a falta de conhecimento especializado, falta de transporte para os alunos, que a arquitetura das escolas reforça o distanciamento da natureza vivido pela sociedade, falta de propostas de projetos, dificuldade em firmar parcerias com instituições e a não continuidade de trabalhos.

Araujo (2014), entrevistando professores de escolas públicas também de PlanaltinaDF, apresentou um consenso quanto à falta de continuidade dos projetos de educação ambiental, seja por troca do corpo docente ou então por outros motivos diversos, acarretando na perda desta oportunidade ou então estar sempre em processo de estabelecimento, não saindo do mesmo estágio.

A Figura 17 traz o que os professores esperam participando do Curso. 


\section{Expectativa com o curso}

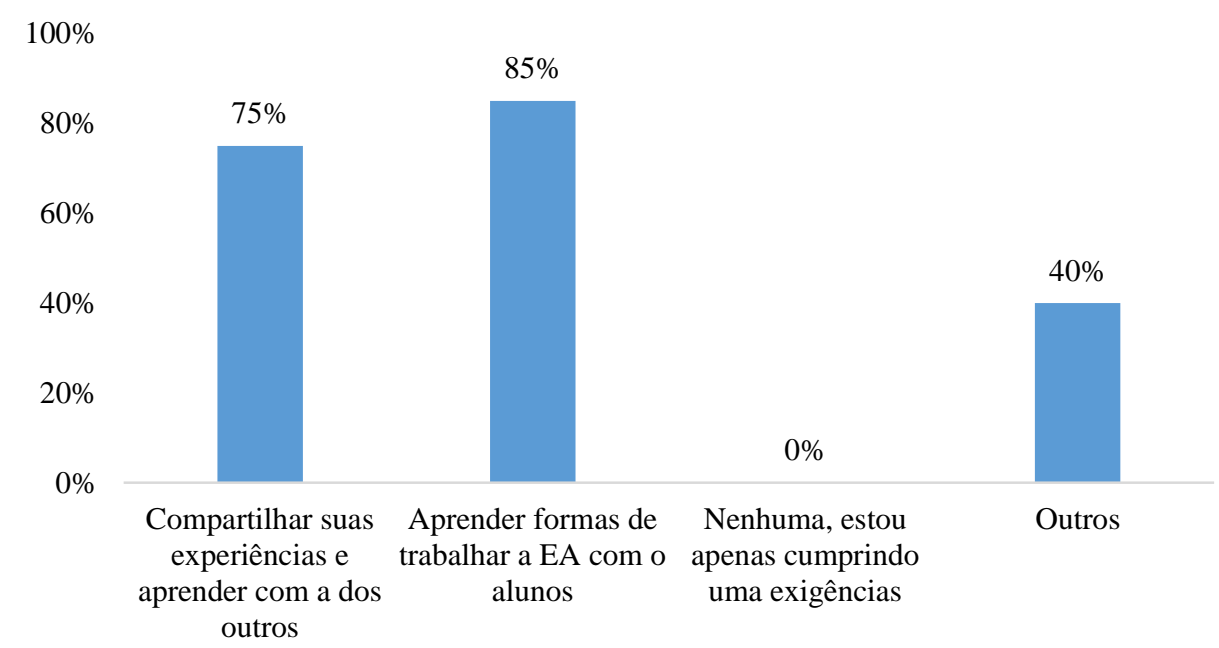

II - Figura 17. Resposta à segunda questão: "Qual a sua expectativa em relação ao curso?"

Segundo o demonstrado no gráfico todos os participantes fazem o curso de livre e espontânea vontade, tendo como objetivo maior aprender como trabalhar a educação ambiental com seus alunos (85\%), seguido pelo desejo de trocar experiências (75\%).

Nesta questão oito professores escolheram a opção outros, representando $40 \%$ dos participantes, de forma que foram apresentados tópicos de cunho pessoal em relação ao curso, afinidade com a natureza, o desejo de repassar para seus alunos e ser uma referência positiva no seu meio social, conhecer o espaço da ESECAE e tornar os alunos multiplicadores, desenvolver trabalhos de horta, jardinagem e coleta seletiva na escola e se reconectar à natureza.

De uma forma geral todos demonstraram, em maior ou menor grau, o desejo desta experiência, sendo um fator muito positivo. Alguns com projetos já estabelecidos outros ainda não, a ideia clássica da horta, da coleta seletiva e trabalho com materiais reciclados que, apesar de válidos, acabam por resumir o trabalho ambiental com crianças, quando em realidade deveria funcionar como atividades meio e não fim, no sentido de despertar para a consciência e atitudes ecológicas. Esta ideia um tanto quanto simplista será ampliada ao longo do curso, sendo agregada, ou ao menos pretende-se agregar, a real dimensão do trabalho da educação ambiental, traduzindo-se na transformação voluntária de comportamento.

A última pergunta, Figura 18, demonstra quais as intenções dos professores no desenvolvimento das suas atividades com as crianças, se já chegam no Curso com uma ideia pré-definida que pode ser melhor desenvolvida. 


\section{Como pretende desenvolver a EA na ESECAE}

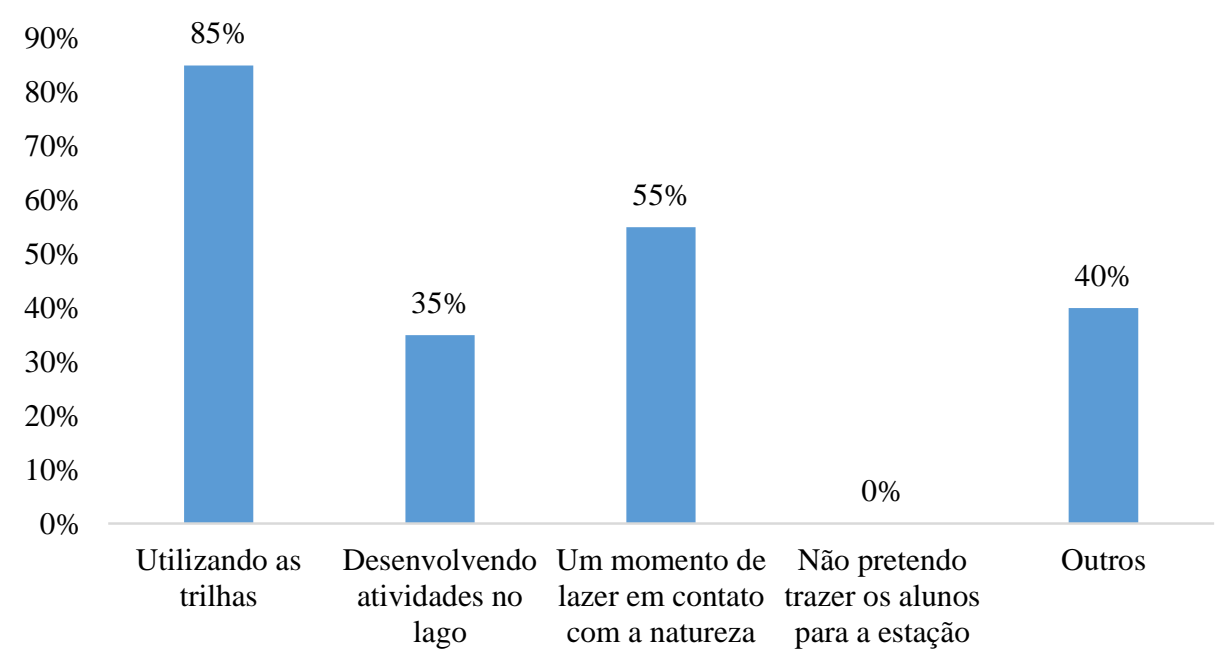

II - Figura 18: Resposta à terceira questão: "Como pretende desenvolver a EA no espaço da ESECAE?"

Felizmente todos os professores pretendem trazer seus alunos para a ESECAE e $85 \%$ deles pretendem fazer uso da trilha, que é a atividade proposta, no entanto, nada impede que outras atividades simples e específicas sejam praticadas desde que compatíveis com a proposta do curso e devidamente autorizadas, como atividades na Lagoa Bonita, que foi escolhida por 7 professores. Quanto aos 11 que também assinalaram um momento de lazer em contato com a natureza, é natural que esta atividade possa ser encarada dessa forma, no entanto não se deve desviar do propósito educacional da atividade, sendo a única razão para a sua prática.

Em relação aos $40 \%$ que escolheram a opção outros, três indicaram a vontade de trazer os alunos para conhecer a Estação, demonstrando desconhecimento do programa do curso que já prevê esta integração. Mais três ressaltaram o contato com a natureza, entre os quais um ressaltou a complementação pelo conhecimento científico e dois manifestaram a intenção de realizar pesquisa e coleta de dados. Apensar de não ser uma atividade impossível, afinal é um dos propósitos que uma estação ecológica, não é o objetivo do curso Reeditor Ambiental, além de haver resrições, sendo necessária autorização mediante apresentação de proposta para que seja feita a coleta de material.

Esta última fala, em geral, demonstra o desconhecimento dos professores em relação ao espaço da ESECAE, evidenciando ser fundamental o trabalho primeiro com os profissionais, para que entendam a proposta e o espaço, e depois com as crianças. 


\subsubsection{Dados extraídos a partir do questionário estruturado aplicado à equipe de educação ambiental}

A equipe é composta por três integrantes, duas educadoras e uma estagiária. Ambas educadoras trabalham na ESECAE a dezessete anos, sendo licenciadas em geografia e artes cênicas, tendo buscado por conta própria formação complementar em educação ambiental, automassagem, taxonomia e morfologia de fanerógamas, dendrologia, ilustração científica, pedagogia social, dança circular entre outros.

Quanto a estagiária, cursa Gestão Ambiental e integrou a equipe a dois meses acompanhando todas as atividades desenvolvidas pela curso Reeditor Ambiental no espaço da Estação.

Como observado a equipe é extremamente reduzida, no entanto altamente especializada e preparada para o trabalho proposto, que é realizado apesar de todas as dificuldades. Algumas delas foram apontadas no questionário como o fato do órgão gestor da ESECAE, Instituto Brasília Ambiental - IBRAM, não priorizar as ações de educação ambiental, ocasionando em condições precárias de trabalho, transporte inadequado das crianças para a trilha e, o fato de maior impacto, a coordenação deste órgão é feita por analistas ambientais e não necessariamente profissionais da área ambiental, que compreenderiam melhor a importância e as necessidades do trabalho e da unidade de conservação.

A questão dos analistas ambientais se dá devido ao fato de não haver restrição quanto a formação dos candidatos nos concursos públicos, dando abertura para que um candidato com uma formação não ligada ao meio ambiente seja responsável por uma área que não seja de seu domínio.

\section{Conclusão}

A oportunidade de acompanhar o curso Reeditor Ambiental revelou um trabalho desenvolvido por uma equipe altamente preparada e interessada em atingir os objetivos propostos e não simplesmente cumprir uma obrigação.

A utilização da metodologia NEPSO se mostra realmente interessante e inovadora.

A criação de vínculo emocional pela transformação do meio constitui uma ferramenta importante para a questão ambiental, pois garante a continuidade do processo.

Outro fato fundamental é a capacitação dos professores, que funcionam como modelo para seus alunos. Além do mais, a sensibilização dos professores e o seu 
preparo contribuem para garantir a continuidade do processo de educação ambiental nas escolas.

Os primeiros três gráficos evidenciam a necessidade de integrar mais as crianças com as unidades de conservação; é incoerente esperar que elas utilizem e protejam estes espaços sem ter conhecimento sobre elas. Projetos como o Reeditor Ambiental da ESECAE constroem um conhecimento ambiental contextualizado, sendo fundamentais para esta proximidade. 


\section{BIBLIOGRAFIA}

Águas Emendadas / Distrito Federal. Secretaria de Desenvolvimento Urbano e Meio Ambiente; Fernando Oliveira Fonseca (org.). - Brasília: Seduma, 2008. 542p.: il. color.

ARAUJO, A. N. Educação Ambiental e Interdisciplinaridade: Um Olhar sobre as Escolas de Planaltina-DF. Monografia. Orientador: Philippe Pomier Layrargues. Faculdade UnB Planaltina, Universidade de Brasília. Brasília - DF, 2014.

BRANCO, S. Meio Ambiente - Educação Ambiental na Educação Infantil e no [vEnsino Fundamental - Oficinas Aprender Fazendo. São Paulo: Cortez, 2007.

BRASIL. ESECAE/IBRAM. Educação Ambiental. Org: Muna Ahmad Yousef, Maria Izabel da Silva Magalhães. Edição Anual. Brasília, 2010.

BRASIL. Lei no 9.795, de 27 de abril de 1999. Dispõe sobre a educação ambiental, institui a Política Nacional de Educação Ambiental e dá outras providências. Diário Oficial [da República Federativa do Brasil], Brasília, DF, n. 79, 28 abril 1999, (Publicação Original). Seção I.

CARVAlHO, I. M. A formação do sujeito ecológico. 2 ed. São Paulo: Cortez, 2006.

CUBA, M. Educação Ambiental nas Escolas. ECCOM. Taubaté, 2010.

FERREIRA, L. F. Proposta de abordagem para a sensibilização ambiental: estudo de caso no centro educacional Polivalente. Monografia. Orientador: Ildeu Soares Martins. Co-Orientadora: Juliana Martins de Mesquita Matos. Universidade de Brasília. Brasília-DF, 2009.

GUIMARÃES, M. A Dimensão Ambiental na Educação. Magistério Formação e Trabalho Pedagógico. Editora Papirus. Brasil, 1995.

GUIMARÃES, M. A Dimensão Ambiental na Educação. $8^{a}$ Edição, Papirus Editora. São Paulo, 2007.

LAYRARGUES, P. P. A resolução de problemas ambientais locais deve ser um tema-gerador ou a atividade-fim da educação Ambiental? In: REIGOTA, M. Verde cotidiano: meio ambiente em discussão. Rio de Janeiro, 1999.

MARTINS, A. P. Avaliação de metodologias de sensibilização ambiental como instrumento para a formação de multiplicadores ambientais no Parque Nacional de Brasília. Dissertação (mestrado) - Universidade de Brasília, Faculdade de Tecnologia, Programa de Pós-Graduação em Ciências Florestais. Brasília, 2013.

MATOS, J. M. M. Métodos e abordagens para a inserção da educação ambiental no currículo escolar. Monografia. Orientadora: Noemi Maria da C. Oliveira. Faculdade Albert Einstein. Brasília-DF, 2015.

MORIN, E. Os Sete Saberes necessários à Educação do Futuro. 2. ed. São Paulo: Cortez, 2000. 
Nossa escola pesquisa sua opinião: manual do professor / editores Ana Lucia D’Império Lima... [et al.]. $3^{\text {a }}$ ed. - São Paulo: Global, 2010.

Sistema Nacional de Unidades de Conservação da Natureza - SNUC: Lei $n^{\underline{0}}$ 9.985, de 18 de julho de 2000; decreto $n^{\circ} 4.340$, de 22 de agosto de 2002. $6^{\circ}$ ed. Aum. Brasília: MMA/SBF, 2006. 56p. 


\title{
CAPÍTULO III: ANÁLISE DOS MÉTODOS DE SENSIBILIZAÇÃO DOS \\ PROGRAMAS DE EDUCAÇÃO AMBIENTAL APLICADOS NO JARDIM BOTÂNICO DE BRASÍLIA
}

\section{Resumo}

O Jardim Botânico de Brasília é parte da Estação Ecológica Jardim Botânico, sendo uma área aberta à visitação pública e oferecendo, além da proteção e serviços ambientais, um programa de educação ambiental para qualquer faixa etária. $\mathrm{O}$ foco deste capítulo foi trabalhar com um grupo escolar do ensino fundamental, acompanhando o desenvolvimento das atividades e o percurso pelo jardim botânico. Além disso, ainda foram aplicados dois questionários estruturados, um para os alunos e outro para a equipe de educação ambiental, procurando identificar qual a relação, orientação perante o ambiente, a consciência das próprias atitudes, as dificuldades enfrentadas entre outras informações úteis para orientação do trabalho com este tipo de público. As crianças demonstraram conhecimento acerca do meio natural, no entanto não apresentaram real compreensão dos recursos que fazem uso. Também foi possível observar o despreparo dos professores que acompanhavam a turma e a competência da equipe.

Palavra-chave: escola, área protegia, trilha.

\begin{abstract}
The Botanic Garden of Brasília, part of the Ecological Station Botanic Garden, is open for public visitation offering protection, environmental services and an environmental education program to any kind of group. The goal of this chapter was to follow na elementary school group along the activity. It was also applied a questionnaire for both, children and workers intending to identify how is the relationship between them and the environment, how aware they are about the resources they use, what are the issues and other informations that helps to deal with this kind of age. the children demonstrated know something about natural environment however did not know for sure the resources they make use. It was also possible to identify how unprepared was the teachers who was leading the group and the capacity of the workers.
\end{abstract}

Keywords: school, protected area, trail. 


\section{INTRODUÇÃO}

O planeta é composto por um sistema dinâmico e auto regulável, resiliente a alterações naturais, no entanto interferências antrópicas tais como desmatamento e uso de químicos são dificilmente acomodados nesse sistema, deixando-o em desequilíbrio. O crescimento populacional pode ser encarado com tal, pois implica em um aumento generalizado de todo tipo de produção, baseado em um sistema político e econômico de consumo exagerado e exploração desmedida dos recursos naturais, quando na realidade o que o homem precisa é ser educado para respeitar o ambiente (MARCONDES e SOARES, 1991).

Segundo Leff (2001) o que acontece é uma visão utilitarista dos recursos naturais, derivada do processo de modernização baseado em um raciocínio econômico. Eis, então, que surge a dúvida: como contribuir para o futuro a partir de pequenas atitudes nos locais em que atuamos? Tudo começa no desafio da mudança de valores e atitudes (PROJETO ESCOLA NO CAMPO, 2005).

Sobre a mudança comportamental, Pedrini e Saito (2014) afirmam existir uma demanda cotidiana por ciência e também que a transição entre um modo de agir e outro será conduzida por uma mudança cultural em uma força tarefa questionadora dos padrões civilizatórios, conceitos e valores sociais, tendo como instrumento mais promissor a educação ambiental (EA).

Esta ferramenta, como afirma o Ministério do Meio Ambiente (2009), é a encarregada pela transição necessária a uma sociedade mais sustentável, onde prevalece o equilíbrio, considerada uma utopia possível. Confere, ainda, à educação ambiental uma ação crítica, transformadora e emancipatória, capaz de preparar indivíduos para o exercício ativo da cidadania em caráter formal e não formal (MMA, 2009).

O caráter não formal da educação ambiental encontra espaço nas unidades de conservação (UC), áreas protegidas com ambientes preservados que acontecem em diferentes categorias, proteção integral e uso sustentável, de acordo com o nível de uso de seu espaço e recursos. O Sistema Nacional de Unidades de Conservação (SNUC) define quais atividades podem ser praticadas em cada uma das doze categorias existentes, que são melhor descritas e detalhadas no plano de manejo de cada unidade.

O Jardim Botânico de Brasília (JBB) é parte da Estação Ecológica Jardim Botânico de Brasília, uma unidade de conservação de proteção integral, cujo objetivo é a 
preservação da natureza e realização de pesquisas científicas, permitindo a visitação pública com finalidade educacional (SNUC, 2006).

Como parte de suas atividades a instituição conta com uma Diretoria de Educação Ambiental (DEA), responsável pelo programa de sensibilização da comunidade escolar, universitária e público em geral quanto à conservação e preservação do meio ambiente e valorização do conhecimento tradicional.

Seguido a linha de raciocínio de Pedrini e Saito (2014), que indagam se é suficiente difundir o conhecimento por meio de publicações científicas e afirmam que esta deve ser produzida para uma dada realidade, ou seja, precisa ser traduzida em prática, este trabalho acompanhou as atividades da equipe de EA não apenas descrevendo-as, mas também identificando qual a interpretação sobre o tema e como se compõe o ambiente natural no raciocínio do público infantil do JBB.

\section{MATERIAIS E MÉTODOS}

\subsection{Caracterização da área de estudo}

O Jardim Botânico é localizado na região sul-central do Distrito Federal (Figura 1), fazendo limites ao:

Norte: IV COMAR (Comando Aéreo) e Lago Sul

Sul: Rodovia DF-01

Leste: Rodovia DF-01

Oeste: APA do Gama Cabeça de Veado

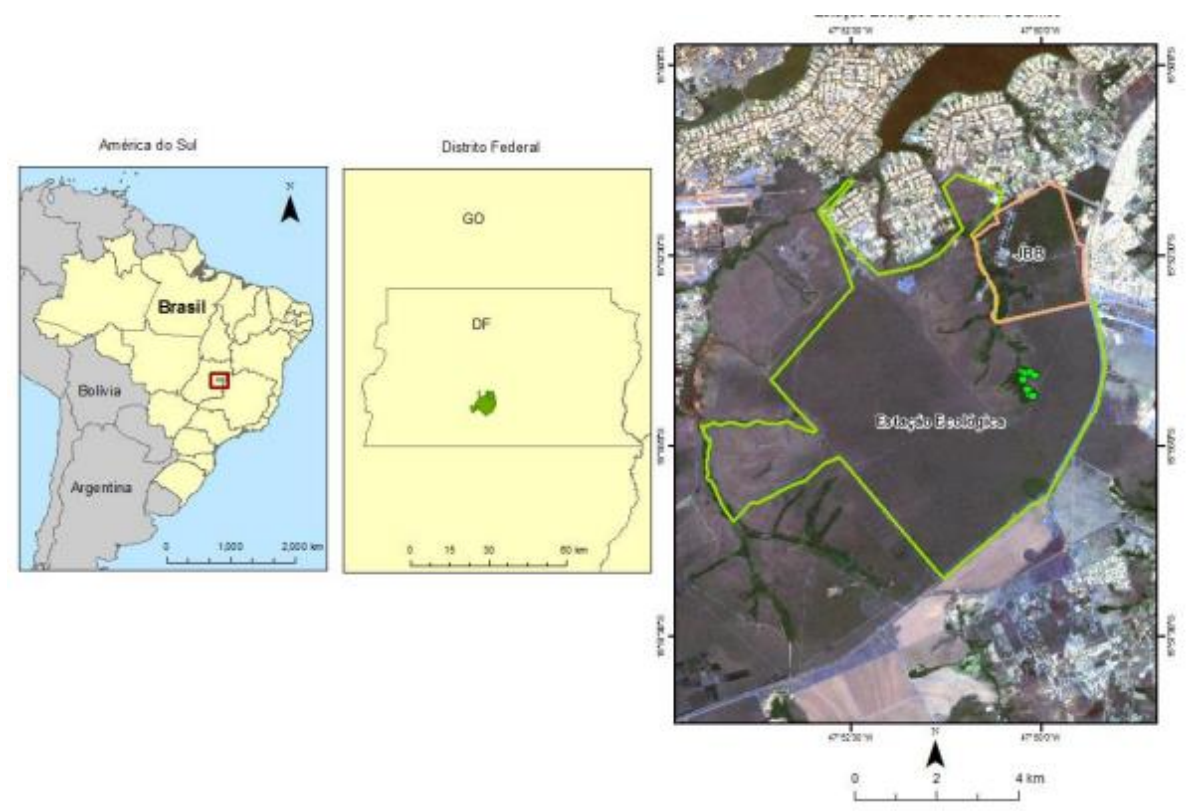

III - Figura 1. Mapa da localização do JBB e ESECJBB no Distrito Federal. Fonte: MENDES, 2013. 
O JBB, somado a Reserva Ecológica do IBGE e a Fazenda Água Limpa (Universidade de Brasília), compõem a Zona de Vida Silvestre da Área de Proteção Ambiental Gama Cabeça de Veado e a Área Núcleo da Reserva da Biosfera do Cerrado.

Inicialmente o JBB foi criado em 1985 com 526 hectares com intuitos de lazer e educação ambiental, sendo até então o primeiro jardim botânico do Cerrado. Sua área foi ampliada para 4.518 hectares com a criação da Estação Ecológica, sob responsabilidade do próprio JBB. No entanto, por ser tratar de uma unidade de proteção integral, apenas os 526 hectares iniciais são abertos à visitação (http://www.jardimbotanico.df.gov.br/).

A sua área abriga recursos hídricos que abastecem $25 \%$ do Lago Sul (bairro de Brasília), além de proteger formações de campo sujo, campo limpo e campo cerrado, vereda, cerrado sentido restrito, mata ciliar e de galeria e cerradão. Quanto à fauna são encontradas espécies ameaçadas de extinção e endêmicas além das outras típicas do Cerrado (http://www.jardimbotanico.df.gov.br/).

\subsection{Caracterização do programa de educação ambiental do JBB}

Baseada na metodologia aplicada por Martins (2013) no Parque Nacional de Brasília, a coleta de dados desta pesquisa consistiu-se em duas etapas: I) acompanhar as atividades desenvolvidas pela equipe de educação ambiental do Jardim Botânico de Brasília e II) aplicação de questionário estruturado para a equipe de educação ambiental e para os alunos participantes do programa.

Os dados obtidos foram analisados e relacionados com dados levantados a partir de dissertações, artigos, publicações diversas e legislação correlata ao tema de estudo deste trabalho.

\subsubsection{Aplicação de questionário}

Os questionários foram elaborados baseados na metodologia de Martins (2013) e Ferreira (2009) com o intuito de caracterizar os alunos que participam da atividade escolar de visita ao JBB e a equipe de trabalho, conhecer suas expectativas, dificuldades, grau de percepção ambiental e, claro, o seu conceito de educação ambiental.

\subsubsection{Alunos}

Para o trabalho com os alunos que visitam o Jardim Botânico participando do programa de educação ambiental foram elaboradas onze perguntas com o intuito de 
nortear-se quanto a percepção ambiental das crianças. Buscou-se avaliar como se dá a percepção do ambiente da UC em que estão, a utilização dos recursos naturais, práticas de conservação e da própria educação ambiental entre outros pontos.

O questionário foi aplicado apenas uma vez, antes da realização do percurso, justamente para evitar qualquer tipo de influência do conteúdo apresentado e se obter a impressão bruta dos alunos quanto à temática ambiental, apesar da mesma já ser discutida na escola.

Por se tratar de um questionário estruturado as perguntas eram de múltipla escolha, sendo possível, na maioria delas, a escolha de mais de uma opção de resposta, tendo sido respondido ao todo 24 questionários por crianças entre 8 e 9 anos.

\subsubsection{Equipe de educação ambiental}

Para identificar o perfil da equipe responsável pelo Programa foram desenvolvidas quatro perguntas referentes à formação de cada integrante, o tempo de trabalho dentro da unidade de conservação, qual a atuação dentro do Programa e quanto ao treinamento para ministrar as atividades.

\section{RESULTADOS E DISCUSSÃO}

\subsection{Descrição do programa de educação ambiental}

O Jardim Botânico de Brasília recebe grupos de todas as idades para a atividade de educação ambiental. No entanto, para fins desta pesquisa, limitou-se a análise aos grupos escolares, ou seja, o público infantil.

Observou-se que o grupo é encaminhado para uma estrutura chamada ninho do pássaro, onde as crianças são dispostas em roda para ser feita a apresentação da equipe e são conduzidas em um exercício de corporeidade para ativar o corpo e os sentidos com exercício de automassagem, respiração e alongamento. Em seguida são apresentadas algumas informações sobre o Jardim Botânico, como por exemplo os seus objetivos: preservar, pesquisar e educar; que se trata de uma unidade de conservação e apenas uma parte de sua área é aberta à visitação enquanto a outro é fechada com o propósito de conservação, a produção da água que abastece o Lago Sul (bairro de Brasília-DF) e o tamanho de sua área. 


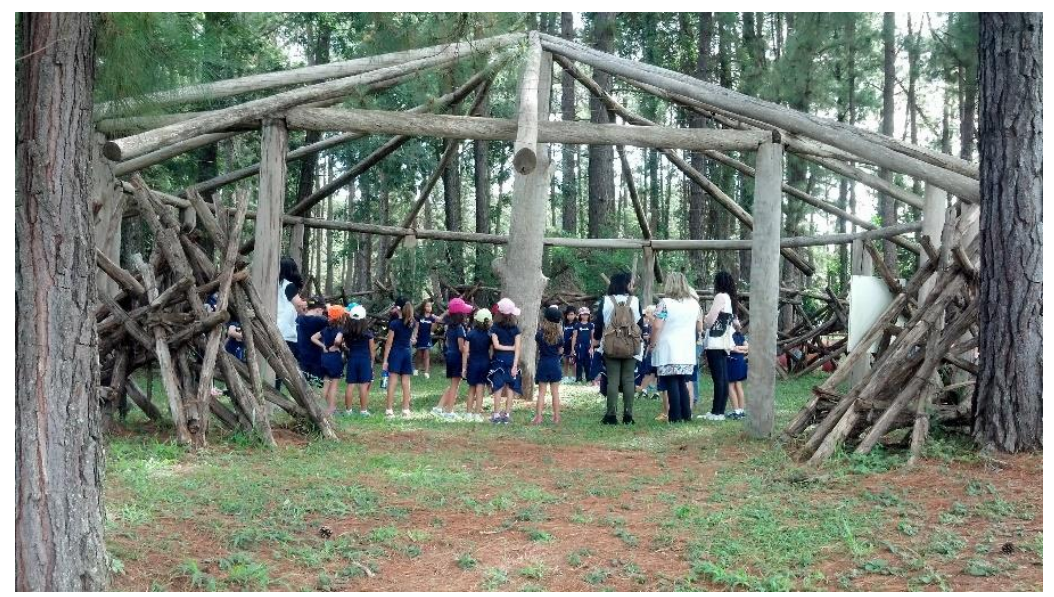

III - Figura 2. Automassagem no ninho do pássaro do Jardim Botânico de Brasília. Fonte: Arquivo pessoal da autora.

Também foi esclarecida a presença das espécies exóticas que se encontram no local, devido ao surgimento do JBB como Fundação Zoobotânica, cuja finalidade era a experimentação.

O conteúdo ambiental começa com a exposição quanto a relação de dependência entre o homem e o ambiente e o fato de tudo ter o seu papel na natureza, não existindo nada sem alguma função ou importância.

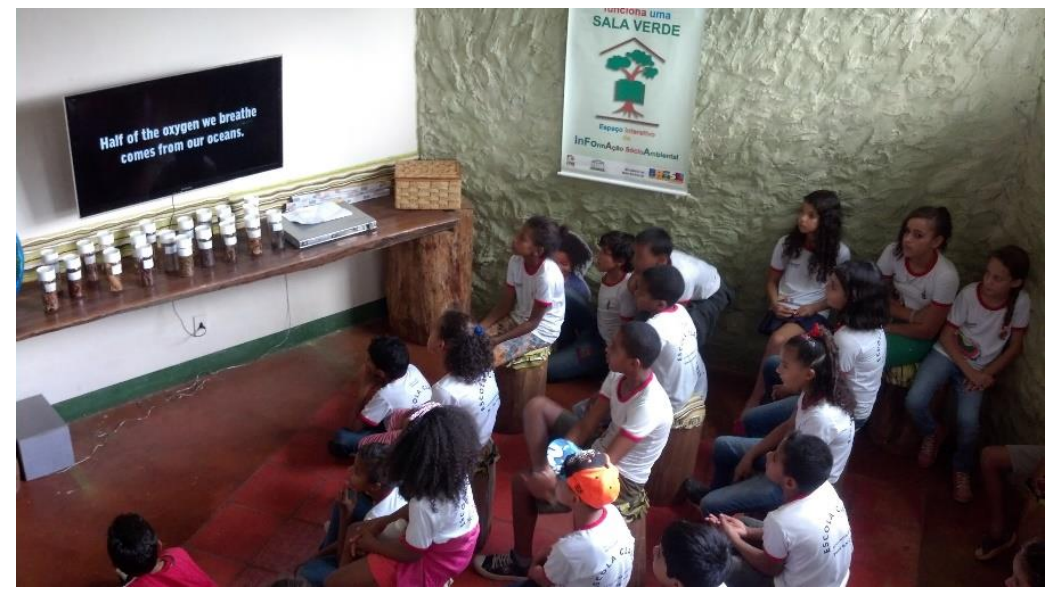

III - Figura 3. Apresentação de vídeo informativo no Jardim Botânico de Brasília. Fonte: Arquivo pessoal da autora.

Ao longo da caminhada pela unidade foram sendo apresentadas algumas espécies com suas curiosidades, enfatizando que o Cerrado é um dos biomas mais ricos e ameaçados do mundo, que provê alimentos durante todo o ano, sendo também muito ornamental.

Na casa das bromélias foram mostradas as variações de tipos, cores e tamanhos, ressaltando a sua função ecológica como microambiente e sua importância para as espécies pequenas que, por isso, não se pode tirar as plantas do seu ambiente, desencorajando qualquer distúrbio na natureza. 
Passa-se pelo jardim de cheiros, onde são apresentados algumas ervas de uso comum e sentidos os cheiros e texturas. Já na estufa de cactos e suculentas foi demonstrada a diferença entre os tipos de plantas e a adaptação ao clima desértico.

Chegando ao centro de visitantes é visualizado um mapa com o trajeto, segue-se para o relógio do sol, explicando o seu funcionamento e a variação de acordo com as estações do ano. Em seguida percorre-se o jardim evolutivo, formado em espiral de forma que as espécies mais primitivas encontram-se no centro e as mais evoluídas (com flores e frutos), nas bordas, sendo feita toda a contextualização do ambiente e as vantagens que a evolução conferiu às espécies vegetais, salientando a relação fundamental com os polinizadores, dispersores e a coevolução entre plantas e animais, demonstrando como tudo está interligado e os benefícios que mesmo os menores seres prestam ao ecossistema.

Saindo do orquidário as crianças são conduzidas pela Alameda Cerrado, onde são apresentadas espécies típicas deste bioma, como o jatobá (Hymenaea stigonocarpa) e o barbatimão (Stryphnodendron adstringens), com suas propriedades medicinais.

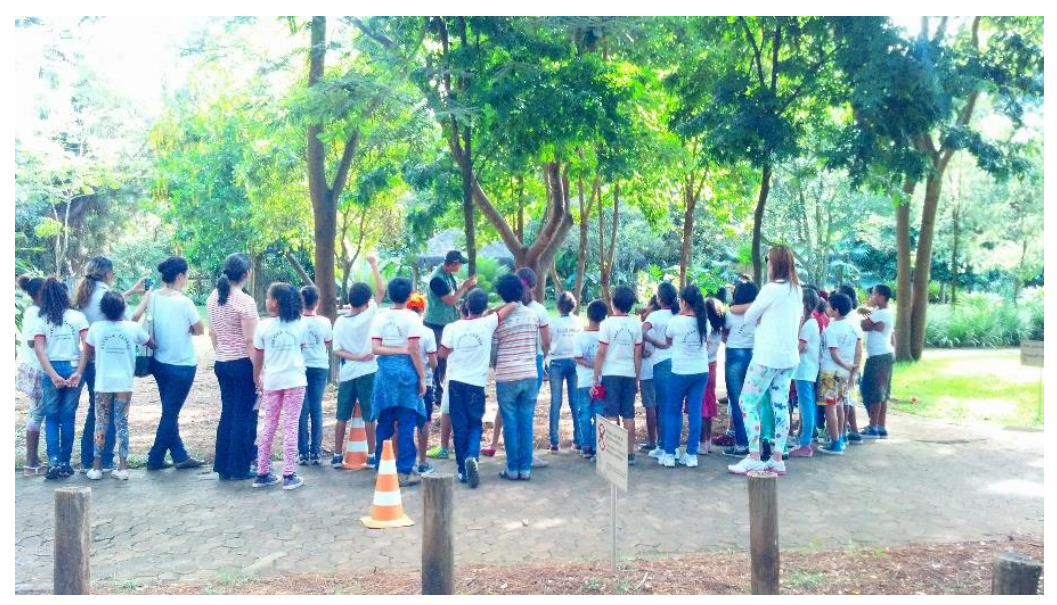

III - Figura 4. Caminhada pela área do Jardim Botânico de Brasília. Fonte: Arquivo pessoal da autora.

Finalizando a atividade foi feito um lanche (trazido pelas próprias crianças) e uma avaliação, perguntando-se a parte preferida do passeio, relembrando os objetivos do Jardim Botânico e pedindo-se para que cada um seja defensor da natureza, desta unidade de conservação e do Cerrado.

De uma forma geral as crianças ficam naturalmente dispersas, demonstrando interesse em encontrar algum animal (apesar de se tratar de um jardim botânico) e apresentando maior interesse pelo encontro casual com qualquer tipo de fauna, como pássaros, peixes ou aranhas, comuns na área. 
As próprias professoras que acompanhavam a turma pareciam estar passeando, conhecendo o local, de fato uma delas nunca havia estado no JBB e, além de não fazerem nenhuma pergunta e/ou direcionarem os alunos a qualquer questionamento, ainda queriam levar mudas ou partes de plantas. Este comportamento evidencia a necessidade de um preparo prévio destes educadores para acompanharem seus alunos. É preciso conhecer o local previamente e ter objetivos definidos antes da visita para melhor aproveitar a experiência e dar continuidade no processo de aprendizagem ambiental.

Segundo Weiler e Ham (citados por WEAVER, 2001), a interpretação ambiental deve se pautar em quatro componentes: ser agradável, pertinente, organizada e girar em torno de um tema. Portanto, a forma mais fácil de fazer com que o visitante absorva os conceitos é transmiti-los de forma lúdica. Assim fica destacado o papel do professor nesse contexto, visto que a estratégia de transmissão do conhecimento deve estar baseada no planejamento das atividades. Ainda que a educação ambiental tenha sido realizada na UC, cabe ao professor provocar em sala uma reflexão da vivência para estimular a formação dos valores e a construção do cidadão. Há que se considerar que o aluno envolvido por esse trabalho passa a ser também um multiplicador dessas ideias, já que é um agente social que está integrado ao círculo de convivência e, consequentemente, fará a propagação do conhecimento junto aos seus familiares e amigos.

\subsection{Análise dos questionários}

\subsubsection{Alunos}

Os questionários foram respondidos por uma das turmas de alunos que agendou uma visita para participar do programa de educação ambiental do Jardim Botânico de Brasília.

Esta primeira pergunta pretendeu identificar qual a imagem do Jardim Botânico para as crianças (Figura 5). As respostas a esta pergunta revelam uma percepção interessante, talvez por estarem cumprindo uma atividade escolar a grande maioria (75\%) tenha identificado a sua vertente educacional, seguida pela visitação pública $(29,2 \%)$, proteção da natureza $(16,7 \%)$ e finalmente lazer $(4,2 \%)$. 


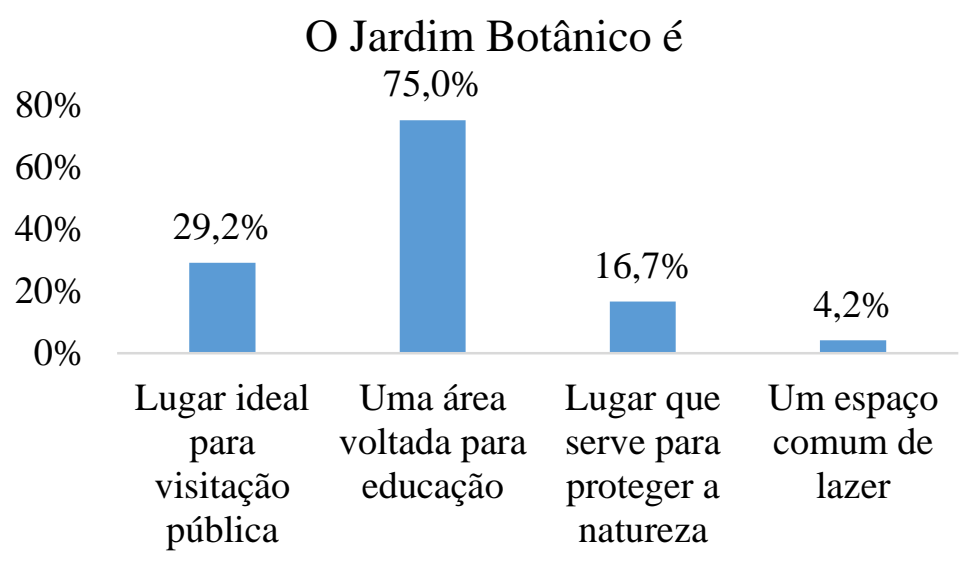

III - Figura 5. Respostas a primeira questão: "Para você o JBB é".

Menos da metade dos estudantes identificam o JBB como um espaço de visitação, de forma que, no entendimento deste grupo a finalidade principal é a educação, quando na realidade este é mais um de seus propósitos, principalmente considerando o fato de se tratar de uma unidade de conservação. No entanto é possível afirmar que escapa da consciência dos estudantes a real dimensão e objetivos do Jardim Botânico, o que reforça a necessidade de um trabalho de educação.

Importante ressaltar que apesar de se tratar de uma unidade de conservação de proteção integral, a categoria mais restritiva, a parte aberta à visitação prevê os tipos de atividade citadas desde que orientadas e não representando riscos à conservação da biodiversidade.

Ainda com o mesmo raciocínio da questão anterior, a próxima pergunta objetivou identificar se há compreensão das razões da existência do JBB (Figura 6).

\section{O JBB existe porque}

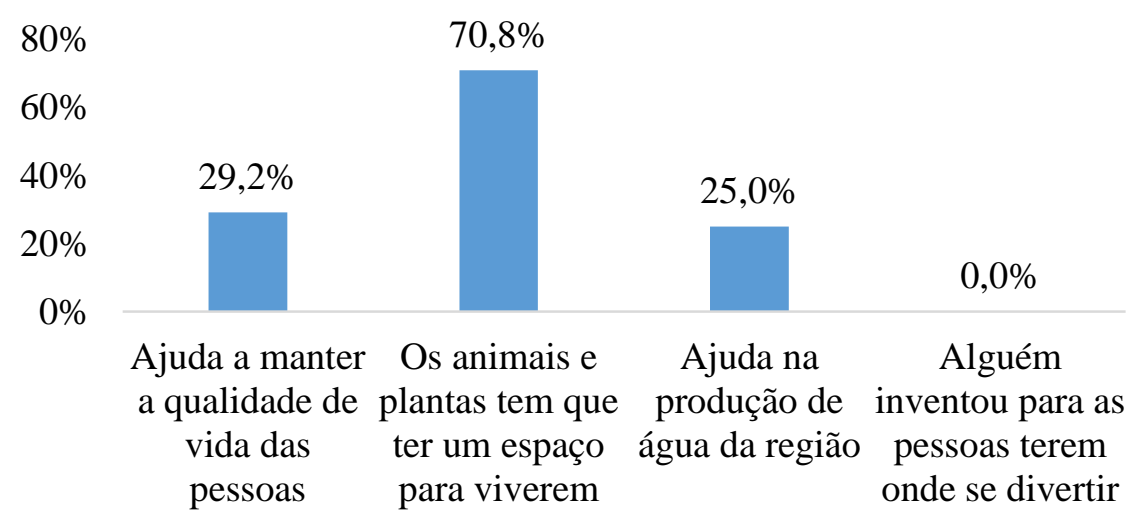

Figura 6. Respostas a segunda questão: "O JBB existe por que?".

III - Curiosamente o mesmo grupo de estudantes que quase não identificou o espaço como sendo um local para a proteção da natureza agora tem a grande maioria de 
17 alunos apontando como sendo a morada de animais e plantas, indicando uma lacuna na percepção desses conceitos. O entendimento de que não se trata de um ambiente de diversão e a relação com a qualidade de vida das pessoas e produção de água é muito positiva, se fazendo novamente necessário o esclarecimento quanto aos objetivos do JBB, e de que forma está relacionado com a qualidade de vida das pessoas e os serviços ambientais que são fornecidos.

Há claramente uma divisão no entendimento das crianças quanto ao espaço natural e o espaço humano, como se este fosse beneficiado indiretamente e não fazendo uso de forma ativa de tudo o que é oferecido.

O percentual próximo entre o segundo $(29,2 \%)$ e o terceiro $(25 \%)$ itens pode indicar que foram relacionados, de forma que a produção de água gera a qualidade de vida das pessoas. Este é um raciocínio que se pretende desenvolver, no entanto deve-se expandir os horizontes e englobar o maior número possível de benefícios e serviços ambientais que são fornecidos por essa área, afim de que seja entendida a sua real dimensão, missão e uso.

Quanto à divisão de espaços na compreensão das crianças, é importante ressaltar que ela existe por uma imposição do homem, animal mais recente a surgir e que, para se estabelecer limitou a existência de plantas e animais. Outro ponto a ser destacado é a questão dos serviços ambientais prestados, como por exemplo a produção de água que abastece o lago Sul, que influenciaram diretamente na criação desta área, não sendo uma consequência.

A terceira questão (Figura 7) trata das finalidades do espaço, de forma que a grande maioria dos estudantes identificam o JBB como um local de contato com a natureza, demonstrado por um total de 19 crianças. No entanto esta não é uma atividade associada ao lazer, ideia que pode ser corroborada pelo segundo maior percentual da questão, aprender conteúdos escolares (7 crianças), pode-se dizer que é um percentual baixo considerando se tratar de uma atividade escolar. Quanto as outras opções pode-se dizer que não são significativas. 


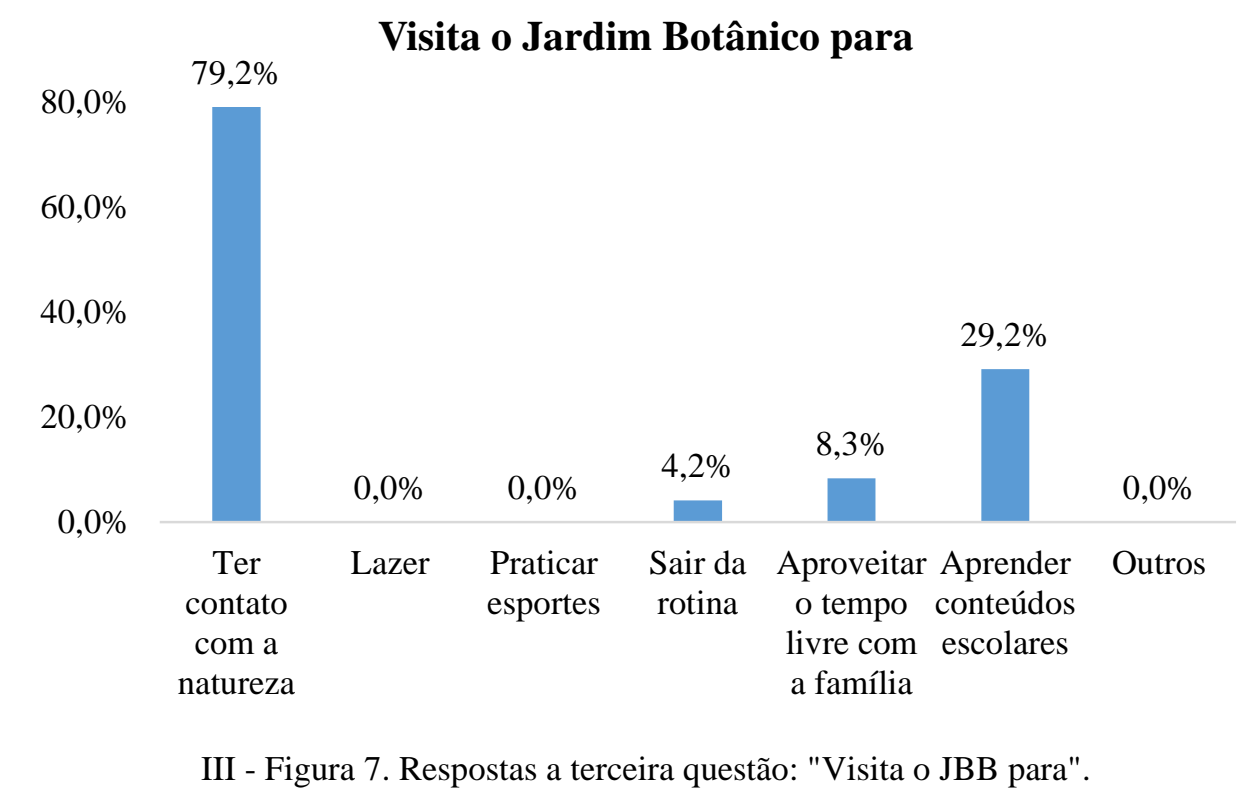

As respostas indicam não haver uma compreensão totalmente correta do funcionamento da unidade, se fazendo essencial este esclarecimento, que é justamente contemplado na proposta do seu programa de educação ambiental, possibilitando um melhor aproveitamento por parte dos visitantes.

A Figura 8, referente a quarta pergunta, trata sobre a percepção deste público quanto a fauna.

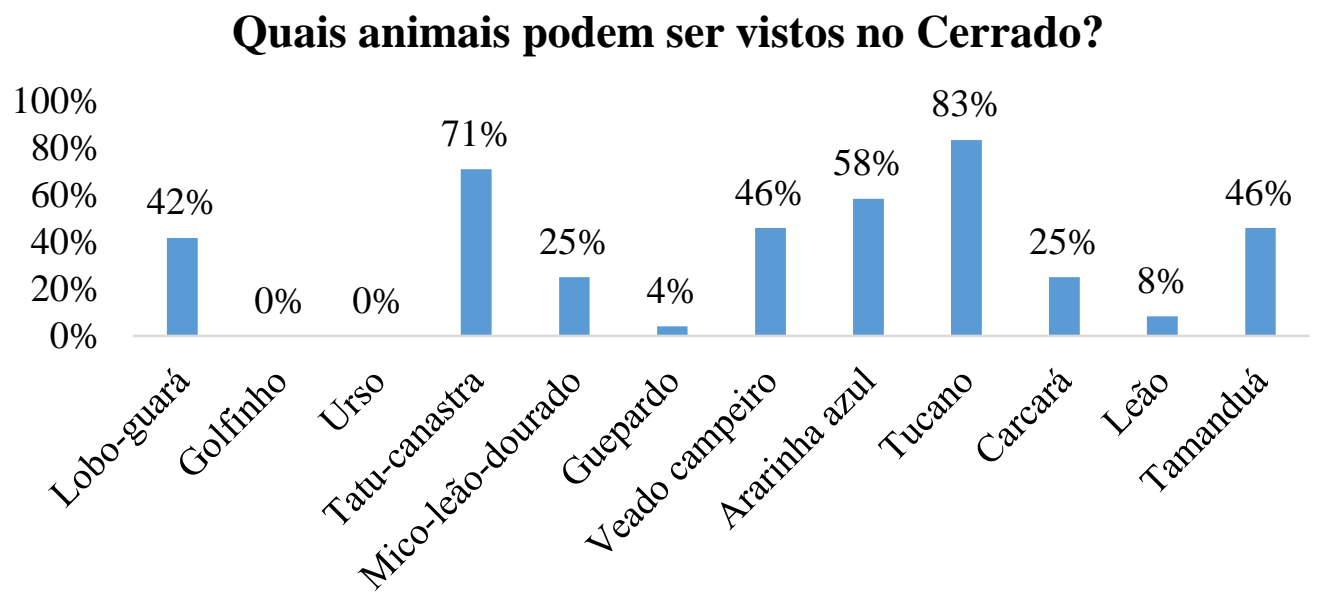

III - Figura 8. Respostas a quarta questão: "Quais animais podem ser vistos no Cerrado?".

Apesar de se tratar de um jardim botânico, local destinado a plantas, durante todo o percurso os estudantes mostraram interesse em encontrar animais, principalmente os de grande porte e houve grande dispersão ao se depararem com qualquer tipo de fauna, aranha, pássaros, lagartos, que são comuns em locais como este.

Os questionários foram respondidos de forma muito consciente quanto a fauna típica do Cerrado, não sendo apontados de forma majoritária nenhum animal que não 
pertença a este bioma. Esperava-se um reconhecimento maior para o lobo-guará, espécie bandeira e símbolo deste bioma central, no entanto esta falta de reconhecimento demonstra real conhecimento dos animais nativos, e não apenas o reconhecimento de campanhas de conservação.

Apesar de tudo alguns animais exógenos apresentaram certo percentual, como é o caso da ararinha azul e outros como o guepardo, leão e mico-leão-dourado, indicando que são animais familiares, podendo ser avistados em zoológicos, por exemplo, mas que no entanto não se tem conhecimento quanto ao habitat natural dos mesmos. Cabe ainda uma discussão quanto às táticas de conservação destes animais, todos estão ameaçados, e baseado no exposto anteriormente, foca-se no animal sem se preocupar com seu ambiente, quando o alvo de conservação deveria contemplar também o nicho, ou seja, os recursos necessários à sua sobrevivência, agindo de forma completa.

Seguindo a mesma linha a quinta questão, Figura 9, busca a percepção quanto as frutas:

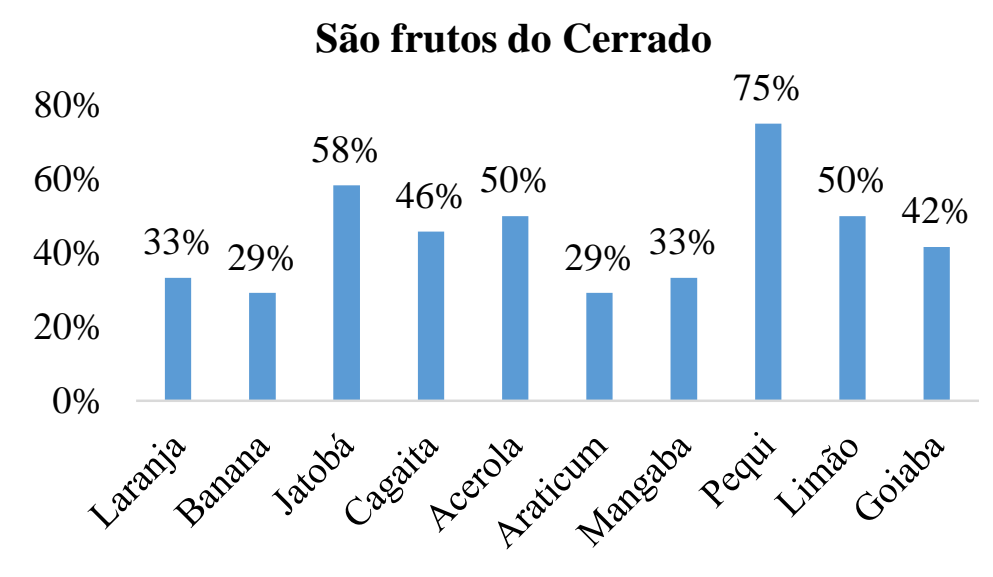

III - Figura 9. Respostas a quinta questão: "São frutos do Cerrado".

A percepção se mostrou mais confusa. Estas são conhecidas, no entanto as frutas que são usualmente consumidas e encontradas facilmente em mercados são associadas ao Cerrado por estarem presentes no cotidiano das crianças e, sendo o Cerrado o bioma em que estão inseridas, associam as frutas a ele.

Estes percentuais retomam a discussão quanto ao conhecimento do fruto mas não da sua origem, o que poderia ser trabalhado em uma campanha de conservação e valorização dos recursos naturais do Cerrado, pois não se pode esperar que as pessoas façam uso e valorizem aquilo que não conhecem, dando a oportunidade que se adote o que vem de fora, por se ter um marketing melhor, desprezando o que faz parte da sua cultura. 
O próximo gráfico, Figura 10, apresenta alternativas sobre como proteger a natureza, sendo discutida quais delas foram melhor assimiladas pelos estudantes.

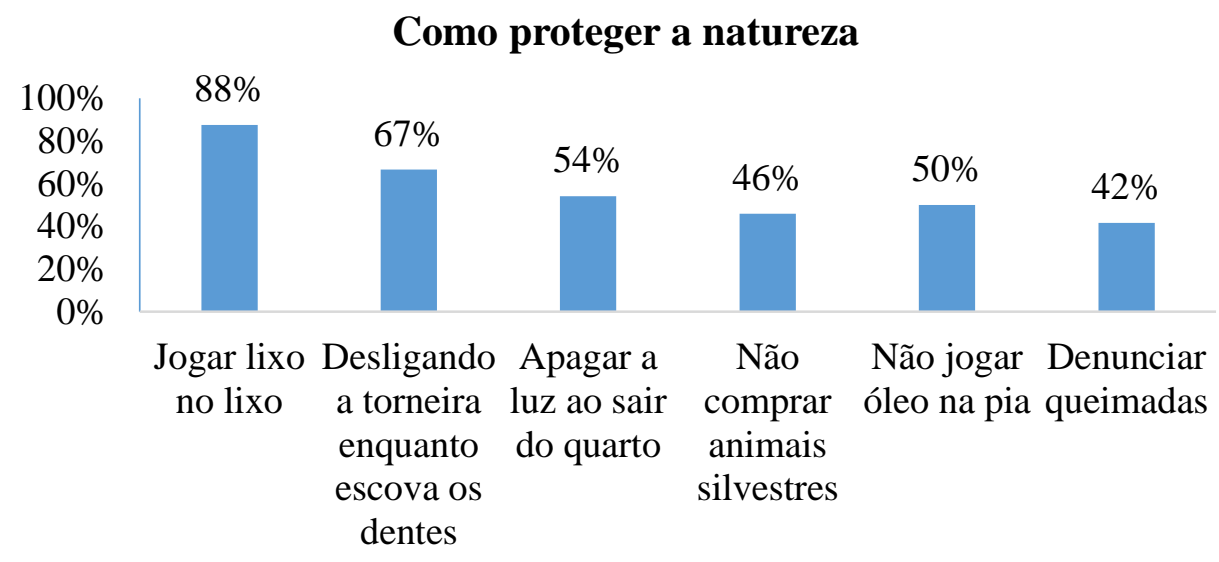

III - Figura 10. Respostas a sexta questão: "Como proteger a natureza?".

Todas as opções desta pergunta poderiam ser assinaladas corretamente, sendo assim a intenção é identificar quais formas de proteção ao ambiente compõem o consciente das crianças. O que elas identificam como atividades ambientalmente corretas, servindo de base para o trabalho de educação ambiental (o que deve ser reforçado, acrescentado e melhor trabalhado), cujo principal objetivo é alcançar a mudança de comportamento por meio do esclarecimento, sensibilização e raciocínio crítico.

A alternativa mais escolhida, $88 \%$, foi jogar lixo no lixo, um jargão educacional que é aplicado tanto ao meio natural quanto no urbano. Desligar a torneira ao escovar os dentes $(67 \%)$ e apagar a luz (54\%) também são atitudes que vem sendo incentivadas e incorporadas nos hábitos do dia-a-dia, principalmente em tempos de crise ambiental.

As três últimas alternativas já são de mais difícil compreensão para a faixa etária dos alunos, apesar dos percentuais terem sido mais elevados do que o esperado, indicando uma consciência ambiental madura. No entanto ainda se trata de menos da metade dos respondentes, consistindo em temas a serem melhor trabalhados, pois implicam em uma compreensão sistêmica de como estas atitudes afetam a fauna e a flora, o que ainda é difícil de se conseguir se tratando de um público infantil.

Quanto a próxima pergunta, Figura 11, as suas opções intencionaram identificar como acontece a relação das crianças com o ambiente natural: se é apenas de contemplação (são bonitas), se não se compreendem pertencentes a ele (morada dos animais), se fazem uso dele (remédios), lazer (trilhas), ou se compreendem a relação de dependência para manutenção da vida (controle climático). 


\section{Por que é importante conservar as florestas?}

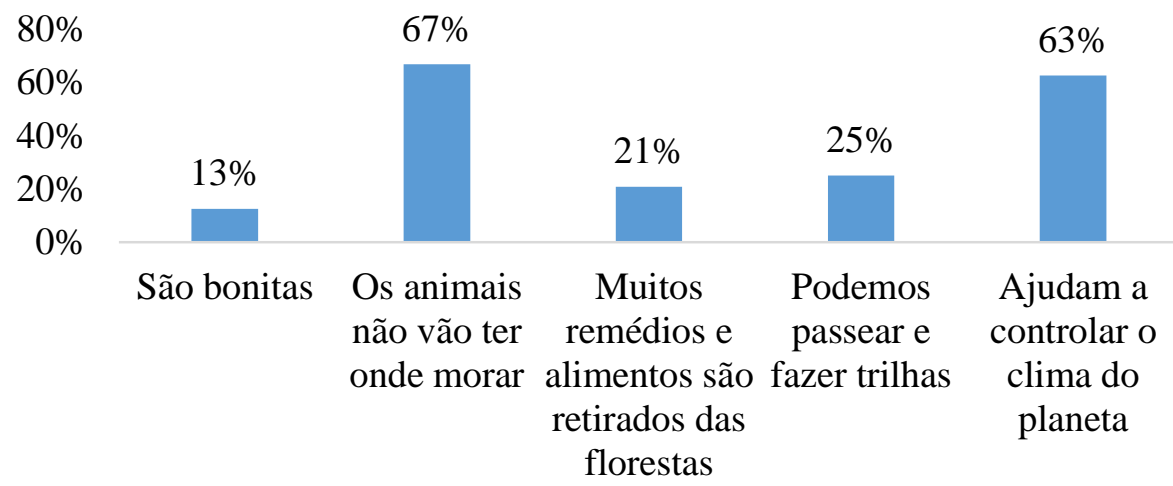

III - Figura 11. Respostas a sétima questão do questionário: "Por que é importante conservar as florestas?".

Como já comentando anteriormente, a composição do ambiente acontece separando-se o espaço urbano do natural, de forma desconectada, sendo assim a maioria dos estudantes (67\%) apontou esse distanciamento indicando que as florestas devem ser preservadas devido a fauna, pois este é o seu lugar, como indicado na segunda questão. Quase o mesmo percentual (63\%) indicou conhecer a importância das florestas para o controle do clima, o que não é surpreendente, afinal com as atuais preocupações e discussões quanto ao aquecimento global e temas correlatos este é um tópico que passou a compor o cotidiano das pessoas, mesmo que de forma superficial.

A relação de uso (21\%) foi pouco assinalada, podendo-se assumir não estar consolidado o conhecimento de onde é retirada a matéria prima para fabricação de remédios, e tampouco o conhecimento das propriedades medicinais das ervas e árvores do Cerrado, riquíssimo também neste quesito.

Quanto ao lazer (25\%), entende-se não ser feito uso de espaços naturais para este tipo de atividade, indicando a necessidade da sua incorporação no mundo das crianças (a ser repassado para os pais), para que passe a ser uma opção e se dê início ao processo de assumir o pertencimento àquele local.

Esta pergunta seguinte (Figura 12) é fundamental neste estudo, pois implica em identificar qual a compreensão dos participantes em relação ao trabalho que estão participando e se entendem o que estão fazendo. 


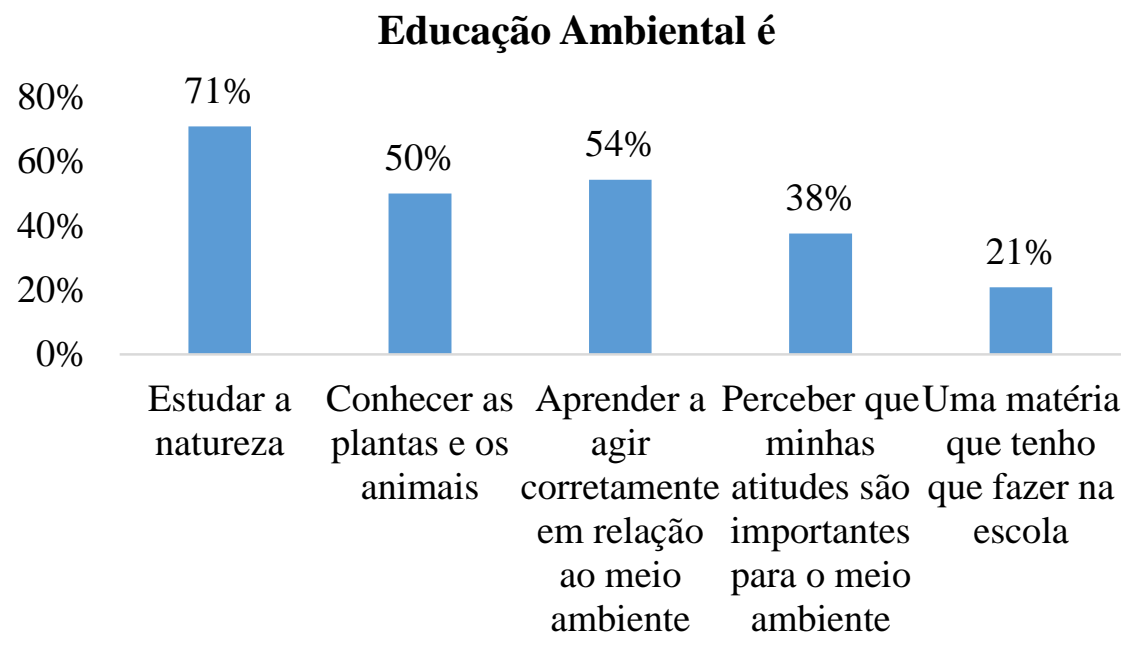

III - Figura 12. Respostas a oitava questão: "Educação ambiental é".

Neste caso, $71 \%$ dos estudantes entende inicialmente que a educação ambiental como sendo simplesmente estudar a natureza, o que remonta ao seu conceito antigo, que considerava apenas as interações ecológicas, no entanto este conceito foi sendo modificado até a sua versão mais atual, que considera e trabalha o contexto socioambiental, no entanto é importante ressaltar que o conhecimento na natureza é fundamental, retomando a ideia de que apenas de preserva o que se conhece, sendo assim a ecologia passou a ser um dos temas trabalhados, não mais o único.

Curiosamente conhecer plantas e animais, ideia complementar ao primeiro item, obteve um percentual muito discrepante deste (50\%), esperava-se que ambos fossem assinalados de forma similar. Isso demonstra que não existe uma linha de raciocínio formada, os temas não são relacionados entre si, o que pode derivar da prática fragmentada de se trabalhar o conhecimento, o que facilita a compreensão das partes, mas que no entanto não gera resultados significativos se não for aplicado na prática em um contexto holístico, forma de trabalho da educação ambiental.

Em segundo lugar (54\%) foi indicado que EA é apender a agir corretamente em relação ao meio ambiente, o que está compreendido no processo, mas que indica certa passividade de receber este conteúdo, enquanto que perceber, quarto item, implica em ação, reconhecimento. A importância na diferença entre esses dois conceitos consiste no fato de que o primeiro gera o conhecimento e não necessariamente a ação, enquanto que o segundo leva a uma análise comportamental e o entendimento da necessidade da mudança de certos hábitos, tornando o indivíduo agente de sua própria mudança, acreditando-se inclusive na longevidade dessa mudança. 
Quando se trata de recursos naturais se torna difícil comparar a importância, ou melhor, intensidade de uso, de um em relação ao outro, mesmo em se tratando de petróleo, afinal hoje a população mundial se tornou quase tão dependente quanto o ar que respiram (Figura 13).

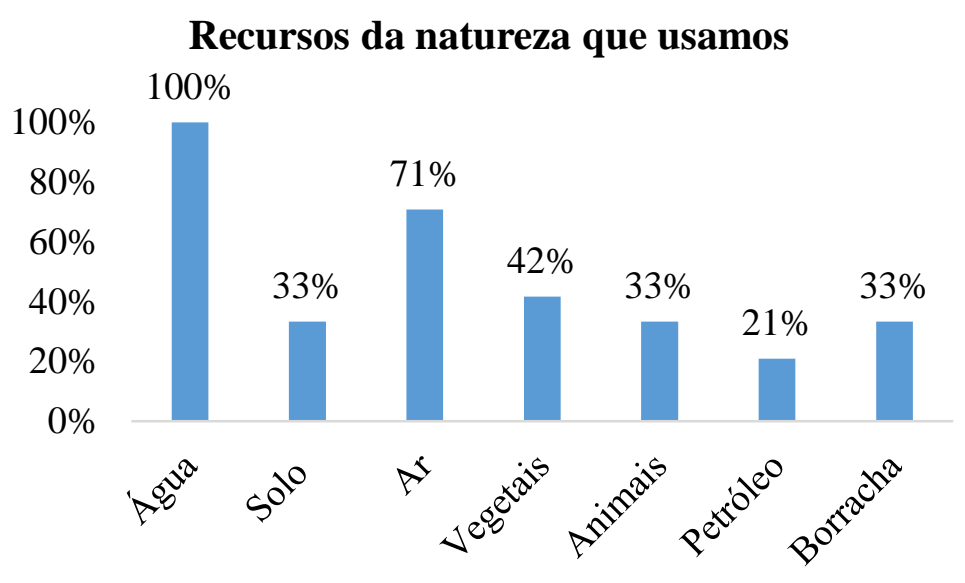

III - Figura 13. Respostas a nona questão do questionário: "São recursos da natureza que usamos".

A intenção desta pergunta não consiste em comparação e sim identificar quais dos recursos citados são mais reconhecidos pelas crianças, o que indica quais são mais representativos no contexto de cada um. Naturalmente a água foi o recurso mais assinalado, por absolutamente todos os estudantes, seguido pelo ar, com $71 \%$.

Em relação aos outros itens não houve um consenso tão grande, o que surpreende no caso dos vegetais (42\%), solo (33\%) e animais (33\%), que são elementos extremamente presentes no dia-a-dia de qualquer pessoa. Para este estudo são dados muito relevantes, pois demonstram quão importante se faz um trabalho de educação ambiental para que haja a percepção do uso que fazemos dos recursos disponíveis de forma tão presente que passam a não serem notados, apenas quando deixam de existir, diga-se de passagem.

Quanto a borracha (33\%) e o petróleo (21\%) já era esperado um percentual menor. Considerando não se fazer uso direto destes recursos e sim de derivados, seria necessário o conhecimento do processo produtivo dos mesmos, o que não se espera deste tipo de público. No entanto este é um tema que deve ser trabalhado para que seja construída essa compreensão do sistema de exploração e uso de recursos naturais para que se desenvolva um uso consciente, atingindo um dos principais objetivos da EA.

O estudo realizado por Ferreira (2009), aplicando um questionário semelhante com o objetivo de avaliar a ação do trabalho de educação ambiental, ao perguntar quais produtos tinham sua matéria prima extraída da natureza constatou que a borracha e a 
gasolina, assumindo o papel do petróleo, foram assinalados por $81 \%$ e $51 \%$, respectivamente, dos alunos. Diferentemente deste trabalho, o seu questionário foi aplicado após o conteúdo, o que indica, ao menos neste quesito, o cumprimento do objetivo do programa de EA da escola quanto a percepção do uso destes recursos.

Aqui é interessante relembrar a questão da interdisciplinaridade da EA, que rompe com a fragmentação imposta pelo sistema tradicional de aprendizagem, como é discutido por Morin (2000), que coloca a segmentação como um problema por não considerar o contexto do objeto de estudo, criando especialistas nas partes e medíocres no todo, ou ainda conforme afirma Araujo (2014) ao lembrar que o existir humano não é fragmentado.

Sendo assim, a importância do caráter interdisciplinar da EA é igualar-se à vida, complexa e inter-relacionada, trabalhando fatos e não teorias (GUIMARÃES, 2007).

Passando para a décima pergunta do questionário (Figura 14), que trata do uso do Jardim Botânico de Brasília tem-se quem:

Já conhecia o Jadim Botânico?

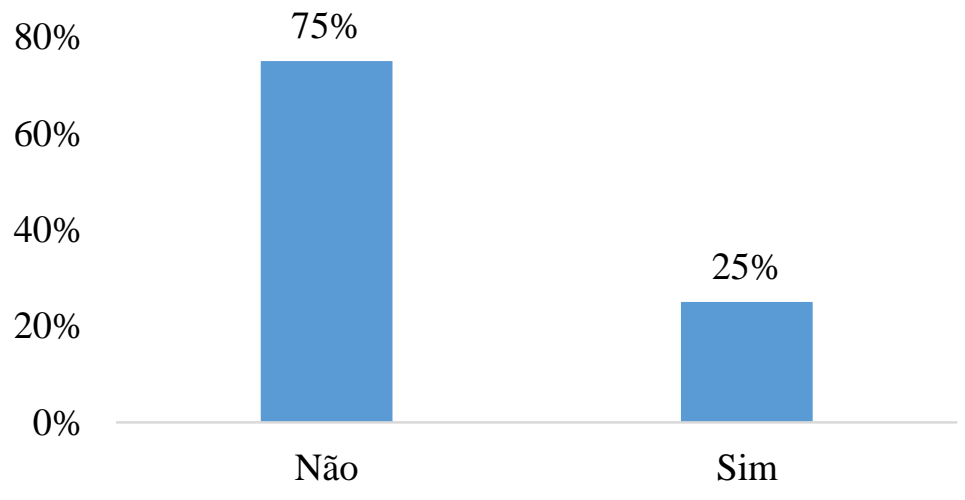

III - Figura 14. Respostas a décima questão: "Já conhecia o JBB?".

Apesar de ser um local aberto ao público e de entrada acessível a grande maioria das crianças $(75 \%)$ disseram não conhecer o Jardim Botânico antes dessa atividade, o que é um fator preocupante, indicando que as pessoas não fazem uso deste espaço, não fazendo uso não conhecem, não conhecendo não valorizam, não valorizando não cuidam.

Possivelmente não é apenas o JBB que não costuma ser frequentado por este e por outro tipo de público pode-se assumir, outras áreas verdes, unidades de conservação também podem não estar sendo consideradas como áreas de uso tanto para lazer quanto para estudo. 
Na última questão, Figura 15, optou-se por não restringir a pergunta a unidades de conservação, pois pode ser difícil para as crianças diferenciarem uma área verde de unidade de conservação, visto suas diferentes categorias e usos. O número de crianças (11) que disseram já ter visitado algum parque foi menor do que o número de crianças que já visitou algum (13).

\section{Já visitou outra UC/parque?}

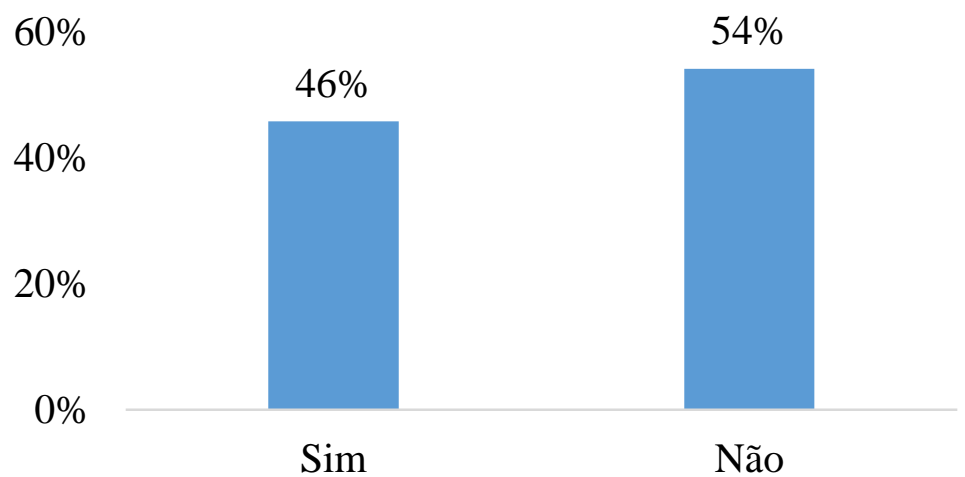

III - Figura 15. Respostas a décima questão do questionário: "Já visitou outra UC/parque?".

Da mesma forma que a questão anterior, verifica-se que as crianças não costumam frequentar parques e unidades de conservação, o que faz com que se pergunte se a população em geral também não faz uso dessas áreas.

Além da missão de conservar os recursos naturais as unidades de conservação, cada uma com seus objetivos e restrições, tem também compromisso com a população, seja oferecendo uma opção de lazer, seja despertando cidadãos emancipados e conscientes por meio da educação ambiental. Mas para que funcione é preciso não apenas que a população frequente as UC's, mas também que conheçam seus propósitos, objetivos e funcionamento, evitando conflitos (principalmente com a comunidade vizinha) e se apossando de uma área pertencente a cada indivíduo. Esta deveria ser uma questão de extremo interesse governamental que ganharia agentes multiplicadores, facilitando a gestão destes locais.

\subsubsection{Dados extraídos a partir do questionário estruturado aplicado à equipe de educação ambiental}

A equipe de educação ambiental é composta por cinco membros com formação acadêmica na área ambiental e na área de música. 
Apesar de haver uma divisão de tarefas para suprir as demandas do programa todos os membros realizam o atendimento aos grupos na dinâmica de revezamento e, sempre que possível, com mais de um responsável.

É um grupo de trabalho novo. O treinamento acontece na área do próprio Jardim Botânico de forma que os funcionários mais antigos instruem os mais novos no percurso das trilhas e como são realizadas as atividades com os membros mais antigos e também por meio da participação em cursos e reciclagens, seminários e congressos.

Quanto a educação ambiental foi colocado ser a construção de valores sociais, habilidades, atitudes e conhecimento voltados para a relação com o ambiente por meio da troca de experiências entre educando e educadores, reinserindo o homem no ambiente natural. Que é um processo lento e contínuo no sentido de mudança comportamental a partir da compreensão da importância do ambiente preservado, corrigindo as distorções na relação homem/recursos naturais, visando um meio ambiente equilibrado, garantindo o direito de todos como previsto no Artigo 255 da Constituição Federal.

\section{CONCLUSÃO}

O trabalho de educação ambiental desenvolvido pela equipe do Jardim Botânico de Brasília busca promover a sensibilização ambiental seguindo a linha de indução ao pensamento crítico quanto a responsabilidade individual para a preservação do meio ambiente, principalmente o Cerrado.

O reconhecimento do uso dos recursos naturais pode passar despercebido por já estarem tão arraigados no cotidiano; é fundamental saber de onde vem a matéria prima usada e o impacto deixado no ambiente.

Valorizar este conhecimento é valorizar a cultura, despertando o orgulho de pertencer a este local, gerando o sentimento de pertencimento necessário para que se deseje cuidar de algo.

Pode-se reparar que o público infantil participante não demonstrou real conhecimento à cerca do Jardim Botânico, apesar deste ser aberto à visitação, demonstrando a não utilização deste espaço, seja pelas escolas, seja para lazer.

Apesar de não ter sido apontado nenhum conflito manejado pela educação ambiental, pode-se afirmar que esta é utilizada como instrumento de gestão no sentido que é por meio dela que os grupos conhecem a unidade. 
Por fim, é fundamental para um melhor aproveitamento da experiência o preparo dos professores que acompanham os alunos.

\section{BIBLIOGRAFIA}

BRASIL, Ministério do Meio Ambiente. Secretaria de Articulação Institucional e Cidadania Ambiental. Departamento de Educação Ambiental. Os diferentes matizes da educação ambiental no Brasil: 1997-2007. Brasília, DF: MMA, 2009. (Série Desafios da Educação Ambiental). 290 p.; 21 cm.

FERREIRA, L. F. Proposta de abordagem para a sensibilização ambiental: estudo de caso no centro educacional Polivalente. Monografia. Orientador: Ildeu Soares Martins. Co-Orientadora: Juliana Martins de Mesquita Matos. Universidade de Brasília. Brasília-DF, 2009.

GUIMARÃES, M. A Dimensão Ambiental na Educação. $8^{\text {a }}$ Edição, Papirus Editora. São Paulo, 2007.

MARCONDES, A. C. SOARES, P. A. de T. Curso básico de educação ambiental. Ed. Scipione, São Paulo. 1991.

MARTINS, A. P. Avaliação de metodologias de sensibilização ambiental como instrumento para a formação de multiplicadores ambientais no Parque Nacional de Brasília. Dissertação (mestrado) - Universidade de Brasília, Faculdade de Tecnologia, Programa de Pós-Graduação em Ciências Florestais. Brasília, 2013.

MENDES, M. V. Mudanças florísticas na vegetação lenhosa em Cerrado Sentido Restrito de vale na Estação Ecológica do Jardim Botânico de Brasília (2009-2013). Dissertação (Graduação) - Universidade de Brasília, Faculdade de Tecnologia. Graduação em Engenharia Florestal. Brasília, 2013.

MORIN, E. Os Sete Saberes necessários à Educação do Futuro. 2. ed. São Paulo: Cortez, 2000.

NELSON, S. P. Uso público nas unidades de conservação in Gestão das unidades de conservação: compartilhando uma experiência de capacitação. WWF-Brasil e IPEInstituto de Pesquisas Ecológicas. Maria Olatz Cases (Org.). Brasília, 2012.

PEDRINI, A. G, SAITO, C. H, (orgs.). Paradigmas metodológicos em Educação Ambiental. Petrópolis, RJ: Vozes, 2014.

Projeto Escola no Campo: Cerrado: Conhecer para cuidar. Hotel Fazenda Mestre D’Armas. Brasília, DF, 2005.

Sistema Nacional de Unidades de Conservação da Natureza - SNUC: Lei ํo 9.985, de 18 de julho de 2000; decreto $n^{\circ} 4.340$, de 22 de agosto de 2002. $6^{\circ}$ ed. Aum. Brasília: MMA/SBF, 2006. 56p. 
WEILER e HAM in WEAVER, D. (org). The encyclopedia of ecotourism. NYC: CABI, 2001.

Jardim Botânico de Brasília. Disponível em: http://www.jardimbotanico.df.gov.br/ 


\section{CONSIDERAÇÕES FINAIS}

A questão hídrica está fortemente relacionada com a criação do Jardim Botânico de Brasília, do Parque Nacional de Brasília e com a Estação Ecológica de Águas Emendadas, que cumprem a função de proteção deste recurso para o abastecimento de parte da população do Distrito Federal, além de beneficiar a sociedade promovendo os programas de educação ambiental direcionados para todo o tipo de público.

As respostas aos questionários aplicados às equipes de educação ambiental das unidades de conservação estudadas indicaram haver muito interesse e qualificação para o trabalho desenvolvido, existindo a preocupação em dar continuidade a esta qualificação, não se deixando abater pelas dificuldades enfrentadas para a realização dos projetos, que são bem estruturados, organizados e diversificados.

Todas as três unidades seguem, cada uma a seu modo, a mesma orientação quanto a educação ambiental: contextualizada socioambientalmente, emancipatória e crítica, promovida por meio de atividades teóricas e práticas de sensibilização quanto à questão ambiental visando uma mudança de comportamento raciocinada e permanente capaz de despertar cidadãos ativos em suas realidades.

Os trabalhos estão em conformidade com o conceito atual de EA, incluindo a vertente socioambiental no processo de aprendizagem fomentando a construção de um raciocínio sistêmico capaz de emancipar individualmente os participantes para exercer a cidadania, garantindo a boa educação na utilização de recursos naturais e equilíbrio dos sistemas.

As dificuldades apontadas pelas equipes, de uma forma geral, são muito parecidas, a clássica falta de recursos humanos e financeiros, não apenas para os programas de educação ambiental, mas também para a manutenção e funcionamento das UCs, que acabam funcionando por meio de improvisos, recursos dos próprios funcionários, doações, parcerias e trabalhos voluntários, que se mostraram indispensáveis à realização e continuidade dos programas.

Além da formação, a educação ambiental também é utilizada como instrumento de gestão ambiental para a sustentabilidade das unidades de uma forma geral, trabalhando não apenas com o público, para que respeitem e entendam estes locais, mas também com a população do entorno, como demonstrado no Programa do Parque Nacional de Brasília. Busca-se uma convivência harmoniosa preocupando-se em minimizar os inconvenientes para ambas as partes. Apesar deste ser um trabalho fundamental e 
permanente ele não substitui as obrigações governamentais quanto as áreas de protegidas.

Uma boa forma de incluir as unidades de conservação na sociedade é fazer divulgação de seus espaços e orientação quanto as diferentes formas de funcionamento, para que a população tome posse do que lhe pertence, cumprindo seus deveres e usufruindo de seus direitos. Outra forma seria haver um fundo de incentivo e apoio às unidades de conservação, ao invés deste ser diluído nos recursos para o meio ambiente.

Pode-se dizer que a maioria dos participantes desta pesquisa estava indo à unidade pela primeira vez, ainda sim apenas por ocasião da atividade escolar ou determinação judicial. Os próprios professores, no caso do Jardim Botânico, não apenas não conheciam o local que propuseram desenvolver um trabalho como demonstraram comportamento incompatível como, por exemplo, a intenção de coleta de material, evidenciando de forma clara a diferença entre os professores que participam de um programa como o Reeditor Ambiental antes de conduzirem uma turma de alunos, tendo objetivos definidos, orientando e instigando os alunos no decorrer do trabalho, aproveitando ao máximo o que é oferecido pelos profissionais e o potencial da turma.

No tocante ao trabalho com apenados ambientais desenvolvido pelo PNB, as atividades se mostraram adequadas, tanto as teóricas quanto as práticas, combatendo a principal argumentação de desconhecimento da legislação e sensibilizando quanto a importância de todo tipo de vida.

Em relação às crianças, o principal ponto observado, além do maior interesse pela fauna, foi à necessidade de se apresentar a origem dos produtos que são comumente utilizados por elas, de onde é retirada a matéria prima para a produção e quais os impactos que essa exploração gera, assim como as alternativas ao uso desses produtos, o descarte e sua real necessidade.

Somado a este tópico ainda vale o esclarecimento quanto as unidades de conservação de uma forma geral, a sua função, diferentes categoria (integral e uso sustentável), uso do espaço e outras informações úteis. Desta forma será possível a diferenciação entre área protegia e um parque, mas principalmente o comportamento adequado perante a estas áreas e a sua valorização.

Outro ponto foi o conhecimento quanto ao Cerrado que, apesar de ser o bioma no qual estão inseridos, demonstraram confusão em relação ao que é pertencente a ele e o que é próprio de outro bioma, no caso da fauna e flora, evidenciando a necessidade de uma campanha de conscientização e valorização do Cerrado. 
Para esta maior integração entre o meio natural e as pessoas a prática da percepção ambiental se mostra muito eficiente ao demonstrar como o ser humano é pertencente à natureza e que esta não é o meio hostil que pode-se pensar ou simplesmente uma reserva de recursos a ser explorada.

A metodologia NEPSO também se mostrou de grande valia para auxiliar na condução desta prática, uma vez que parte do interesse dos participantes, investigando como acontece a sua relação com o ambiente, utilizando estar informações de subsídio e envolvendo o público no desenvolvimento da atividade proposta.

Apesar dos objetivos deste trabalho não contemplarem uma investigação sobre a efetividade das políticas públicas para gestão de unidades de conservação, não se pode deixar de reparar que, apesar da existência de uma ampla legislação relacionada à educação ambiental, não se verificou a existência de ações governamentais de apoio para implementação dessas políticas. A partir disso pode-se inferir que os instrumentos de educação ambiental criados pelo governo não estão sendo aplicados nas suas próprias áreas de gestão.

\section{PERSPECTIVAS FUTURAS}

Sendo a educação ambiental um instrumento de gestão, para que a mesma funcione faz-se necessário articular e integrar os agentes envolvidos na sustentabilidade das unidades de conservação, sendo eles: a comunidade e os gestores da unidade. Esta articulação deve incluir também o trabalho com a Legislação pertinente, portanto são necessárias metodologias que viabilizem essa integração.

Devido a importância do preparo dos professores na condução das atividades seria extremamente interessante um estudo sobre os métodos para a qualificação e formas de motivar os professores a realizarem projetos continuados de natureza ambiental facilitando a inserção da temática nas rotinas escolares.

Afim de verificar a efetividade da metodologia utilizada recomenda-se a aplicação de questionário após os trabalhos de sensibilização para aferir a apropriação e a aprendizagem do conteúdo apresentado. 


\section{APÊNDICE A - QUESTIONÁRIO APLICADO AOS ALUNOS}

Cada questionário foi adaptado para a unidade de conservação em que foi aplicado, de forma que apenas o nome da unidade foi modificando, portanto será utilizado o modelo aplicado ao Jardim Botânico de Brasília como demonstrativo.

Este questionário foi aplicado aos alunos de escolas que agendaram visitas nas unidades de conservação. Importante ressaltar que o intuito deste é ter uma orientação da percepção das crianças à cerca do ambiente, sendo possível assinalar mais de uma resposta por questão.

1. Na sua opinião o Jardim Botânico é:

( ) Lugar ideal para visitação pública ( ) Uma área voltada para educação

( ) Lugar que serve para proteger a natureza ( ) Um espaço comum de lazer

2. Na sua opinião o Jardim Botânico existe porque:

( ) Ajuda a manter a qualidade de vida das pessoas

( ) Os animais e plantas tem que ter um espaço para viverem

( ) Ajuda na produção de água da região

( ) Alguém inventou para as pessoas terem onde se divertirem

3. Você visita o Jardim Botânico para:

( ) Ter contato com a Natureza

( ) Lazer

( ) Praticar esporte

( ) Sair da rotina

( ) Aproveitar o tempo livre com a família

( ) Aprender conteúdos escolares

( ) Outras:

4. Quais animais abaixo você pode ver no Cerrado?
( ) Lobo Guará
( ) Mico Leão dourado
( ) Tucano
( ) Golfinho
( ) Guepardo
( ) Carcará
( ) Urso
( ) Veado Campeiro
( ) Leão
( ) Tatu Canastra
( ) Ararinha azul
( ) Tamanduá 
5.São frutos do Cerrado:
( ) Laranja
( ) Jatobá
( ) Acerola
( ) Mangaba
( ) Limão
( ) Goiaba
( ) Banana
( ) Cagaita
( ) Araticum
( ) Pequi

6. Como proteger a natureza?

( ) Jogar lixo no lixo

( ) Desligando a torneira enquanto escova os dentes

( ) Apagar a luz ao sair do quarto

( ) Não comprar animais silvestres

( ) Não Jogar óleo na pia

( ) Denunciar queimadas

7. Por que é importante conservar as florestas?

( ) Porque as florestas são bonitas

( ) Porque os animais não vão ter onde morar

( ) Porque muitos remédios e alimentos são retirados das florestas

( ) Para podermos passear e fazer trilhas

( ) Porque as florestas ajudam a controlar o clima do planeta

8. Educação Ambiental é:

( ) Estudar a natureza

( ) Conhecer as plantas e os animais

( ) Aprender a agir corretamente em relação ao meio ambiente

( ) Perceber que minhas atitudes são importantes para ao meio ambiente

( ) Uma matéria que tenho que fazer na escola

9. São recursos da natureza que usamos:

( ) Água ( ) Solo ( ) Ar ( ) Vegetais ( ) Animais ( ) Petróleo ( ) Borracha

10. Você já conhecia o Jardim Botânico?

( ) Não ( ) Sim

11. Você já visitou algum outro parque?
( ) Não
( ) Sim Qual: 


\section{APÊNDICE B - QUESTIONÁRIO APLICADO À EQUIPE}

1. Qual a sua formação?

2. A quanto tempo trabalha no Jardim Botânico?

3. Qual a sua atuação dentro do programa de educação ambiental?

4. Houve/há algum treinamento para desenvolver esta atividade? 


\section{APÊNDICI C - QUESTIONÁRIO APLICADO AOS PROFESSORES}

1. Qual a dificuldade encontrada para aplicar a educação ambiental na sua escola?

( ) Não encontra apoio junto a diretoria ou outros professores

( ) Os alunos não demonstram interesse

( ) Não há verba disponível

( ) Não há espaço suficiente na escola

( ) O cronograma da escola não comporta

( ) Outros

\section{Qual a expectativa com o curso?}

( ) Compartilhar suas experiências e aprender com a dos outros

( ) Aprender formas de trabalhar a educação ambiental com os alunos

( ) Nenhuma, estou apenas cumprindo uma exigência

( ) Outros

3. Como pretende desenvolver a atividade de educação ambiental no espaço do Parque Nacional de Brasília?

( ) Utilizando as trilhas do parque

( ) Desenvolvendo atividade na piscina

( ) Um momento de lazer em contato com a natureza

( ) Não pretendo trazer os alunos para o parque

( ) Outros 